\title{
Vanuatu: Assessment of the Supervision and Regulation of the Financial Sector Volume II-Detailed Assessment of Observance of Standard and Codes
}

This detailed assessment of observance of standard and codes in the financial sector of Vanuatu in the context of the offshore financial center program contains technical advice and recommendations given by the staff team of the International Monetary Fund in response to the authorities of Vanuatu's request for technical assistance. It is based on the information available at the time it was completed on July 2003. The staff's overall assessment relating to financial sector regulation and supervision can be found in Volume I. The views expressed in these documents are those of the staff team and do not necessarily reflect the views of the government of Vanuatu or the Executive Board of the IMF.

The policy of publication of staff reports and other documents by the IMF allows for the deletion of market-sensitive information.

To assist the IMF in evaluating the publication policy, reader comments are invited and may be sent by e-mail to publicationpolicy@imf.org.

Copies of this report are available to the public from

International Monetary Fund $\bullet$ Publication Services

700 19th Street, N.W. • Washington, D.C. 20431

Telephone: (202) $6237430 \bullet$ Telefax: (202) 6237201

E-mail: publications@imf.org • Internet: http://www.imf.org

Price: $\$ 15.00$ a copy

\section{International Monetary Fund} Washington, D.C. 
ASSESSMENT OF THE SUPERVISION AND REgULATION OF THE FINANCIAL SECTOR

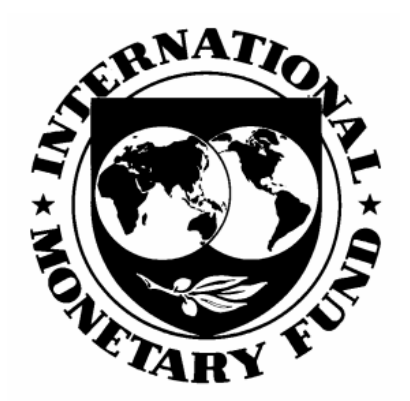

\section{Volume II: Detailed Assessment of Observance of Standards and Codes}

\section{Vanuatu}

July 2003 
"The contents of this report constitute technical advice and recommendations given by the staff of the International Monetary Fund (IMF) to the authorities of a member country in response to their request for technical assistance. With the written authorization of the recipient country's authorities, this report (in whole or in part) or summaries thereof may be disclosed to IMF Executive Directors and their staff, and to technical assistance providers and donors outside the IMF. Disclosure of this report (in whole or in part) or summaries thereof to parties outside the IMF other than technical assistance providers and donors shall require the written authorization of the recipient country's authorities and the IMF's Monetary and Financial Systems Department." 
I. Assessment of Compliance with the Basel Core Principles for Effective Banking

Supervision 4

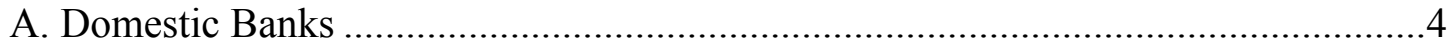

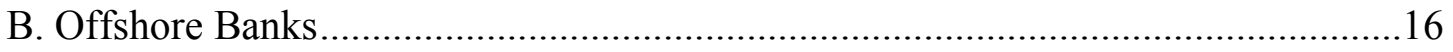

II. Assessment of the Observance of the IAIS Core Principles....................................29

III. Assessment of Legal, Institutional, and Supervisory Aspects of AML/CFT ...............43

Text Tables

1. Detailed Assessment with Compliance with the Basel Core Principles-Domestic

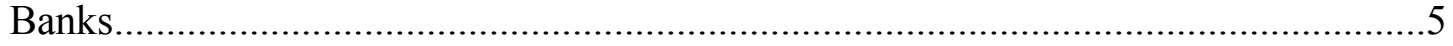

2. Summary Compliance with the Basel Core Principles-Domestic Banks .....................15

3. Detailed Assessment with Compliance with the Basel Core Principles-Offshore

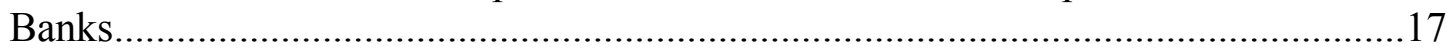

4. Summary Compliance with the Basel Core Principles - Offshore Banks .....................28

5. Detailed Assessment of Observance of the IAIS Insurance Core Principles...................30

6. Summary of Observance of International Association of Insurance Supervisors ...........43

7. Detailed Assessment of the Legal and Institutional AML/CFT Elements .....................45

8. Detailed Assessment of AML/CFT Core Criteria for Prudentially-Regulated Sectors ...54

9. Detailed Assessment of AML/CFT Sector-Specific Criteria for the Banking Sector .....59

10. Detailed Assessment of AML/CFT Sector-Specific Criteria for the Insurance .............61

11. Detailed Assessment of AML/CFT Elements for Other Service Providers ...................62

12. Summary of Compliance with AML/CFT Principles ..................................................64 


\section{Assessment of Compliance with the Basel Core Principles for EFFECTIVE BANKING SUPERVISION}

\section{A. Domestic Banks}

\section{General}

1. With the agreement of the Reserve Bank of Vanuatu (RBV), the mission assessed compliance with the Basel Core Principles for Effective Banking Supervision (BCP) using the Core Principles Methodology. The assessment was undertaken in the context of the Offshore Financial Center (OFC) Assessment Program, Module 2. The domestic and offshore sectors were subject to individual assessments, since they are covered by different legislation and supervised within different institutional frameworks. The assessment took place in May 2002, and was undertaken primarily by Mr. Richard Lang, a former Deputy Governor of the Reserve Bank of New Zealand, with the assistance of Mr. Richard Chalmers, mission chief. The resulting recommended action plan is contained in the appendix to Volume I of this report.

\section{Information and methodology used for assessment}

2. The assessment was based on a review of the applicable laws, regulations, and prudential guidelines (as detailed in Volume I), and discussions with staff of the RBV (primarily the deputy governor and staff of the banking supervision unit), industry groups (e.g., the bankers' and accountants' associations, and the finance center association), and representatives of individual financial institutions. More general background information was obtained from meetings with representatives of government ministries (e.g., ministry of finance and the State Law Office). Where relevant, a review was also undertaken of the RBV's internal procedures manuals, statistical and other reporting forms, policy notices (including drafts under preparation), and similar documentation. Prior to the mission, the RBV had responded to a questionnaire on the regulatory environment and had undertaken an informal review of its compliance with the core principles, but this did not constitute a formal self-assessment.

\section{Institutional and macroprudential setting, market structure-overview}

3. The RBV is responsible for the licensing and supervision of the domestic banking sector, while responsibility for the offshore banks falls to the Vanuatu Financial Services Commission (VFSC) (see separate detailed assessment). The RBV has a small banking supervision unit headed by the deputy governor. It carries out its responsibilities through a combination of routine off-site surveillance, based on a quarterly reporting system, and an on-site examination program.

4. The domestic banking sector comprises five commercial banks, including three branches and subsidiaries of Australian institutions; one government-owned institution; and a private bank; which, although it holds a domestic license, is not involved in the local market, but offers private banking facilities to nonresidents. The domestic license permits a universal banking operation, servicing both resident and nonresident customers, but the focus of the 
banks is primarily on traditional retail and commercial activities. The trend in recent years has been a gradual withdrawal of foreign banks from the domestic market, as institutions have sought to consolidate and to close their marginal operations. The total assets of the domestic banking system, as at end-2001, were \$345.6 million, of which about 40 percent comprised local assets, the balance representing almost entirely deposit placements overseas, mostly by the foreign banks with their respective parent banks. About 15 percent of the deposit base was sourced from nonresidents.

\section{Principle-by-principle assessment}

\section{Table 1. Detailed Assessment with Compliance with the Basel Core Principles-Domestic Banks}

\begin{tabular}{|c|c|}
\hline \multicolumn{2}{|c|}{$\begin{array}{l}\text { An effective system of banking supervision will have clear responsibilities and objectives for each agency } \\
\text { involved in the supervision of banks. Each such agency should possess operational independence and adequate } \\
\text { resources. A suitable legal framework for banking supervision is also necessary, including provisions relating to } \\
\text { the authorization of banking establishments and their ongoing supervision; powers to address compliance with } \\
\text { laws, as well as safety and soundness concerns; and legal protection for supervisors. Arrangements for sharing } \\
\text { information between supervisors and protecting the confidentiality of such information should be in place. }\end{array}$} \\
\hline \multirow{2}{*}{\multicolumn{2}{|c|}{$\begin{array}{l}\text { Principle 1(1) } \\
\text { An effective system of banking supervision will have clear responsibilities and objectives for each agency } \\
\text { involved in the supervision of banks. }\end{array}$}} \\
\hline & \\
\hline Description & $\begin{array}{l}\text { The RBV has supervisory responsibility for the supervision of domestic banks. The law } \\
\text { establishing the RBV came into effect in 1980. The Reserve Bank of Vanuatu Act provides that the } \\
\text { RBV shall have power, inter alia, to promote a sound financial structure and to regulate domestic } \\
\text { banks. } \\
\text { In 1999, the Financial Institutions Act was enacted. The Act states that it is the RBV's } \\
\text { responsibility to protect the banks' depositors. It confers a wide range of powers on the RBV, } \\
\text { including the power to issue and revoke banking licenses, conduct on-site examinations, request } \\
\text { data, place limits on the type and nature of business undertaken by banks, and issue prudential } \\
\text { guidelines. }\end{array}$ \\
\hline Asse & Materially noncompliant \\
\hline Comments & $\begin{array}{l}\text { There are no mechanisms to ensure consistent supervisory treatment of domestic and offshore } \\
\text { banks. Communications between the RBV and the VFSC (which supervises the offshore sector) are } \\
\text { informal and limited. While the law relating to domestic supervision is modern and generally } \\
\text { comprehensive, that applying to the offshore sector is outdated and inadequate. Difficulties will } \\
\text { continue until the latter issue is addressed. If the status quo in terms of having separate supervisors } \\
\text { for the two sectors is to continue, it is recommended that formal mechanisms be put in place to } \\
\text { improve communications. Consistency of treatment is not practical at present given the widely } \\
\text { different statutes under which the two supervisors operate. The optimum solution is to amalgamate } \\
\text { the supervisory authorities and, to the extent feasible, harmonize the legislation under which both } \\
\text { sectors are supervised. }\end{array}$ \\
\hline $\begin{array}{l}\text { Principle } \\
\text { 1(2) }\end{array}$ & Each such agency should possess operational independence and adequate resources. \\
\hline Description & $\begin{array}{l}\text { The Reserve Bank of Vanuatu Act provides for the RBV to have operational independence to issue } \\
\text { and revoke licenses as well as in the methods and processes it uses to carry out its supervisory } \\
\text { functions. The supervision function is funded from within the bank's income. The main constraint } \\
\text { on resources relates to experience and skills rather than finance. }\end{array}$ \\
\hline Assessment & Compliant \\
\hline Comments & ted. \\
\hline
\end{tabular}




\begin{tabular}{|c|c|}
\hline $\begin{array}{l}\text { Principle } \\
\text { 1(3) }\end{array}$ & $\begin{array}{l}\text { A suitable legal framework for banking supervision is also necessary, including provisions relating } \\
\text { to the authorization of banking establishments and their ongoing supervision. }\end{array}$ \\
\hline Description & $\begin{array}{l}\text { The Financial Institutions Act provides for the RBV to be solely responsible for the issuing } \\
\text { (Section } 12 \text { ) and revocation (Section } 17 \text { and } 46(3) \text { ) of domestic banking licenses and empowers the } \\
\text { Bank to set prudential rules (Part } 3 \text { ) that are not otherwise specified in legislation. The Act also } \\
\text { empowers the RBV to obtain information from banks in whatever form, at whatever frequency it } \\
\text { requires. The Act itself specifies minimum capital requirements (Vt } 200 \text { million) and maximum } \\
\text { levels for large exposures ( } 25 \text { percent of capital) and unsecured connected lending (Vt } 500,000 \text { or } 1 \\
\text { percent of capital). Banks are subject to a minimum liquidity requirement. At present the level has } \\
\text { been set at } 15 \text { percent by way of Prudential Guideline } 3 \text {. }\end{array}$ \\
\hline Assessment & Largely compliant \\
\hline Comments & $\begin{array}{l}\text { The specifications in the Financial Institutions Act relating to large exposures impose a constraint } \\
\text { on the RBV's capacity to set prudential rules, but it is not a material problem. When the Act is next } \\
\text { amended, it would be desirable to provide additional flexibility to the RBV to allow exceptions or } \\
\text { set institution-specific limits. }\end{array}$ \\
\hline $\begin{array}{l}\text { Principle } \\
\text { 1(4) }\end{array}$ & $\begin{array}{l}\text { A suitable legal framework for banking supervision is also necessary, including powers to address } \\
\text { compliance with laws, as well as safety and soundness concerns. }\end{array}$ \\
\hline Description & $\begin{array}{l}\text { Under both the Reserve Bank of Vanuatu Act and the Financial Institutions Act, the RBV is } \\
\text { provided with full powers to obtain information from banks to enable it to form a judgment as to } \\
\text { whether a bank is complying with its prudential requirements and has a number of options under } \\
\text { Part V of the Financial Institutions Act, including revocation of the license, to force a bank to take } \\
\text { remedial action, if that is thought necessary. While there was some questioning by some of the } \\
\text { banks of the powers of the RBV to view individual customer files, section } 28 \text { appears to provide } \\
\text { the necessary authority. }\end{array}$ \\
\hline Assessment & Compliant \\
\hline Comments & $\begin{array}{l}\text { At the next opportunity, it is recommended that it be made explicit in one or other of the acts that } \\
\text { section } 28 \text { of the Financial Institutions Act takes precedence over the provisions in the Companies } \\
\text { Act relating to secrecy. }\end{array}$ \\
\hline $\begin{array}{l}\text { Principle } \\
\text { 1(5) }\end{array}$ & $\begin{array}{l}\text { A suitable legal framework for banking supervision is also necessary, including legal protection } \\
\text { for supervisors. }\end{array}$ \\
\hline Description & $\begin{array}{l}\text { Section } 57 \text { of the Reserve Bank of Vanuatu Act provides legal protection to the RBV and its staff } \\
\text { while discharging their duties in good faith. }\end{array}$ \\
\hline Assessment & Largely compliant \\
\hline Comments & $\begin{array}{l}\text { It is not specified in the legislation that RBV staff would be protected for costs of defending any } \\
\text { action, but the RBV says that it would do so. This is an internal administrative issue and it is } \\
\text { recommended that the RBV issue a statement of policy to its staff. }\end{array}$ \\
\hline $\begin{array}{l}\text { Principle } \\
1(6)\end{array}$ & $\begin{array}{l}\text { Arrangements for sharing information between supervisors and protecting the confidentiality of } \\
\text { such information should be in place. }\end{array}$ \\
\hline Description & $\begin{array}{l}\text { The Financial Institutions Act provides that any information (statement, return, or information } \\
\text { provided by a licensee) that RBV has in its possession is to be regarded as confidential. Section } 55 \\
\text { requires that RBV, its staff, and any other appointed person must not disclose any information } \\
\text { acquired in the performance of their duties. However, disclosure can be made to a supervisory } \\
\text { authority in any other country to enable that supervisory authority to perform its supervisory duties, } \\
\text { provided that the RBV satisfies itself that the recipient of the information will maintain the } \\
\text { confidentiality. The RBV has the right to deny any demand for information held in respect of } \\
\text { licensees other than in response to a court order or another piece of legislation, e.g., the Financial } \\
\text { Transactions Reporting Act, which deals with money laundering. }\end{array}$ \\
\hline Assessment & Compliant \\
\hline Comments & \\
\hline \multicolumn{2}{|c|}{ Principle 2. Permissible Activities } \\
\hline
\end{tabular}




\begin{tabular}{|c|c|}
\hline & $\begin{array}{l}\text { A person is taken to be carrying on banking business if the person: } \\
\text { (a) advertises for or solicits deposits of money, or offers to sell or place bonds, certificates, } \\
\text { notes, or other securities; and } \\
\text { (b) uses or intends to use the funds so acquired, either in whole or in part, for making loans or } \\
\text { investments, or any other activity authorized by law or customary banking practice, for the } \\
\text { account and at the risk of the person advertising, soliciting or making offers. } \\
\text { In addition, the Act allows that any other financial activity approved in writing by a licensee may } \\
\text { be deemed to be banking business. } \\
\text { Under section } 7 \text {, only a licensed bank may have the word "bank" in its title or describe itself as a } \\
\text { bank. Section } 61 \text { of the Financial Institutions Act also provides for restrictions on the use of the } \\
\text { word "bank." }\end{array}$ \\
\hline & Largely compliant \\
\hline & $\begin{array}{l}\text { A small number of insignificant financial institutions, mainly cooperative societies that take } \\
\text { deposits, are not directly supervised. Should the unsupervised sector become of any significance, } \\
\text { action will be required to bring them into the full supervisory net. Section } 5(3) \text { of the Financial } \\
\text { Institutions Act provides for nonbank financial institutions (such as credit unions) to be supervised } \\
\text { by the RBV if their assets exceed a threshold (Vt } 10 \text { million). }\end{array}$ \\
\hline \multicolumn{2}{|c|}{$\begin{array}{l}\text { Principle 3. Licensing Criteria } \\
\text { The licensing authority must have the right to set criteria and reject applications for establishments that do not } \\
\text { meet the standards set. The licensing process, at a minimum, should consist of an assessment of the banking } \\
\text { organization's ownership structure, directors, and senior management, its operating plan and internal controls, and } \\
\text { its projected financial condition, including its capital base; where the proposed owner or parent organization is a } \\
\text { foreign bank, the prior consent of its home country supervisor should be obtained. }\end{array}$} \\
\hline Description & $\begin{array}{l}\text { The Reserve Bank of Vanuatu Act (Part } 2 \text { Division 2) and the actual practice of the RBV are fully } \\
\text { consistent with the above description. However, practice is to some extent untested in that, since } \\
\text { the present legislation was implemented, only one application has been received and that was } \\
\text { rejected. }\end{array}$ \\
\hline & \\
\hline & \\
\hline \multicolumn{2}{|c|}{$\begin{array}{l}\text { Principle 4. Ownership } \\
\text { Banking supervisors must have the authority to review and reject any proposals to transfer significant ownership } \\
\text { or controlling interests in existing banks to other parties. }\end{array}$} \\
\hline Description & $\begin{array}{l}\text { Section } 51 \text { of the Financial Institutions Act provides that a domestic licensee must obtain the } \\
\text { written approval of the RBV before it carries out a specified event that will result in a person } \\
\text { acquiring, or exercising power over, } 20 \text { percent or more of the voting stock of the licensee. This } \\
\text { includes the sale, transfer, or any other disposition of a licensee's share capital, or the issue of }\end{array}$ \\
\hline
\end{tabular}




\begin{tabular}{|c|c|}
\hline & $\begin{array}{l}\text { otment of any new share capital. A person who disposes of any shares of a licensee must notify } \\
\text { licensee of the disposal, if it would constitute a specified event. }\end{array}$ \\
\hline Assessment & rgely compliant \\
\hline Comments & $\begin{array}{l}\text { It is open to question whether, from a practical perspective, section } 51 \text { is legally enforceable as the } \\
\text { licensed institution itself cannot control the actions of its shareholders. This particularly applies to } \\
\text { the Australian-owned banks where the local branches/subsidiaries are unlikely to be consulted or } \\
\text { even advised in advance of any changes of ownership. Nevertheless, if the RBV was not satisfied } \\
\text { that the new owners were fit-and-proper persons, it would have the power to revoke the banks } \\
\text { license to operate in Vanuatu. Hence, the intent of the principle is met. }\end{array}$ \\
\hline \multicolumn{2}{|c|}{$\begin{array}{l}\text { Principle 5. Investment Criteria } \\
\text { Banking supervisors must have the authority to establish criteria for reviewing major acquisitions or investments } \\
\text { by a bank and ensuring that corporate affiliations or structures do not expose the bank to undue risks or hinder } \\
\text { effective supervision. }\end{array}$} \\
\hline Description & $\begin{array}{l}\text { The prior approval of the RBV is required under section } 50 \text { of the Financial Institutions Act before } \\
\text { a licensee undertakes a major acquisition or investment. In addition, Section } 35 \text { and Prudential } \\
\text { Guideline } 6 \text { place restrictions on the size of investments that can be undertaken by banks. The RBV } \\
\text { reviews the impact on the licensee's capital structure, how the acquisition would be managed and } \\
\text { the integration timetable, if the board of the bank has approved the transaction and the price to be } \\
\text { paid. As part of the process the RBV asks to be provided with copies of internal papers and would } \\
\text { normally meet with the management to understand the strategic fit of the acquisition/investment. It } \\
\text { would be expected that any major acquisition or investment would be made in the field of finance. }\end{array}$ \\
\hline Asse: & \\
\hline & \\
\hline \multicolumn{2}{|c|}{$\begin{array}{l}\text { Principle 6. Capital Adequacy } \\
\text { Banking supervisors must set minimum capital adequacy requirements for banks that reflect the risks that the bank } \\
\text { undertakes, and must define the components of capital, bearing in mind its ability to absorb losses. For } \\
\text { internationally active banks, these requirements must not be less than those established in the Basel Capital } \\
\text { Accord. }\end{array}$} \\
\hline Description & $\begin{array}{l}\text { Section } 31 \text { of the Reserve Bank of Vanuatu Act provides that a domestic licensee must maintain at } \\
\text { all times capital in such minimum proportion in relation to its assets, liabilities or risk exposures, } \\
\text { and in such amount as the RBV specifies from time to time. } \\
\text { Under Section 14, the start-up capital for a bank is Vt } 200 \text { million. This is the minimum but the } \\
\text { RBV has the discretion to set higher initial capital requirement. } \\
\text { In addition to the requirements of the act, in } 1999 \text { the RBV issued a capital adequacy guideline. } \\
\text { Prudential Guideline } 4 \text { describes the approach used by the RBV for assessing the capital adequacy } \\
\text { of Vanuatu banks (and their consolidated groups). While off-balance sheet risks are included } \\
\text { presently, no provision is made for market risks. } \\
\text { Under the guideline, capital is considered in two tiers. Tier } 1 \text { (or core capital) comprises the highest } \\
\text { quality capital elements. Tier } 2 \text { (or supplementary capital) represents other elements, which do not } \\
\text { satisfy all of the characteristics of Tier } 1 \text { capital but which contribute to the overall strength of a } \\
\text { bank as a going concern. Banks are required to maintain a minimum capital adequacy ratio of } \\
\text { capital to risk-weighted assets, on both a consolidated group and stand-alone basis of } 8 \text { percent, of } \\
\text { which at least } 4 \text { percent must be Tier } 1 \text { capital. }\end{array}$ \\
\hline & Large \\
\hline Com & $\begin{array}{l}\text { No provision is made for market risk. At present the exposure of the Vanuatu banks to market risk } \\
\text { is negligible, but for sake of completeness at some stage it would be desirable to incorporate it in } \\
\text { the calculation. }\end{array}$ \\
\hline \multicolumn{2}{|c|}{$\begin{array}{l}\text { Principle 7. Credit Policies } \\
\text { An essential part of any supervisory system is the independent evaluation of a bank's policies, practices, and } \\
\text { procedures related to the granting of loans and making of investments and the ongoing management of the loan } \\
\text { and investment portfolios. }\end{array}$} \\
\hline
\end{tabular}




\begin{tabular}{|c|c|}
\hline Description & $\begin{array}{l}\text { The RBV has issued a policy guideline on loan classification and provisioning for impaired assets. } \\
\text { However, where banks operate in Vanuatu as branches and subsidiaries of international banks, and } \\
\text { have in place systems mandated by the parent that are compatible with the RBV's minimum } \\
\text { approach, they are permitted to follow their group systems. In cases where the banks do not have } \\
\text { their own systems in place, the RBV's guideline (No. 2) must be applied. } \\
\text { In general, the guideline requires the banks to have a system in place that will classify lending } \\
\text { assets into standard, substandard, doubtful, and loss. } \\
\text { Banks are required to maintain a prudent level of general provisions against losses not as yet } \\
\text { identified on the good quality part of the loan portfolio and specific provisions against reasonably } \\
\text { anticipated losses on poor quality assets and all specifically identified losses on impaired assets. } \\
\text { On-site examinations concentrate on this area. }\end{array}$ \\
\hline Asse & Compliant \\
\hline Comr & \\
\hline \multicolumn{2}{|c|}{$\begin{array}{l}\text { Principle 8. Loan Evaluation and Loan-Loss Provisioning } \\
\text { Banking supervisors must be satisfied that banks establish and adhere to adequate policies, practices, and } \\
\text { procedures for evaluating the quality of assets and the adequacy of loan-loss provisions and reserves. }\end{array}$} \\
\hline Descr & $\begin{array}{l}\text { The RBV has the power to recommend that a bank increase provision levels if any under- } \\
\text { assessment of the level of provisions required may result in a bank's capital and profits being } \\
\text { overstated and could lead to a lack of certainty about the bank's ongoing solvency. } \\
\text { General provisions for possible losses, which are not associated with an identifiable asset or } \\
\text { amount, are required to be maintained at prudent levels by each bank. For this purpose, the RBV } \\
\text { may require } 1 \text { percent of the outstanding balance of all facilities classified as "standard" to be } \\
\text { allocated to the general provision. } \\
\text { In the case of branches of foreign financial institutions, the RBV may require written confirmation } \\
\text { from the head office, where an institution has advised that the general provision is maintained in } \\
\text { the head office's books to cover the Vanuatu operations. } \\
\text { If a bank does not have a risk-grading system or portfolio review system then the RBV requires it } \\
\text { to establish provisions, which are not less than the sum of the following: } \\
\text { - } 20 \text { percent of the outstanding balance of all facilities classified as substandard (which may } \\
\text { be established as an unallocated specific provision); } \\
\quad 50 \text { percent of the outstanding balance of all facilities classified as doubtful, as an allocated } \\
\text { specific provision; } \\
\quad 100 \text { percent of the outstanding balance of all facilities classified as loss (unless already } \\
\text { written off in full) as an allocated specific provision. } \\
\text { - } \\
\text { le directives have been issued with respect to how regularly they review their asset quality. That is } \\
\text { left to bank management, although the bank's policies are monitored by the RBV. Banks are } \\
\text { required to report quarterly on asset quality. } \\
\text { This is a priority area for on-site examinations. }\end{array}$ \\
\hline Asses & Compliant \\
\hline Comments & \\
\hline Principle 9. & arge Exposure Limits \\
\hline
\end{tabular}




\begin{tabular}{|c|c|}
\hline Description & $\begin{array}{l}\text { Section } 38 \text { of the Reserve Bank of Vanuatu Act provides that a licensee must not make any } \\
\text { advances or credit facility to any person or body (whether corporate or unincorporated), or any } \\
\text { group of bodies that is under the control of a particular individual (who holds or has the power to } \\
\text { vote for, at least, } 51 \text { percent of the voting shares) exceeding } 25 \text { percent of its capital. } \\
\text { Exposures include claims and commitments recorded both on and off the balance sheet of a bank } \\
\text { on a consolidated group basis. In addition to the requirements of Section } 38(2) \text {, the RBV's } \\
\text { Prudential Guideline } 8 \text { requires that a bank should treat counterparties as related where they are } \\
\text { linked by cross guarantees, common ownership, ability to control financial interdependency, or } \\
\text { other connections which, in the bank's assessment, identify the counterparties as representing a } \\
\text { single risk. } \\
\text { As part of the licensing requirements, the applicants' proposed internal risk management systems } \\
\text { are assessed. In addition prudential guideline on credit risk management which requires that banks } \\
\text { need to have in place management information systems in order to track portfolio diversification } \\
\text { characteristics. Each bank needs to have in place a system to enable credits to be grouped by single } \\
\text { and associated groups of counterparties, types of credit facilities, and industries. On-site inspections } \\
\text { provide ongoing monitoring. }\end{array}$ \\
\hline Assessment & Compliant \\
\hline $\begin{array}{l}\text { Comments } \\
\text { Principle } 1 \\
\text { In order to } \\
\text { that banks } 1 \\
\text { effectively }\end{array}$ & $\begin{array}{l}\text { related companies and individuals on an arm's-length basis, that such extensions of credit are } \\
\text { ored, and that other appropriate steps are taken to control or mitigate the risks. }\end{array}$ \\
\hline Description & $\begin{array}{l}\text { Section } 39 \text { of the Financial Institutions Act prohibits banks from extending on an unsecured basis } \\
\text { any facility (including a guarantee) in excess of Vt } 500,000 \text { or } 1 \text { percent of capital (whichever is the } \\
\text { greater) to related parties, as defined, (including, directors, family, and business interests). Under } \\
\text { Section } 40 \text { of the act, banks must extend facilities to related parties on substantially the same terms } \\
\text { as they would for the general public. Advances to parties related to the bank are subject to the } \\
\text { requirements of Section } 38 \text { (Restrictions on Advances Exceeding } 25 \text { percent of Capital). } \\
\text { In addition, under Prudential Guideline } 7 \text {-Dealings with Subsidiaries and Associates - a bank } \\
\text { may not give a general guarantee of the obligations of a subsidiary or associate. A bank must } \\
\text { address its risk exposures arising from financial dealings with subsidiaries and associates } \\
\text { (including transactions between a foreign bank and its Vanuatu subsidiaries and associates) as } \\
\text { strictly as it would address its risk exposures to unrelated entities. } \\
\text { Banks are required to establish prudent limits on exposures to these entities at both an individual } \\
\text { and an aggregate level. In determining limits on acceptable levels of exposure to subsidiaries and } \\
\text { associates, a bank must have regard for: } \\
\text { (a) } \\
\text { the level of exposures that would be approved for unrelated entities of similar credit status; } \\
\text { and } \\
\text { the impact on the bank's capital and liquidity positions, as well as its ability to continue } \\
\text { operating, in the event of a failure of any of these entities to which the bank is exposed. } \\
\text { (b) } \\
\text { - } \\
\text { The Act defines a body corporate as an affiliate of another body corporate if: } \\
\text { either body corporate holds not less than } 20 \text { percent but not more than } 50 \text { percent of the } \\
\text { outstanding voting stock of the other body corporate; or } \\
\text { ofther body corporate. }\end{array}$ \\
\hline
\end{tabular}




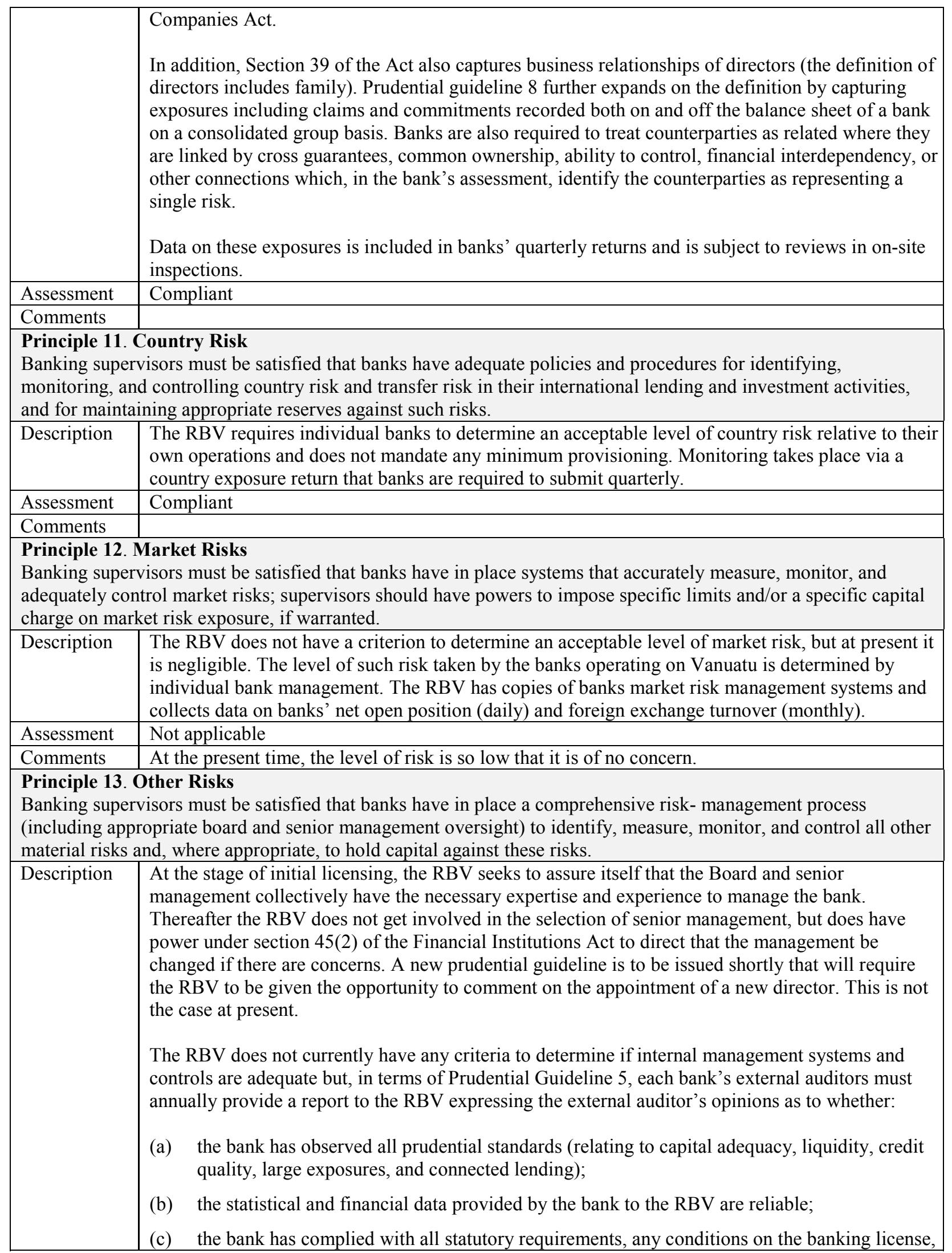




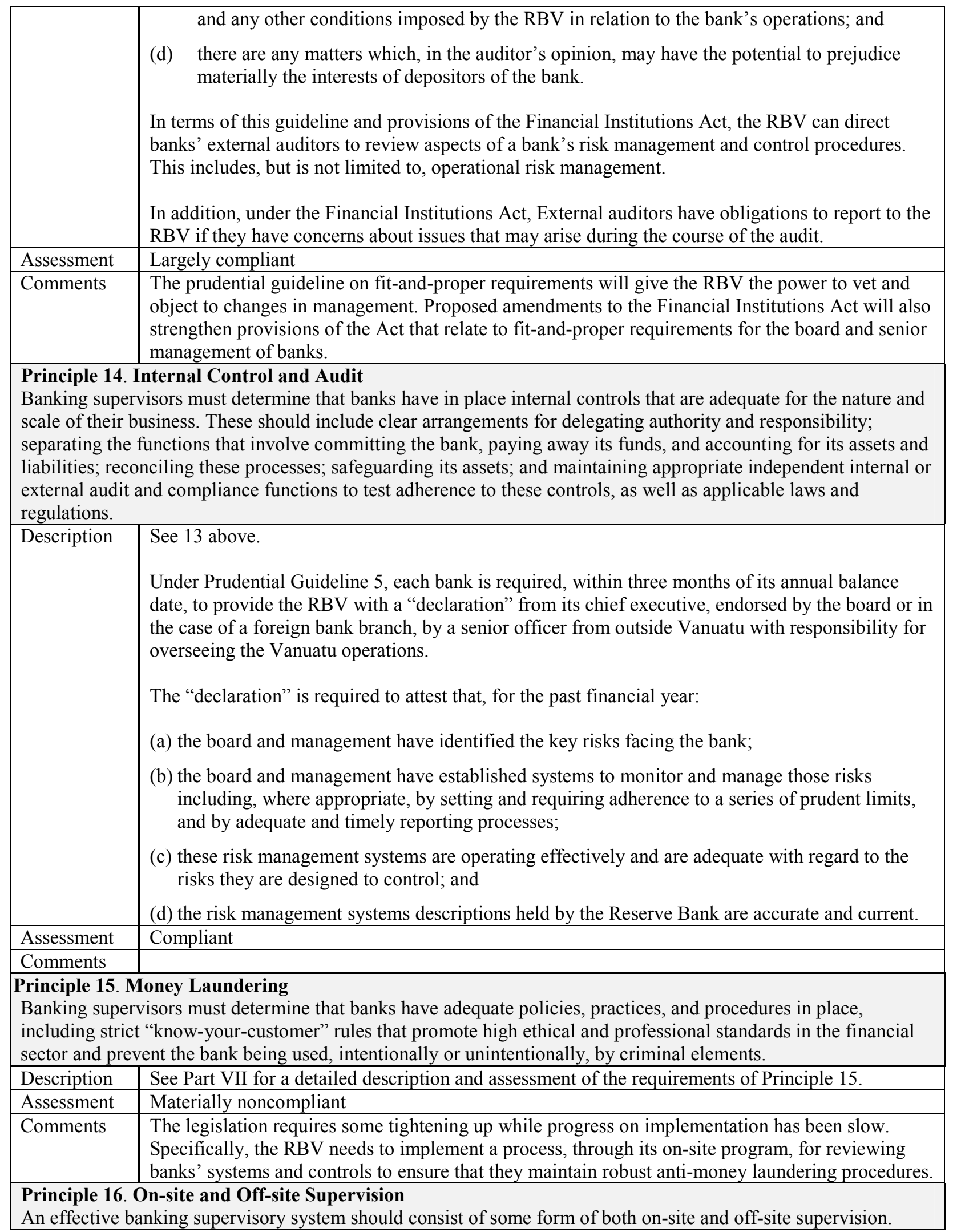




\begin{tabular}{|c|c|}
\hline Description & $\begin{array}{l}\text { The RBV conducts off-site and on-site supervision under authorizations contained in Part } 3 \text { of the } \\
\text { Financial Institutions Act. } \\
\text { Off-site supervision involves the analysis from the various returns of capital adequacy, } \\
\text { profitability, asset quality, and changes in balance sheet, asset concentrations, large exposures and } \\
\text { deposit concentrations, and a range of other data. } \\
\text { On-site inspections to date have been confined to reviewing bank's credit risk management } \\
\text { systems. Prior to conducting a review, the RBV asks for a sample of various files to be made } \\
\text { available, and then selects files to be reviewed from this sample. These files are selected by the } \\
\text { RBV and cover all areas of banks' portfolio, including its impaired assets. The aim of the visits is } \\
\text { to assess how the bank's systems operate and to gain a better understanding of the bank's approach } \\
\text { to risk. The reviews do not aim to review credit decisions other than to ensure that they are } \\
\text { consistent with the policy framework. On-site reviews are undertaken about every } 24 \text { months. }\end{array}$ \\
\hline Assessment & Compliant \\
\hline \multicolumn{2}{|l|}{ Comments } \\
\hline \multicolumn{2}{|c|}{$\begin{array}{l}\text { Principle 17. Bank Management Contact } \\
\text { Banking supervisors must have regular contact with bank management and a thorough understanding of the } \\
\text { institution's operations. }\end{array}$} \\
\hline Description & $\begin{array}{l}\text { In addition to the on-site inspections, the RBV holds formal annual meetings with each bank's } \\
\text { senior management to discuss strategy, developments in risk-management systems, issues arising } \\
\text { from audit and other reports, and the various prudential returns. In addition, with only four banks } \\
\text { involved and the relative smallness of Vila, inevitably there is a large amount of informal contact } \\
\text { with the banks' senior management, both individually and collectively. }\end{array}$ \\
\hline Assessment & Compliant \\
\hline \multicolumn{2}{|l|}{ Comments } \\
\hline \multicolumn{2}{|c|}{$\begin{array}{l}\text { Principle 18. Off-site Supervision } \\
\text { Banking supervisors must have a me }\end{array}$} \\
\hline Description & $\begin{array}{l}\text { None of the four banks has any subsidiary companies or offshore operations. As noted above, the } \\
\text { RBV has adequate powers and resources to collect and analyze the various reports and statistical } \\
\text { returns received from the banks. }\end{array}$ \\
\hline Assessment & Compliant \\
\hline \multicolumn{2}{|l|}{ Comments } \\
\hline \multicolumn{2}{|c|}{$\begin{array}{l}\text { Principle 19. Validation of Supervisory Information } \\
\text { Banking supervisors must have a means of independent validation of supervisory information either through on- } \\
\text { site examinations or use of external auditors. }\end{array}$} \\
\hline Description & $\begin{array}{l}\text { Prudential guideline } 5 \text { provides for each bank's external auditors to report annually on the } \\
\text { reliability of the supervisory information submitted. See } 13 \text { above. } \\
\text { The appointment of a new external auditor requires the approval of the RBV but there is no explicit } \\
\text { provision that would enable the RBV to demand a change of external auditors. Under section } 25 \text { of } \\
\text { the Financial Institutions Act, the RBV has the power to appoint an external auditor or other person } \\
\text { to prepare a report for the RBV on such matters as it may determine. }\end{array}$ \\
\hline Assessment & Compliant \\
\hline Comments & \\
\hline \multicolumn{2}{|c|}{$\begin{array}{l}\text { Principle 20. Consolidated Supervision } \\
\text { An essential element of banking supervision is the ability of the supervisors to supervise the banking group on a } \\
\text { consolidated basis. }\end{array}$} \\
\hline Description & $\begin{array}{l}\text { Once the two ANZ Bank subsidiaries are merged, none of the four banks will have any subsidiary } \\
\text { companies. Should that change, there are adequate powers to require consolidated supervision. }\end{array}$ \\
\hline Assessment & Compliant \\
\hline Comments & $\begin{array}{l}\text { If consolidated supervision becomes necessary, some additional training of the supervisory staff } \\
\text { will be required. }\end{array}$ \\
\hline
\end{tabular}




\begin{tabular}{|c|c|}
\hline \multicolumn{2}{|c|}{ Principle 21. Accounting Standards } \\
\hline Description & $\begin{array}{l}\text { There is no specific provision covering accounting standards, but banks are required to submit } \\
\text { annual accounts audited by a RBV approved auditor. RBV policy is to approve only qualified } \\
\text { chartered accountants (or their firms) as auditors and, in accordance with their professional bodies } \\
\text { regulations, the auditors would have to tag any accounts that were not drawn up in accordance with } \\
\text { international General Accounting Principles. In the unlikely event of the accounts being so tagged, } \\
\text { the RBV could issue an appropriate directive. }\end{array}$ \\
\hline Assessment & Compliant \\
\hline \\
\hline \multicolumn{2}{|c|}{$\begin{array}{l}\text { Principle 22. Remedial Measures } \\
\text { Banking supervisors must have at their disposal adequate supervisory measures to bring about timely corrective } \\
\text { action when banks fail to meet prudential requirements (such as minimum capital adequacy ratios), when there are } \\
\text { regulatory violations, or where depositors are threatened in any other way. In extreme circumstances, this should } \\
\text { include the ability to revoke the banking license or recommend its revocation. }\end{array}$} \\
\hline Description & $\begin{array}{l}\text { Under the Financial Institutions Act, there is a wide range of sanctions available to the RBV. Fines } \\
\text { can be imposed on institutions failing to comply with directives or to meet requirements of the act. } \\
\text { In addition, institutions can be required to hold additional capital above the required minimum if } \\
\text { the RBV consider that the bank's risk profile justifies such a requirement. In the extreme, the RBV } \\
\text { can revoke a license if it is of the view that the interests of depositors are being jeopardized. Prior } \\
\text { to this, in terms of Section } 45 \text { of the act, the RBV can issue a directive to the licensee, including the } \\
\text { replacement of management. } \\
\text { The offences provisions in the Financial Institutions Act apply to 'persons' who are defined to } \\
\text { include both individuals and corporate bodies. Since the present Act was passed, these powers have } \\
\text { not been used. }\end{array}$ \\
\hline Assessment & \\
\hline Comments & \\
\hline \multicolumn{2}{|c|}{$\begin{array}{l}\text { Banking supervisors must practice global consolidated supervision over their internationally active banking } \\
\text { organizations, adequately monitoring and applying appropriate prudential norms to all aspects of the business } \\
\text { conducted by these banking organizations worldwide, primarily at their foreign branches, joint ventures, and } \\
\text { subsidiaries. }\end{array}$} \\
\hline Description & The licensed banks do not have any offshore branches or subsidiaries. \\
\hline Assessment & \\
\hline \multicolumn{2}{|l|}{ Comments } \\
\hline \multicolumn{2}{|c|}{$\begin{array}{l}\text { Principle 24. Host Country Supervision } \\
\text { A key component of consolidated supervision is establishing contact and information exchange with the various } \\
\text { other supervisors involved, primarily host country supervisory authorities. }\end{array}$} \\
\hline Description & $\begin{array}{l}\text { The RBV is host supervisor for the Australian banks operating in Vanuatu and it has regular } \\
\text { contact and shares information with the relevant Australian supervisory authority. }\end{array}$ \\
\hline Assessment & Compliant \\
\hline Comments & \\
\hline \multicolumn{2}{|c|}{$\begin{array}{l}\text { Principle 25. Supervision over Foreign Banks' Establishments } \\
\text { Banking supervisors must require the local operations of foreign banks to be conducted with the same high } \\
\text { standards as are required of domestic institutions and must have powers to share information needed by the home } \\
\text { country supervisors of those banks for the purpose of carrying out consolidated supervision. }\end{array}$} \\
\hline Description & $\begin{array}{l}\text { With the exception of slightly different rules relating to capital adequacy and large and connected } \\
\text { exposures for Westpac, which reflect its local status as a branch, supervision rules and processes } \\
\text { are the same for all domestic licensed banks. }\end{array}$ \\
\hline
\end{tabular}




\begin{tabular}{|l|l|}
\hline & $\begin{array}{l}\text { Contacts are maintained with other supervisors and section 55(3) (c) of the Financial Institutions } \\
\text { Act provides authority for the RBV to share information with them. }\end{array}$ \\
\hline Assessment & Compliant \\
\hline Comments & \\
\hline
\end{tabular}

Table 2. Summary Compliance with the Basel Core Principles-Domestic Banks

\begin{tabular}{|l|c|c|c|c|c|}
\hline \multicolumn{1}{|c|}{ Core Principle } & $\mathrm{C}^{\mathrm{I} /}$ & $\mathrm{LC}^{2 /}$ & $\mathrm{MNC}^{3 /}$ & $\mathrm{NC}^{4 /}$ & $\mathrm{NA}^{5 /}$ \\
\hline 1. Objectives, Autonomy, Powers, and Resources & & & & & \\
\hline 1.1 Objectives & & & $\mathbf{X}$ & & \\
\hline 1.2 Independence & $\mathbf{X}$ & & & & \\
\hline 1.3 Legal framework & $\mathbf{X}$ & $\mathbf{X}$ & & & \\
\hline 1.4 Enforcement powers & & $\mathbf{X}$ & & & \\
\hline 1.5 Legal protection & $\mathbf{X}$ & & & & \\
\hline 1.6 Information sharing & & $\mathbf{X}$ & & & \\
\hline 2. Permissible activities & $\mathbf{X}$ & & & & \\
\hline 3. Licensing criteria & & $\mathbf{X}$ & & & \\
\hline 4. Ownership & $\mathbf{X}$ & & & & \\
\hline 5. Investment criteria & & $\mathbf{X}$ & & & \\
\hline 6. Capital adequacy & $\mathbf{X}$ & & & & \\
\hline 7. Credit policies & $\mathbf{X}$ & & & & \\
\hline 8. Loan evaluation and loan-loss provisioning & $\mathbf{X}$ & & & & \\
\hline 9. Large exposure limits & $\mathbf{X}$ & & & & \\
\hline 10. Connected lending & $\mathbf{X}$ & & & & \\
\hline 11. Country risk & & & & & $\mathbf{X}$ \\
\hline 12. Market risks & & $\mathbf{X}$ & & & \\
\hline 13. Other risks & $\mathbf{X}$ & & & & \\
\hline 14. Internal control and audit & & & $\mathbf{X}$ & & \\
\hline 15. Money laundering & $\mathbf{X}$ & & & & \\
\hline 16. On-site and off-site supervision & $\mathbf{X}$ & & & & \\
\hline 17. Bank management contact & $\mathbf{X}$ & & & & \\
\hline 18. Off-site supervision & $\mathbf{X}$ & & & & \\
\hline 19. Validation of supervisory information & $\mathbf{X}$ & & & & \\
\hline 20. Consolidated supervision & $\mathbf{X}$ & & & & \\
\hline 21. Accounting standards & $\mathbf{X}$ & & & & \\
\hline 22. Remedial measures & $\mathbf{X}$ & & & & \\
\hline 23. Global consolidated supervision & & & & \\
\hline 24. Host country supervision & & & \\
\hline $\begin{array}{l}\text { 25. Supervision over foreign banks } \\
\text { establishments }\end{array}$ & & & & \\
\hline
\end{tabular}

1/ Compliant.

2/ Largely compliant.

$\underline{3}$ / Materially noncompliant.

$\underline{4}$ / Noncompliant.

$\underline{5}$ / Not applicable. 


\section{B. Offshore Banks}

\section{General}

5. With the agreement of the VFSC, the mission assessed compliance with the Basel Core Principles for Effective Banking Supervision for the offshore sector, using the Core Principles Methodology. The assessment was undertaken in the context of the OFC Assessment Program, Module 2. The domestic and offshore sectors were subject to individual assessments, since they are covered by different legislation and supervised within different institutional frameworks. The assessment took place in May 2002 and was undertaken by Richard Chalmers, mission head, and Richard Lang, a former deputy governor of the Reserve Bank of New Zealand. The resulting recommended action plan is contained in the appendix to Volume I of this report.

\section{Information and methodology used for assessment}

6. The assessment was based on a review of the applicable laws, regulations and policy statements issued by the VFSC (as detailed in Volume I) and discussions with the chairman and staff of the VFSC (primarily the commissioner and banking supervisors), the RBV (the deputy governor and banking supervision unit), industry groups (e.g., the Finance Center Association and associations representing the accountants and lawyers), and representatives of individual institutions that provide services to the offshore banking sector. More general background information was obtained from meetings with representatives of government ministries (e.g., ministry of finance and the State Law Office). The near-complete absence of any offshore banks with a physical presence in Vanuatu prevented any direct discussion with the banks themselves. Where available, note was also taken of the VFSC's statistical reporting and other forms, policy statements issued to the industry, internal guidance memoranda and other similar documentation. Prior to the mission, the VFSC had submitted a response to a detailed questionnaire, but had not undertaken a formal self-assessment.

\section{Institutional and macroprudential setting, market structure—overview}

7. The VFSC is responsible for the ongoing supervision of the offshore banking sector, but the minister of finance retains responsibility for licensing and the exercise of enforcement powers. The supervisory processes employed by the VFSC are relatively underdeveloped and are largely based upon the receipt and review of quarterly financial returns.

8. The offshore banking sector consists of 34 licensed banks, of which only 3 have a real physical presence in Vanuatu. The remaining are "shell banks" with no presence beyond either a resident "nominee" director or resident agent who acts mainly as a service address. All 34 are prohibited from undertaking business with Vanuatu residents, while those licensed since 1993 are also restricted, under a general condition of their license, from soliciting funds from the public in any jurisdiction. They may however, take deposits from associated and non-associated persons provided they do not publicly advertise for deposits. Total known assets of the 34 banks as at December 2001, were approximately $\$ 2.4$ billion, of which $\$ 1.8$ billion were recorded as market-related instruments and investments. 
9. The authorities have very little information on the nature of the business of the offshore banks, but some are believed to be in-house treasuries for trading conglomerates. The mission was informed that the others are understood to be mainly associated with financial sector groups and are used principally to facilitate tax avoidance and/or asset protection schemes for themselves and their clients.

\section{Principle-by-principle assessment}

\section{Table 3. Detailed Assessment with Compliance with the Basel Core Principles-} Offshore Banks

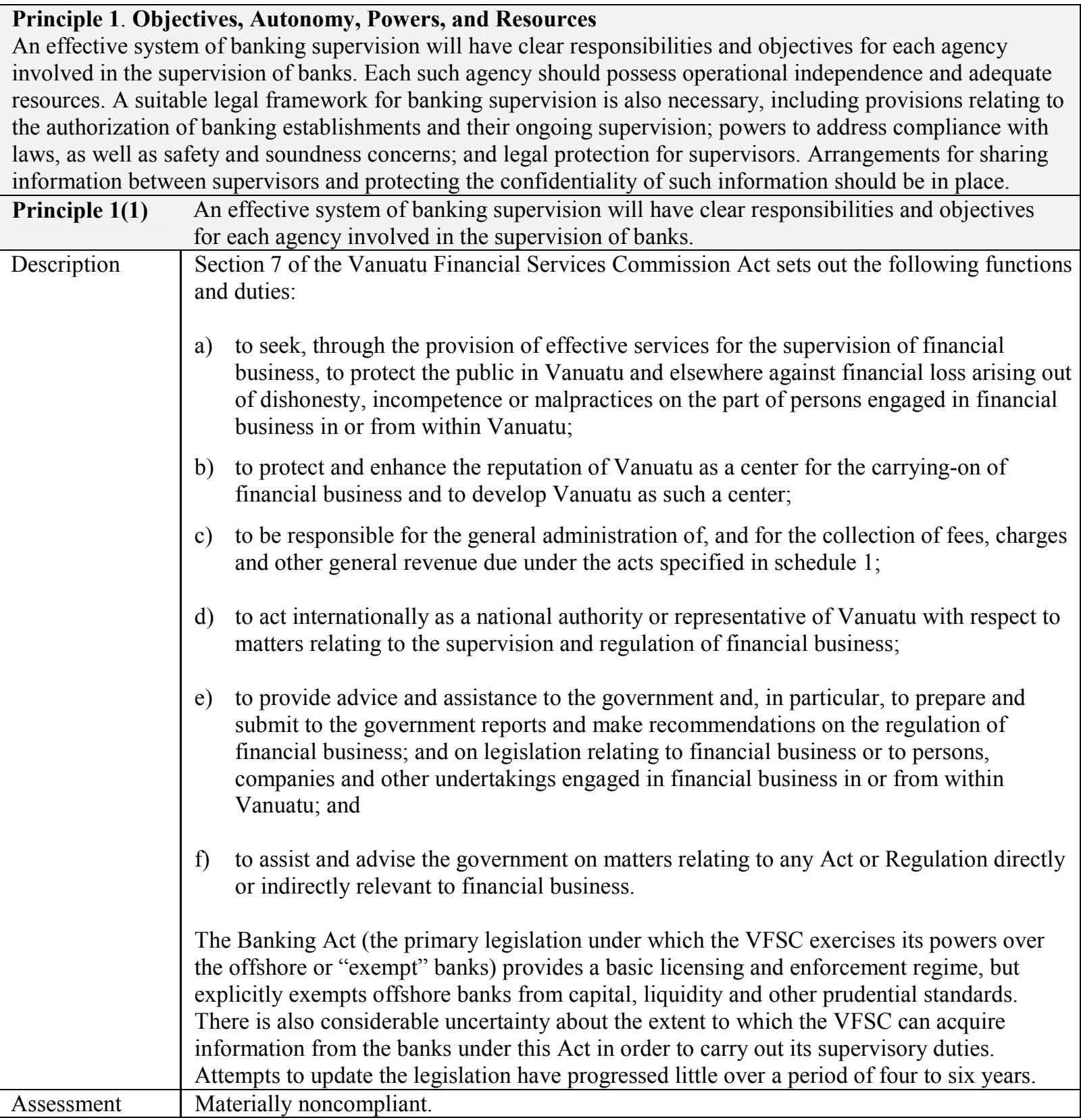




\begin{tabular}{|c|c|}
\hline Comments & $\begin{array}{l}\text { The Vanuatu Financial Services Commission Act clearly defines the role of the regulatory } \\
\text { authority and provides it with appropriate objectives. However, the Banking Act lacks any } \\
\text { real basis by which the VFSC can fulfill its objectives. This law was originally intended to } \\
\text { cover both domestic and offshore banks, but its objective with respect to the offshore sector is } \\
\text { apparent from the broad exemptions from any prudential requirements that it grants to } \\
\text { offshore institutions. The VFSC is only able to exercise any authority with respect to } \\
\text { prudential matters by the issue of directives on a general or case-by-case basis. The legal } \\
\text { authority for this approach is uncertain. } \\
\text { The deficiencies identified above and those in most following sections of the assessment can } \\
\text { really only be addressed by a major rewrite of the Banking Act to bring its provisions into } \\
\text { line with those relating to domestic banks in the Financial Institutions Act. This latter Act and } \\
\text { the guidelines and processes flowing from it, provide an appropriate model in most respects } \\
\text { for what is required for the offshore banking sector. }\end{array}$ \\
\hline Principle 1(2) & Each such agency should possess operational independence and adequate resources. \\
\hline Description & $\begin{array}{l}\text { Under the Banking Act the power to license, apply enforcement measures and to revoke } \\
\text { authorization are vested in the minister of finance. The VFSC acts in an advisory capacity to } \\
\text { the minister, but it has not been uncommon for the minister to act contrary to the advice of } \\
\text { the commission, particularly as regards the licensing of banks. } \\
\text { The VFSC Act provides for the board of the commission to comprise seven persons, } \\
\text { including the commissioner, who is the only full-time executive. Of the remaining six } \\
\text { positions, up to five may be filled by private sector representatives. The current chairman is } \\
\text { the chief executive of a local financial services group, of which some of the companies are } \\
\text { either directly subject to regulation by the VFSC or are acting as agents of regulated entities. } \\
\text { The legislation precludes the board from having access to information as to the affairs of } \\
\text { individual firms, but the board is responsible for the setting of policy, for the allocation of } \\
\text { resources, and for the appointment of senior personnel, including the commissioner. } \\
\text { The VFSC is funded by the company registration and license fees, and has the autonomy to } \\
\text { set its own budget, but in consultation with government. All surplus funds are passed } \\
\text { automatically to government, and the VFSC has no capacity to build up contingency reserves. } \\
\text { The banking supervision function within the commission is carried out by two persons, one } \\
\text { of whom has been in office for only a few months. There are no plans to increase this } \\
\text { resource. }\end{array}$ \\
\hline Assessment & Noncompliant. \\
\hline Comments & $\begin{array}{l}\text { All key regulatory decisions are vested in the minister, who may act entirely contrary to the } \\
\text { recommendations of the VFSC, and against whose decisions there is no appeal. Cases have } \\
\text { been encountered in the past when applicants have been able to access the minister directly } \\
\text { for decisions without going through the regulatory authority. } \\
\text { While private sector participation on the board of the regulatory authority is reasonable, the } \\
\text { extent of its involvement with the VFSC is excessive. A number of the board members are } \\
\text { active participants in the financial sector, some of whom control institutions directly } \\
\text { supervised by the VFSC. The chairman is the chief executive of one of the biggest players in } \\
\text { the local market. Only one of the board members has any executive capacity within the } \\
\text { VFSC, and the necessary provisions to exclude the board from any involvement in individual } \\
\text { cases (because of its composition) prevents the commissioner from having appropriate } \\
\text { support at a senior level within the agency. }\end{array}$ \\
\hline Principle 1(3) & $\begin{array}{l}\text { A suitable legal framework for banking supervision is also necessary, including provisions } \\
\text { relating to the authorization of banking establishments and their ongoing supervision. }\end{array}$ \\
\hline Description & $\begin{array}{l}\text { The Banking Act provides for the granting and revocation of banking licenses by the minister } \\
\text { of finance in consultation with the VFSC. This Act was originally introduced to cover the } \\
\text { regulation of both domestic and offshore banks, but now relates only to the offshore sector, } \\
\text { following the introduction in } 1999 \text { of the Financial Institutions Act for the domestic banks. }\end{array}$ \\
\hline
\end{tabular}




\begin{tabular}{|c|c|}
\hline & $\begin{array}{l}\text { Offshore banks are specifically exempted from the capital and other prudential norms } \\
\text { specified in the act. There is provision for the VFSC to issue directives, but the Act appears } \\
\text { to limit this power to specific circumstances, and does not explicitly permit it to be used to set } \\
\text { general prudential rules. A } 1995 \text { amendment to the Act gives the VFSC the power to conduct } \\
\text { examinations of the banks and to require the submission of information. However, many of } \\
\text { the banks believe that the disclosure of customer information, in particular, is prohibited } \\
\text { under Section } 381 \text { of the Companies Act, which provides for extensive secrecy in relation to } \\
\text { the affairs of "exempt" companies, which includes the offshore banks. }\end{array}$ \\
\hline Assessment & Noncompliant \\
\hline Comments & $\begin{array}{l}\text { The Banking Act is seriously deficient as the basis for a regulatory regime. The ability of the } \\
\text { VFSC to apply any prudential controls relies entirely on a liberal interpretation of its powers } \\
\text { to issue directives. Since the offshore banks are explicitly excluded from the financial } \\
\text { provisions of the Act, it must be questionable whether the VFSC can seek to apply a } \\
\text { substitute regime through the issue of directives. The lack of clarity about the VFSC's powers } \\
\text { to obtain information from the licensees is also a fundamental weakness, and one that is being } \\
\text { exploited by several licensees, which continue to refuse to submit any data to the VFSC. }\end{array}$ \\
\hline Principle 1(4) & $\begin{array}{l}\text { A suitable legal framework for banking supervision is also necessary, including powers to } \\
\text { address compliance with laws, as well as safety and soundness concerns. }\end{array}$ \\
\hline Description & $\begin{array}{l}\text { Section } 17 \text { of the Banking Act gives the VFSC certain powers if, on examination, it } \\
\text { concludes that a bank is carrying on its business in a manner detrimental to the interests of its } \\
\text { depositors or other creditors, is insolvent or is acting in contravention of the law. These } \\
\text { powers include the imposition of a requirement "to take such measures as the commission } \\
\text { may consider necessary," and to appoint someone to advise the institution on the proper } \\
\text { conduct of its business. The ultimate sanction is the revocation of the institution's license. }\end{array}$ \\
\hline Assessment & Materially noncompliant \\
\hline Comments & $\begin{array}{l}\text { In principle, the minister has the power to apply any control or sanction under the sweeping } \\
\text { powers of section } 17 \text {. However, the absence of a broader menu of specific, graduated options } \\
\text { creates uncertainty as to how the minister might use this power and could expose decisions to } \\
\text { a challenge on the grounds that they are unreasonable and do not have any basis in law. In } \\
\text { addition, the absence of any overt powers vested in the VFSC to exercise its powers to ensure } \\
\text { compliance seriously weakens its authority. }\end{array}$ \\
\hline Principle 1(5) & $\begin{array}{l}\text { A suitable legal framework for banking supervision is also necessary, including legal } \\
\text { protection for supervisors. }\end{array}$ \\
\hline Description & $\begin{array}{l}\text { Section } 21 \text { of the VFSC Act provides protection against either suit or prosecution, where the } \\
\text { VFSC or its staff have acted in good faith in exercising their powers under either the VFSC } \\
\text { or any other Acts. Expenses incurred by the commission in defending itself against action } \\
\text { must be borne by the commission, unless recovered through the courts. The costs of } \\
\text { individual employees are to be borne by the commission (unless recovered through the } \\
\text { courts), provided that the employee is shown to have acted in good faith. }\end{array}$ \\
\hline Assessment & Compliant \\
\hline Comments & Desirably, this provision should be carried forward. \\
\hline Principle 1(6) & $\begin{array}{l}\text { Arrangements for sharing information between supervisors and protecting the confidentiality } \\
\text { of such information should be in place. }\end{array}$ \\
\hline Description & $\begin{array}{l}\text { Both the VFSC Act and the Banking Act are silent on the issue of information sharing with } \\
\text { either domestic or foreign regulators. However, section } 381 \text { of the Companies Act precludes } \\
\text { the disclosure by the VFSC, in its capacity as registrar, of any information in relation to an } \\
\text { exempt company (including an offshore bank). Exemptions are provided only where required } \\
\text { for the registrar to perform his functions under the Companies Act, where compelled under } \\
\text { another law, or where required by a court. }\end{array}$ \\
\hline Assessment & Noncompliant \\
\hline Comments & $\begin{array}{l}\text { The absence of any legal "gateways" within the regulatory laws, under which the VFSC can } \\
\text { exchange information and otherwise cooperate with other domestic and foreign regulators, } \\
\text { conflicts with this principle. }\end{array}$ \\
\hline
\end{tabular}




\begin{tabular}{|c|c|}
\hline \multicolumn{2}{|c|}{$\begin{array}{l}\text { Principle 2. Permissible Activities } \\
\text { The permissible activities of institutions that are licensed and subject to supervision as banks must be clearly } \\
\text { defined, and the use of the word "bank" in names should be controlled as far as possible. }\end{array}$} \\
\hline \multicolumn{2}{|r|}{$\begin{array}{l}\text { The Banking Act defines a financial institution as an institution carrying on banking business, } \\
\text { which is defined as the business of accepting deposits which may be withdrawn or repaid on } \\
\text { demand, and which are employed at the risk of the institution. A bank is further defined to mean } \\
\text { a financial institution that accepts deposits withdrawable by check. Under section } 2 \text { of the Act, } \\
\text { banking business may only be carried on by a licensed financial institution. An offence against } \\
\text { this provision involves only a fine of less than } \$ 400 \text { per day, and no custodial sentence. } \\
\text { Section } 10 \text { reserves the use of the word "bank" and its derivatives for licensed banks, but grants } \\
\text { the minister the power, acting on the advice of the VFSC to make exceptions. }\end{array}$} \\
\hline Assessment & Large \\
\hline $\mathrm{omr}$ & $\begin{array}{l}\text { The sanctions for carrying on a banking business without a license are unlikely to pose a serious } \\
\text { deterrent in many cases. }\end{array}$ \\
\hline \multicolumn{2}{|c|}{$\begin{array}{l}\text { Principle 3. Licensing Criteria } \\
\text { The licensing authority must have the right to set criteria and reject applications for establishments that do not } \\
\text { meet the standards set. The licensing process, at a minimum, should consist of an assessment of the banking } \\
\text { organization's ownership structure, directors and senior management; its operating plan and internal controls, } \\
\text { and its projected financial condition, including its capital base; where the proposed owner or parent organization } \\
\text { is a foreign bank, the prior consent of its home country supervisor should be obtained. }\end{array}$} \\
\hline Description & 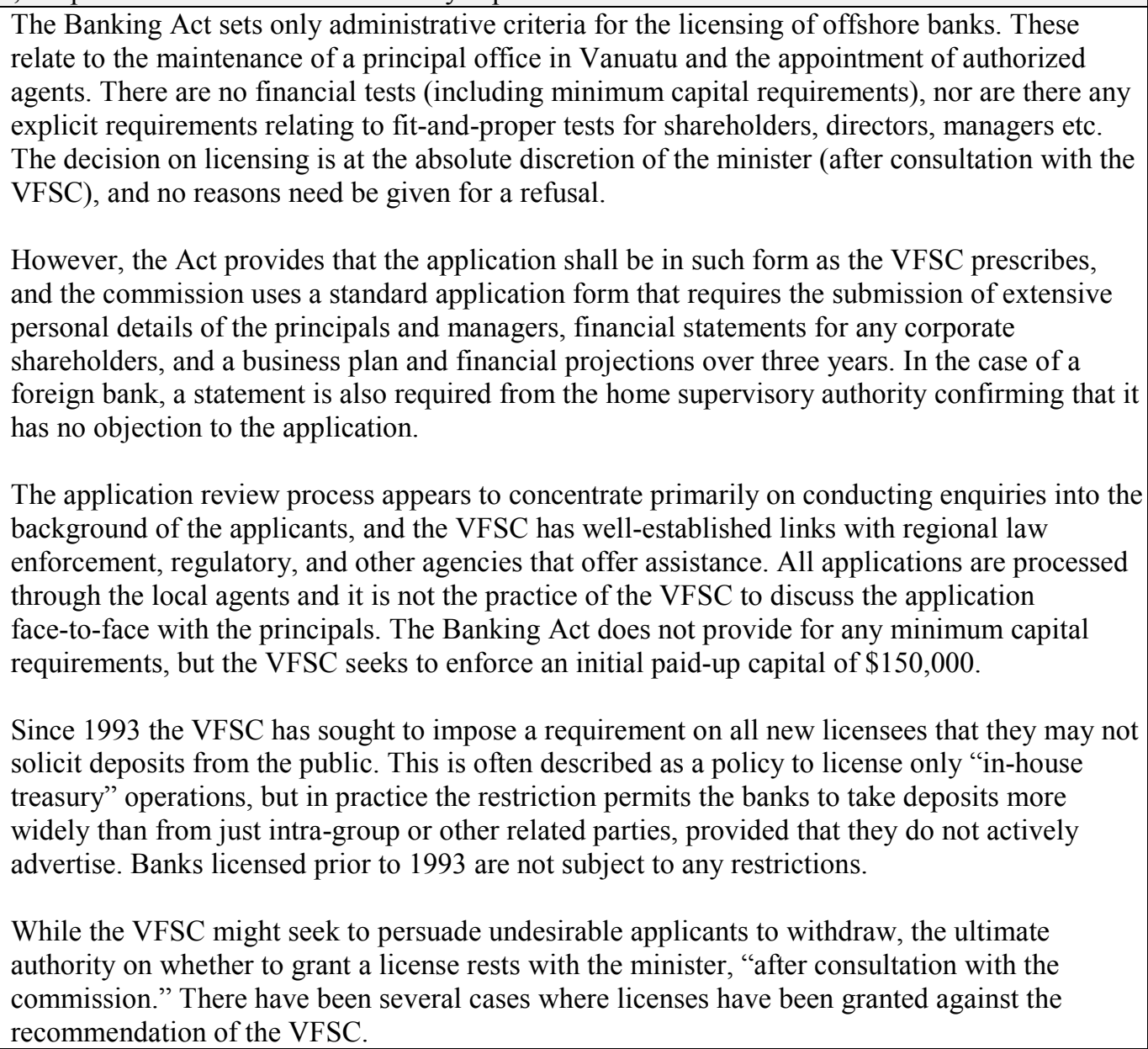 \\
\hline Assessment & Materially noncompliant \\
\hline Comments & \\
\hline
\end{tabular}




\begin{tabular}{|c|c|}
\hline & $\begin{array}{l}\text { practice of the VFSC to deal with applications on a purely paper basis, and not to require direct } \\
\text { face-to-face contact with the applicants, denies it an important tool in its assessment of } \\
\text { compliance with the criteria that it seeks to set administratively }\end{array}$ \\
\hline \multicolumn{2}{|c|}{$\begin{array}{l}\text { Principle 4. Ownership } \\
\text { Banking supervisors must have the authority to review and reject any proposals to transfer significant } \\
\text { ownership or controlling interests in existing banks to other parties. }\end{array}$} \\
\hline Description & $\begin{array}{l}\text { There are no provisions under the Banking Act that either require notification of a change of } \\
\text { ownership or control, or which give the VFSC the authority to approve or object to any changes } \\
\text { when they are identified. The VFSC seeks to require notification of any changes through } \\
\text { administrative procedures. The Companies Act requires an annual filing by exempt (i.e., } \\
\text { offshore) banks, which includes details of shareholders and directors. This is the primary } \\
\text { process through which the VFSC can monitor any changes in ownership or control. }\end{array}$ \\
\hline Assessment & Noncompliant \\
\hline Comments & $\begin{array}{l}\text { The absence of any direct, overt controls over subsequent changes of beneficial ownership } \\
\text { seriously undermines the VFSC's attempts to impose fit-and-proper tests at the time of } \\
\text { licensing. The Companies Act filing requirements are after the event, and do not involve any } \\
\text { qualitative criteria. }\end{array}$ \\
\hline \multicolumn{2}{|c|}{$\begin{array}{l}\text { Principle 5. Investment Criteria } \\
\text { Banking supervisors must have the authority to establish criteria for reviewing major acquisitions or } \\
\text { investments by a bank and ensuring that corporate affiliations or structures do not expose the bank to undue } \\
\text { risks or hinder effective supervision. }\end{array}$} \\
\hline Description & $\begin{array}{l}\text { There are no legal provisions that permit the VFSC to control or review the extent to which } \\
\text { institutions may invest in subsidiaries or affiliates. }\end{array}$ \\
\hline Assessment & Noncompliant \\
\hline Comments & $\begin{array}{l}\text { The absence of any controls over, or notification requirements for investment in subsidiaries or } \\
\text { affiliates not only hinders the VFSC's ability to assess overall risk, but also prevents it from } \\
\text { determining whether or not it has a responsibility to undertake supervision on a consolidated } \\
\text { basis }\end{array}$ \\
\hline \multicolumn{2}{|c|}{$\begin{array}{l}\text { Principle 6. Capital Adequacy } \\
\text { Banking supervisors must set minimum capital adequacy requirements for banks that reflect the risks that the } \\
\text { bank undertakes, and must define the components of capital, bearing in mind its ability to absorb losses. For } \\
\text { internationally active banks, these requirements must not be less than those established in the Basel Capital } \\
\text { Accord. }\end{array}$} \\
\hline Description & $\begin{array}{l}\text { The VFSC does not apply any capital adequacy measures, beyond an administrative requirement } \\
\text { that the initial paid-up capital of a licensee should be } \$ 150,000 \text {. This requirement has no legal } \\
\text { backing. }\end{array}$ \\
\hline Assessment & Noncompliant \\
\hline Comments & $\begin{array}{l}\text { The absence of any minimum statutory capital requirements for entry to the market needs to be } \\
\text { remedied. The across-the-board figure of } \$ 150,000 \text { used on an administrative basis by the VFSC } \\
\text { is extremely low, and takes no account of the risks that the institution will be undertaking. While } \\
\text { some attempts are being made by the VFSC to monitor capital on an ongoing basis, the data it } \\
\text { receives does not permit any meaningful assessment, and it lacks the authority to require } \\
\text { improvements if it were to consider this to be necessary. }\end{array}$ \\
\hline \multicolumn{2}{|c|}{$\begin{array}{l}\text { Principle 7. Credit Policies } \\
\text { An essential part of any supervisory system is the independent evaluation of a bank's policies, practices, and } \\
\text { procedures related to the granting of loans and making of investments, and the ongoing management of the loan } \\
\text { and investment portfolios. }\end{array}$} \\
\hline Description & $\begin{array}{l}\text { The VFSC has no procedure for reviewing or evaluating banks' credit policies, practices, and } \\
\text { procedures. }\end{array}$ \\
\hline Assessment & Noncompliant \\
\hline Comments & $\begin{array}{l}\text { The nature of the offshore banking sector, where only three institutions have any form of } \\
\text { physical presence in Vanuatu, makes it impracticable for the VFSC itself to verify the standard } \\
\text { of the practices within the banks. Furthermore, no attempt is made to use the external auditors to } \\
\text { review and report on these issues. }\end{array}$ \\
\hline
\end{tabular}




\begin{tabular}{|c|c|}
\hline & $\begin{array}{l}\text { If supervision of the offshore banks is to be carried out effectively at reasonable cost, it will also } \\
\text { be necessary to require that all offshore licensed banks either have an operational presence in } \\
\text { Vanuatu (management and records) or be subject to international standard supervision in the } \\
\text { jurisdiction in which their management and records are based. Many existing licensees are "shell } \\
\text { banks" and there is no practical way they can be adequately supervised while that situation } \\
\text { prevails. }\end{array}$ \\
\hline \multicolumn{2}{|c|}{$\begin{array}{l}\text { Principle 8. Loan Evaluation and Loan-Loss Provisioning } \\
\text { Banking supervisors must be satisfied that banks establish and adhere to adequate policies, practices, and } \\
\text { procedures for evaluating the quality of assets and the adequacy of loan-loss provisions and reserves. }\end{array}$} \\
\hline Description & $\begin{array}{l}\text { The VFSC has no policies or procedures in relation to asset quality, classification, and } \\
\text { provisioning. }\end{array}$ \\
\hline Assessment & Noncompliant \\
\hline Comments & $\begin{array}{l}\text { The VFSC has not implemented any guidelines on loan loss provisions, and has no basis on } \\
\text { which to assess the adequacy of any provisions that might be reported by the banks. The nature } \\
\text { of the offshore banking sector, where only three institutions have any form of physical presence } \\
\text { in Vanuatu, makes it impracticable for the VFSC itself to verify the nature and standard of the } \\
\text { practices within the banks. Attempts were made to use the external auditors to review and report } \\
\text { on these issues, beyond what might be addressed in the banks' annual audit, but the banks were } \\
\text { unwilling to meet the costs of work that was not specifically required by law. }\end{array}$ \\
\hline \multicolumn{2}{|c|}{$\begin{array}{l}\text { Principle 9. Large Exposure Limits } \\
\text { Banking supervisors must be satisfied that banks have management information systems that enable } \\
\text { management to identify concentrations within the portfolio, and supervisors must set prudential limits to restrict } \\
\text { bank exposures to single borrowers or groups of related borrowers. }\end{array}$} \\
\hline Description & $\begin{array}{l}\text { The Banking Act exempts the offshore banks from controls on credit exposures and the VFSC } \\
\text { has no separate legal authority to establish any limits on risk concentration; nor has it } \\
\text { established any policy on this issue. It receives quarterly data on large credit exposures, but this } \\
\text { is for information purposes only. }\end{array}$ \\
\hline Assessment & Noncompliant \\
\hline Com & $\begin{array}{l}\text { An argument has been made that, because the offshore banks have restrictions limiting their } \\
\text { activities to "in-house" operations, there is no need to apply controls on large exposures. In } \\
\text { practice; however, this restriction does not limit the range of the banks' activities to the extent } \\
\text { often claimed, and it is apparent that their customer base extends beyond related parties. } \\
\text { Therefore, the ability to apply a large exposures policy remains an essential feature that is } \\
\text { lacking in Vanuatu. } \\
\text { It would be desirable in this area, and in that covered by Principle } 10 \text { for the legislation, to be } \\
\text { less specific in terms of limits and leave more discretion with the supervisor. }\end{array}$ \\
\hline \multicolumn{2}{|c|}{$\begin{array}{l}\text { Principle 10. Connected Lending } \\
\text { In order to prevent abuses arising from connected lending, banking supervisors must have in place requirements } \\
\text { that banks lend to related companies and individuals on an arm's-length basis, that such extensions of credit are } \\
\text { effectively monitored, and that other appropriate steps are taken to control or mitigate the risks. }\end{array}$} \\
\hline Description & $\begin{array}{l}\text { The Banking Act exempts offshore banks from controls on credit exposures, and the VFSC does } \\
\text { not apply any policy in this area. It receives statistical data to capture the aggregate of related } \\
\text { party exposure. }\end{array}$ \\
\hline Assessment & Noncompliant \\
\hline Comments & See comments under 7 and 9 above. \\
\hline \multicolumn{2}{|c|}{$\begin{array}{l}\text { Principle 11. Country Risk } \\
\text { Banking supervisors must be satisfied that banks have adequate policies and procedures for identifying, } \\
\text { monitoring, and controlling country risk and transfer risk in their international lending and investment activities, } \\
\text { and for maintaining appropriate reserves against such risks. }\end{array}$} \\
\hline Description & The VFSC has no policy on country risk, and receives no relevant data. \\
\hline Assessment & Noncompliant \\
\hline Comments & $\begin{array}{l}\text { The extent to which this is a material factor is unclear, due to the absence of any data on the } \\
\text { cross-border activities of the banks. }\end{array}$ \\
\hline
\end{tabular}




\begin{tabular}{|c|c|}
\hline \multicolumn{2}{|c|}{$\begin{array}{l}\text { Banking supervisors must be satisfied that banks have in place systems that accurately measure, monitor, and } \\
\text { adequately control market risks; supervisors should have powers to impose specific limits and/or a specific } \\
\text { capital charge on market risk exposure, if warranted. }\end{array}$} \\
\hline Description & The VFSC does not address market risk in its supervisory procedures. \\
\hline Assessment & Noncompliant. \\
\hline Comments & $\begin{array}{l}\text { The extent to which this is a material factor is unclear due to the absence of data on the foreign } \\
\text { exchange and other market risk exposures. The inability of the VFSC to conduct any on-site } \\
\text { reviews of the majority of the bank precludes it from assessing the level of risk and what } \\
\text { controls might be in place }\end{array}$ \\
\hline \multicolumn{2}{|c|}{ Principle 13. Other Risks } \\
\hline \multicolumn{2}{|c|}{$\begin{array}{l}\text { Banking supervisors must be satisfied that banks have in place a comprehensive risk management process } \\
\text { (including appropriate board and senior management oversight) to identify, measure, monitor, and control all } \\
\text { other material risks and, where appropriate, to hold capital against these risks. }\end{array}$} \\
\hline Description & $\begin{array}{l}\text { The VFSC receives quarterly data on liquidity, but has no policies or procedures in place to } \\
\text { ensure appropriate standards and processes of liquidity management. Other forms of risk } \\
\text { management are not monitored or addressed. }\end{array}$ \\
\hline Asses & Nor \\
\hline Com & \\
\hline \multicolumn{2}{|c|}{$\begin{array}{l}\text { Principle 14. Internal Control and Audit } \\
\text { Banking supervisors must determine that banks have in place internal controls that are adequate for the nature } \\
\text { and scale of their business. These should include clear arrangements for delegating authority and responsibility; } \\
\text { separation of the functions that involve committing the bank, paying away its funds, and accounting for its } \\
\text { assets and liabilities; reconciliation of these processes; safeguarding its assets; and appropriate independent } \\
\text { internal or external audit and compliance functions to test adherence to these controls, as well as applicable laws } \\
\text { and regulations. }\end{array}$} \\
\hline Description & $\begin{array}{l}\text { Information on the proposed internal systems and controls and business plan is obtained by the } \\
\text { VFSC at the licensing stage. Thereafter, the VFSC has no procedure by which it can monitor the } \\
\text { adequacy of, and compliance with the controls. Although the VFSC seeks to require banks to } \\
\text { provide notification of any changes in senior management, there is no explicit legal authority for } \\
\text { this. Equally, there are no specific powers to bring about the removal of poor management, but } \\
\text { the minister of finance has the authority to require the appointment of an adviser to assist a } \\
\text { financial institution in the event that serious deficiencies in the management are identified. }\end{array}$ \\
\hline Assessment & Noncompliant \\
\hline Comments & $\begin{array}{l}\text { The inability to conduct any form of meaningful on-site examination puts an assessment of these } \\
\text { issues outside the scope of the VFSC. In addition, since there is an almost total lack of direct } \\
\text { contact with the management of the licensed institutions, it is extremely difficult for the VFSC } \\
\text { to gain an impression of the control environment and of the quality of management. There is no } \\
\text { policy on the need for an internal audit function, and the VFSC does not have access to any } \\
\text { reports that might be produced where such a function does exist. Due to the costs, no use is } \\
\text { made of the external auditors to report on the control environment during the course of their } \\
\text { work, and the auditors are prevented by statute from discussing the clients' affairs directly with } \\
\text { the VFSC. }\end{array}$ \\
\hline \multicolumn{2}{|c|}{$\begin{array}{l}\text { Principle 15. Money Laundering } \\
\text { Banking supervisors must determine that banks have adequate policies, practices, and procedures in place, } \\
\text { including strict "know-your-customer" rules, which promote high ethical and professional standards in the } \\
\text { financial sector and prevent the bank being used, intentionally or unintentionally, by criminal elements. }\end{array}$} \\
\hline Description & $\begin{array}{l}\text { Vanuatu has enacted a range of laws in relation to money laundering (see separate section and } \\
\text { annex of the report). These laws apply equally in all respects to offshore banks, and the VFSC } \\
\text { has issued a series of Practice Notes to the sector reminding them of their legal obligations. } \\
\text { However, the VFSC has no procedures in place to verify that the banks have adequate systems } \\
\text { to combat money laundering and that they are complying with their legal obligations. A } \\
\text { requirement by the FIU that all banks should submit copies of their anti-money laundering } \\
\text { policy manuals has been rejected by five offshore banks on the grounds that such controls are } \\
\text { irrelevant to their business. }\end{array}$ \\
\hline
\end{tabular}




\begin{tabular}{|c|c|}
\hline Assessment & Materially noncompliant \\
\hline Comments & See comments in Part VII of this report. \\
\hline \multicolumn{2}{|c|}{$\begin{array}{l}\text { Principle 16. On-site and Off-site Supervision } \\
\text { An effective banking supervisory system should consist }\end{array}$} \\
\hline Description & $\begin{array}{l}\text { The VFSC has authority under sections } 15 \text { and } 16 \text { of the Banking Act to carry out examinations } \\
\text { of offshore banks and to require the disclosure of all books, records and other information in that } \\
\text { process. However, only } 3 \text { of the } 34 \text { offshore banks have any form of physical presence in } \\
\text { Vanuatu beyond the statutory appointment of a local agent for the purposes of serving legal } \\
\text { notice. There is no obligation for these agents to maintain other than basic statutory records in } \\
\text { the jurisdiction. } \\
\text { The VFSC has started a program of conducting "on-site" meetings with the agents on the basis } \\
\text { of a checklist of questions submitted to the agents one month in advance. This checklist relates } \\
\text { exclusively to financial data that the agents are expected to acquire from their clients. The } \\
\text { bank's management is invited to attend the meeting with the agent, but, almost without } \\
\text { exception, such invitations have been declined. In most cases the VFSC has never met a member } \\
\text { of the management of the licensed offshore banks. Twenty-two "on-site" reviews have been } \\
\text { undertaken in the past two years, and the VFSC has set a target of conducting one per month. } \\
\text { Priority is given to those cases where the VFSC has reason for concern, mostly derived from } \\
\text { external information sources. The VFSC does not have the resources even to consider } \\
\text { conducting on-site visits to the actual locations in which the banks operate. } \\
\text { Off-site supervision is based on the submission of quarterly statistical returns, which capture } \\
\text { basic balance sheet information (including some breakdown of risk concentration) and a } \\
\text { maturity analysis. In addition, all banks are required under the Companies Act to submit audited } \\
\text { financial statements annually. The accounts are almost invariably filed well after the statutory } \\
\text { period. The requirement for the submission of quarterly returns has no legal basis, unless } \\
\text { incorporated as a condition of the original license, and five banks of long standing continue to } \\
\text { refuse to submit the returns. The VFSC has not attempted any enforcement action to ensure } \\
\text { compliance. The returns are used almost entirely for statistical purposes, but some basic analysis } \\
\text { of risk is undertaken. }\end{array}$ \\
\hline Assessment & Materially noncompliant \\
\hline Comments & $\begin{array}{l}\text { There is no meaningful form of on-site examination in place, and the nature of the offshore } \\
\text { sector makes it impracticable for the VFSC to implement an effective system. The alternative } \\
\text { option of using the external auditors to perform some functions on behalf of the supervisors is } \\
\text { not employed (due mainly to the costs involved) and is effectively precluded by the secrecy } \\
\text { provisions within the legislation. } \\
\text { The attempt to introduce a reporting system to provide the basis of an off-site surveillance } \\
\text { process was a positive development, but is materially deficient (see Principle 18). }\end{array}$ \\
\hline \multicolumn{2}{|c|}{$\begin{array}{l}\text { Principle 17. Bank Management Contact } \\
\text { Banking supervisors must have regular contact with bank management and a thorough understanding of the } \\
\text { institution's operations. }\end{array}$} \\
\hline Description & $\begin{array}{l}\text { Only } 3 \text { of the } 34 \text { offshore banks have a form of physical presence involving real "mind and } \\
\text { management" in Vanuatu. In virtually every other case the VFSC has never had a meeting with } \\
\text { the management of the institutions. There have been no attempts to meet management when the } \\
\text { regulators are overseas on official travel. }\end{array}$ \\
\hline Assessment & Noncompliant \\
\hline Comments & $\begin{array}{l}\text { The VFSC makes occasional requests for meetings with the management of the offshore banks, } \\
\text { but these are rarely agreed to by the banks, largely because of the inconvenience of having to } \\
\text { travel to Vanuatu, but also because they do not believe that the VFSC has the authority to } \\
\text { enquire into their affairs. As a result, the VFSC can only rely on the local agents acting as } \\
\text { intermediaries in passing requests for information. This process does not permit VFSC to obtain } \\
\text { a proper understanding of the operations of the banks. }\end{array}$ \\
\hline
\end{tabular}




\begin{tabular}{|c|c|}
\hline \multicolumn{2}{|c|}{$\begin{array}{l}\text { Principle 18. Off-site Supervision } \\
\text { Banking supervisors must have a means of collecting, reviewing, and analyzing prudential reports and statistical } \\
\text { returns from banks on a solo and consolidated basis. }\end{array}$} \\
\hline Description & $\begin{array}{l}\text { There is no specific legal authority for requiring the banks to submit data to the VFSC apart } \\
\text { from the audited annual accounts. In recent years there has been an attempt to introduce a } \\
\text { quarterly reporting system, but five banks continue to refuse to comply with the request. The } \\
\text { VFSC does not consider that it has the power to force the issue. The reports obtained are in } \\
\text { standard form and contain a limited amount of balance sheet and supplementary data. The data } \\
\text { are entered into the VFSC's computer system in a spreadsheet format that mirrors the reporting } \\
\text { form. Only a limited amount of analysis is undertaken. } \\
\text { Under section } 15 \text { and } 16 \text { of the Banking Act the VFSC is given the power to require any } \\
\text { information from the banks. However, the banks claim that the secrecy provisions of the } \\
\text { Companies Act have precedence, and that these preclude the submission of information relating } \\
\text { to the identity of individual customers. The VFSC has not sought to challenge this. }\end{array}$ \\
\hline Assessment & Materially noncompliant \\
\hline Cor & $\begin{array}{l}\text { The introduction of a quarterly reporting system was a positive step. However, not all the banks } \\
\text { are complying with the request for data, and the VFSC does not appear to have any authority (or } \\
\text { will) to enforce compliance. The data captured in the returns is far from comprehensive and does } \\
\text { not permit a proper assessment of capital adequacy or other prudential norms. Moreover, there is } \\
\text { no mechanism for verifying that the data submitted is accurate, and the VFSC has experience of } \\
\text { cases where the quarterly data varies significantly from the corresponding data in the audited } \\
\text { financial statements. } \\
\text { The apparent conflicting interpretations of the law with respect to the VFSC's powers to obtain } \\
\text { information from the banks present a serious obstacle to development of the off-site process. } \\
\text { The amendment to the Banking Act post-dates the Companies Act provisions and would } \\
\text { normally be considered to have overriding force. However, as long as this remains untested in } \\
\text { the courts or is not put beyond all doubt by further amendments to the law, the VFSC's } \\
\text { unwillingness to press for disclosure undermines its authority. }\end{array}$ \\
\hline \multicolumn{2}{|c|}{$\begin{array}{l}\text { Principle 19. Validation of Supervisory Information } \\
\text { Banking supervisors must have a means of independent validation of supervisory information either through on- } \\
\text { site examinations or use of external auditors. }\end{array}$} \\
\hline Description & \\
\hline & \\
\hline Comr & $\begin{array}{l}\text { The VFSC is not in a position to undertake a relevant on-site procedure itself, and there is no } \\
\text { obligation imposed on the auditors to check the accuracy of the quarterly returns. }\end{array}$ \\
\hline \multicolumn{2}{|c|}{$\begin{array}{l}\text { Principle 20. Consolidated Supervision } \\
\text { An essential element of banking supervision is the ability of the supervisors to supervise the banking group on a } \\
\text { consolidated basis. }\end{array}$} \\
\hline Description & $\begin{array}{l}\text { Not applicable, to the extent that the VFSC is not aware that any of its licensees has established } \\
\text { any branches or subsidiaries. }\end{array}$ \\
\hline Asses & \\
\hline Comments & \\
\hline \multicolumn{2}{|c|}{$\begin{array}{l}\text { Principle 21. Accounting Standards } \\
\text { Banking supervisors must be satisfied that each bank maintains adequate records drawn up in accordance with } \\
\text { consistent accounting policies and practices; which enable the supervisor to obtain a true and fair view of the } \\
\text { financial condition of the bank and the profitability of its business; and that the bank publishes on a regular } \\
\text { basis financial statements that fairly reflect its condition. }\end{array}$} \\
\hline Description & $\begin{array}{l}\text { The VFSC has no specific authority to specify the accounting standards to be used by financial } \\
\text { institutions, nor does it have the ability to verify, through on-site examination, the standards } \\
\text { being applied. Sole reliance is placed on the external audit, for which there is a general } \\
\text { expectation that accepted international accounting standards will be used. There is no obligation } \\
\text { imposed on the banks to publish their audited accounts or any other information, and it is an } \\
\text { offence for any person to disclose the audited accounts filed with the VFSC. }\end{array}$ \\
\hline
\end{tabular}




\begin{tabular}{|c|c|}
\hline & $\begin{array}{l}\text { The appointment of auditors is subject to the approval of the minister, but there is no specific } \\
\text { power for the minister to revoke this approval. However, this may be done under the general } \\
\text { powers to require an institution to take such remedial actions as may be considered necessary. } \\
\text { There is no requirement that the auditors for Vanuatu-incorporated banks must be located within } \\
\text { the jurisdiction. The auditors are bound by the secrecy provisions of the Companies Act and } \\
\text { may not disclose information directly to the VFSC without the approval of the client bank. } \\
\text { There are no "whistle-blowing" duties imposed on the auditors, and there is no practice whereby } \\
\text { the auditors are used to carry out specific tasks or investigations at the instigation of the } \\
\text { supervisory authority. }\end{array}$ \\
\hline Assessment & Materially noncompliant \\
\hline Comments & $\begin{array}{l}\text { The VFSC relies entirely upon the external audit process, but has no mechanism either for } \\
\text { determining and verifying the standards to which the audits are completed, or for } \\
\text { communicating with the auditors on issues relevant to the audit. Indeed, the auditors are } \\
\text { prevented by the secrecy provisions from communicating directly with the regulators. In } \\
\text { addition, the institutions are based entirely outside the jurisdiction and the audits are usually } \\
\text { undertaken by foreign auditors applying the standards applicable in their home country. This } \\
\text { prevents the VFSC from having a clear understanding of the basis of the accounting standards, } \\
\text { or of the consistency of approach across the sector. } \\
\text { There is no requirement for offshore banks to publish any form of financial data on their } \\
\text { activities, even where they may be taking deposits from the public. }\end{array}$ \\
\hline \multicolumn{2}{|c|}{$\begin{array}{l}\text { Principle 22. Remedial Measures } \\
\text { Banking supervisors must have at their disposal adequate supervisory measures to bring about timely corrective } \\
\text { action when banks fail to meet prudential requirements (such as minimum capital adequacy ratios), when there } \\
\text { are regulatory violations, or where depositors are threatened in any other way. In extreme circumstances, this } \\
\text { should include the ability to revoke the banking license or recommend its revocation. }\end{array}$} \\
\hline Description & $\begin{array}{l}\text { Section } 17 \text { of the Banking Act empowers the minister to require a financial institution to take } \\
\text { such measures as he considers appropriate to remedy matters considered by the VFSC to pose a } \\
\text { threat to the interests of depositors or to the solvency of the institution. He may also appoint a } \\
\text { person to advise the institution on the proper conduct of its affairs. The ultimate sanction is } \\
\text { revocation of the license. There are no powers to impose administrative fines except for late } \\
\text { payment of the annual fees. Section 4(4)(b) of the Act provides for the revocation of a license } \\
\text { for failure to comply with a directive issued by the VFSC, but, with one limited exception, the } \\
\text { Act appears not to identify circumstances under which the VFSC may issue a directive. } \\
\text { Notwithstanding this, the VFSC has adopted the practice of using this procedure in an attempt to } \\
\text { enforce its will where it lacks clear legal authority. } \\
\text { In recent years, a substantial number of bank licenses have been revoked, reducing the number } \\
\text { from a peak of about } 110 \text { to the current level of } 34 \text {. Many of these revocations have been for } \\
\text { nonpayment of fees or on the grounds that the institution has ceased to conduct banking } \\
\text { business. }\end{array}$ \\
\hline Assessment & Materially noncompliant \\
\hline Comments & $\begin{array}{l}\text { In principle, the VFSC, acting through the minister, would appear to have a wide range of } \\
\text { enforcement powers, given the broad discretion permitted under section } 17 \text { of the Banking Act. } \\
\text { However, these powers are too general and do not explicitly provide for a range of graduated } \\
\text { options that are transparent and subject to appropriate checks and balances. In addition, all the } \\
\text { powers are vested directly in the minister and the VFSC itself has no apparent authority to take } \\
\text { action of its own accord. The practice of issuing directives to overcome this weakness has an } \\
\text { uncertain basis in law. The most common form of enforcement measure adopted under the } \\
\text { Banking Act appears to be revocation of the license. There are no measures that allow the } \\
\text { supervisors to take control of the institution to ensure that the assets are protected and that there } \\
\text { is an orderly winding-up and distribution. }\end{array}$ \\
\hline
\end{tabular}




\begin{tabular}{|c|c|}
\hline \multicolumn{2}{|c|}{$\begin{array}{l}\text { Principle 23. Globally Consolidated Supervision } \\
\text { Banking supervisors must practice globally consolidated supervision over their internationally active banking } \\
\text { organizations, adequately monitoring and applying appropriate prudential norms to all aspects of the business } \\
\text { conducted by these banking organizations worldwide, primarily at their foreign branches, joint ventures, and } \\
\text { subsidiaries. }\end{array}$} \\
\hline Description & $\begin{array}{l}\text { Not applicable, to the extent that the VFSC is not aware that any of the banks have foreign } \\
\text { branches or subsidiaries. }\end{array}$ \\
\hline Assessment & Not applicable. \\
\hline \multicolumn{2}{|l|}{ Comments } \\
\hline Principle 24. & $\begin{array}{l}\text { Host Country Supervision } \\
\text { A key component of consolidated supervision is establishing contact and information exchange } \\
\text { with the various other supervisors involved, primarily host country supervisory authorities. }\end{array}$ \\
\hline Description & Not applicable \\
\hline Assessment & Not applicable \\
\hline \multicolumn{2}{|l|}{ Comments } \\
\hline \multicolumn{2}{|c|}{$\begin{array}{l}\text { Principle 25. Supervision over Foreign Banks' Establishments } \\
\text { Banking supervisors must require the local operations of foreign banks to be conducted with the same high } \\
\text { standards as are required of domestic institutions and must have powers to share information needed by the } \\
\text { home country supervisors of those banks for the purpose of carrying out consolidated supervision. }\end{array}$} \\
\hline Description & $\begin{array}{l}\text { The VFSC is host supervisor to five subsidiaries of foreign banks. As part of the authorization } \\
\text { process, a statement is required confirming that the home supervisor has no objection to the } \\
\text { establishment of the subsidiary. However, the VFSC is prohibited by the secrecy provisions of } \\
\text { the Companies Act from revealing any information in relation to the affairs of an offshore bank. } \\
\text { There are no "gateways" within either the VFSC Act or the Banking Act that override these } \\
\text { secrecy provisions. That said, the VFSC has sought on many occasions to assist overseas } \\
\text { authorities to the greatest extent possible. The secrecy laws would preclude the possibility of } \\
\text { on-site examination by a home supervisor, but this is not a practical consideration given the } \\
\text { absence of any physical presence of the banks in Vanuatu. }\end{array}$ \\
\hline Assessment & Noncompliant \\
\hline Comments & $\begin{array}{l}\text { The absence of any "gateways" for regulator-to-regulator exchanges of information seriously } \\
\text { hinders effective supervision of cross-border activities. Any attempt by the staff of the VFSC to } \\
\text { share information potentially exposes them to criminal liability under the Companies Act. } \\
\text { Although the VFSC is not known to be the home supervisor for any bank with overseas } \\
\text { operations, virtually all the licensed banks have their operational base overseas. Therefore, it is } \\
\text { essential that the VFSC should be able and willing to communicate on a confidential basis with } \\
\text { fellow regulators. }\end{array}$ \\
\hline
\end{tabular}


Table 4. Summary Compliance with the Basel Core Principles-Offshore Banks

\begin{tabular}{|c|c|c|c|c|c|}
\hline Core Principle & $\mathrm{C}^{1 /}$ & $\mathrm{LC}^{2 /}$ & $\mathrm{MNC}^{-3 /}$ & $\mathrm{NC}^{4 /}$ & $\mathrm{NA}^{\frac{5 /}{1}}$ \\
\hline \multicolumn{6}{|l|}{ 1. Objectives, Autonomy, Powers, and Resources } \\
\hline 1.1 Objectives & & & $\mathbf{X}$ & & \\
\hline 1.2 Independence & & & & $\mathbf{X}$ & \\
\hline 1.3 Legal framework & & & & $\mathbf{X}$ & \\
\hline 1.4 Enforcement powers & & & $\mathbf{X}$ & & \\
\hline 1.5 Legal protection & $\mathbf{X}$ & & & & \\
\hline 1.6 Information sharing & & & & $\mathbf{X}$ & \\
\hline 2. Permissible activities & & $\mathbf{X}$ & & & \\
\hline 3. Licensing criteria & & & $\mathbf{X}$ & & \\
\hline 4. Ownership & & & & $\mathbf{X}$ & \\
\hline 5. Investment criteria & & & & $\mathbf{X}$ & \\
\hline 6. Capital adequacy & & & & $\mathbf{X}$ & \\
\hline 7. Credit policies & & & & $\mathbf{X}$ & \\
\hline 8. Loan evaluation and loan-loss provisioning & & & & $\mathbf{X}$ & \\
\hline 9. Large exposure limits & & & & $\mathbf{X}$ & \\
\hline 10. Connected lending & & & & $\mathbf{X}$ & \\
\hline 11. Country risk & & & & $\mathbf{X}$ & \\
\hline 12. Market risks & & & & $\mathbf{X}$ & \\
\hline 13. Other risks & & & & $\mathbf{X}$ & \\
\hline 14. Internal control and audit & & & & $\mathbf{X}$ & \\
\hline 15. Money laundering & & & $\mathbf{X}$ & & \\
\hline 16. On-site and off-site supervision & & & $\mathbf{X}$ & & \\
\hline 17. Bank management contact & & & & $\mathbf{X}$ & \\
\hline 18. Off-site supervision & & & $\mathbf{X}$ & & \\
\hline 19. Validation of supervisory information & & & & $\mathbf{X}$ & \\
\hline 20. Consolidated supervision & & & & & $\mathbf{X}$ \\
\hline 21. Accounting standards & & & $\mathbf{X}$ & & \\
\hline 22. Remedial measures & & & $\mathbf{X}$ & & \\
\hline 23. Globally consolidated supervision & & & & & $\mathbf{X}$ \\
\hline 24. Host country supervision & & & & & $\mathbf{X}$ \\
\hline 25. Supervision over foreign banks' establishments & & & & $\mathbf{X}$ & \\
\hline
\end{tabular}

1/ Compliant.

2/ Largely compliant.

$\underline{3}$ / Materially noncompliant.

4/ Noncompliant.

5/ Not applicable. 


\section{Assessment of the Observance of the IAIS Core Principles}

\section{General}

10. At the request of the Vanuatu Financial Services Commission, the mission undertook an assessment of compliance with the IAIS Insurance Core Principles using the Core Principles Methodology. The assessment was undertaken in the context of the OFC Assessment Program, Module 2. It extended to both the domestic and offshore sectors, since both are covered by the same legislation and subject to supervision within the same institutional framework. The assessment took place in May 2002 and was completed primarily by Gordon Rowell, head of insurance at the Cayman Islands Monetary Authority. The resulting action plan is contained in the appendix to Volume I of this report.

\section{Information and methodology used for assessment}

11. The assessment was based on a review of the relevant legislation and regulations (as described in Volume I) and discussions with the staff of the VFSC (primarily the commissioner), industry bodies (e.g., the Finance Center Association and the associations representing domestic insurers, accountants, and lawyers) and representatives of individual institutions. Immediately before the arrival of the mission, the only person within the VFSC to have direct responsibility for day-to-day supervision of the insurance industry resigned his position, and was subsequently unavailable for meetings with the mission. As a result, discussions had to be held with staff members who were less directly familiar with the issues. In addition, there was relatively little available within the VFSC by way of policy documents and operating guidelines to which the mission could refer. Prior to the mission's arrival, the VFSC had submitted responses to a questionnaire, but this did not represent a self-assessment.

\section{Institutional and macroprudential setting-overview}

12. Responsibility for the supervision of the insurance sector is vested in the VFSC, but the minister of finance retains the authority to license and apply enforcement actions. At the time of the assessment, there was a vacancy for the supervisor of insurance within the VFSC, following the immediate and unexpected resignation of the previous incumbent prior to the mission's arrival.

13. At end-December 2001, 12 domestic insurance companies, 1 underwriting association, 7 insurance agents, 6 brokers, and 15 offshore insurance companies were licensed under the Insurance Act. Of the 13 domestic insurers, 5 were locally incorporated companies subject to home regulation in Vanuatu and 8 were external "foreign branch" operations subject to host regulation. The majority of these companies were based in Australia, Europe, and New Zealand.

14. The domestic insurance market in Vanuatu is small, comprising a mixture of life and nonlife companies that predominantly write property, motor, life, and health insurance. Supervision covers only private insurance, which is largely related to property. Complete market statistics for the year ending 2001 are not available. The only available figures 
for 2001 estimate that gross property premiums of the licensed insurers were approximately Vt 320 million. In general, the domestic market is heavily reliant on overseas reinsurance, particularly for cyclone, flood, and earthquake catastrophe cover. The main domestic distribution channels are through agencies or on a direct basis. All agents, brokers, and salesmen are required to be licensed under the Insurance Act.

15. No data is available publicly, or was provided to the mission, on the type of companies that write offshore insurance business, although the primary market for such companies appears to be Australia, and the business may be linked to investment schemes, rather than traditional insurance products.

\section{Principle-by-principle assessment}

\section{Table 5. Detailed Assessment of Observance of the IAIS Insurance Core Principles}

\section{Principle 1. Organization of an Insurance Supervisor}

The insurance supervisor of a jurisdiction must be organized so that it is able to accomplish its primary task, i.e., to maintain efficient, fair, safe, and stable insurance markets for the benefit and protection of policyholders. It should, at any time, be able to carry out this task efficiently in accordance with the Insurance Core Principles. In particular, the insurance supervisor should:

- be operationally independent and accountable in the exercise of its functions and powers;

- $\quad$ have adequate powers, legal protection, and financial resources to perform its functions and exercise its powers;

- $\quad$ adopt a clear, transparent, and consistent regulatory and supervisory process;

- clearly define the responsibility for decision-making; and

- hire, train, and maintain sufficient staff with high professional standards that follow the appropriate standards of confidentiality.

\begin{tabular}{|l|l|}
\hline Description & $\begin{array}{l}\text { Independence } \\
\text { The Assistant Company Registration and Compliance is also the acting insurance supervisor (the } \\
\text { supervisor of insurance), who is an employee of the VFSC, a regulatory body formed specifically } \\
\text { to regulate, amongst other entities, offshore (exempt) companies, insurance companies, offshore } \\
\text { banks, international companies, and trust companies in Vanuatu. The regulation of the insurance } \\
\text { industry falls under the Insurance Act, which commenced on December 29, 1973. The regulation } \\
\text { of insurance licensees is also subject to the provisions of the Companies Act. The VFSC is a } \\
\text { statutory body that falls under the portfolio of the minister of finance. It has a board of directors } \\
\text { presently comprised of three private sector individuals and two ex-officio members, including the } \\
\text { commissioner of the VFSC and the governor of the RBV. }\end{array}$ \\
\hline
\end{tabular}

The duties and the powers of the supervisor of insurance (and, by extension, the staff) are in most respects prescribed in Section 7 of the Financial Services Commission Act, but are also supplemented within the supervisor's contract of employment.

The Insurance Act provides that the minister responsible for commerce makes all decisions with respect to licensing and regulatory matters, upon advice from the supervisor of insurance.

The supervisor of insurance is offered protection from liability in damages for anything done or omitted in the discharge of any powers or functions in good faith under Section 55 of the Insurance Act. 


\begin{tabular}{|c|c|}
\hline & 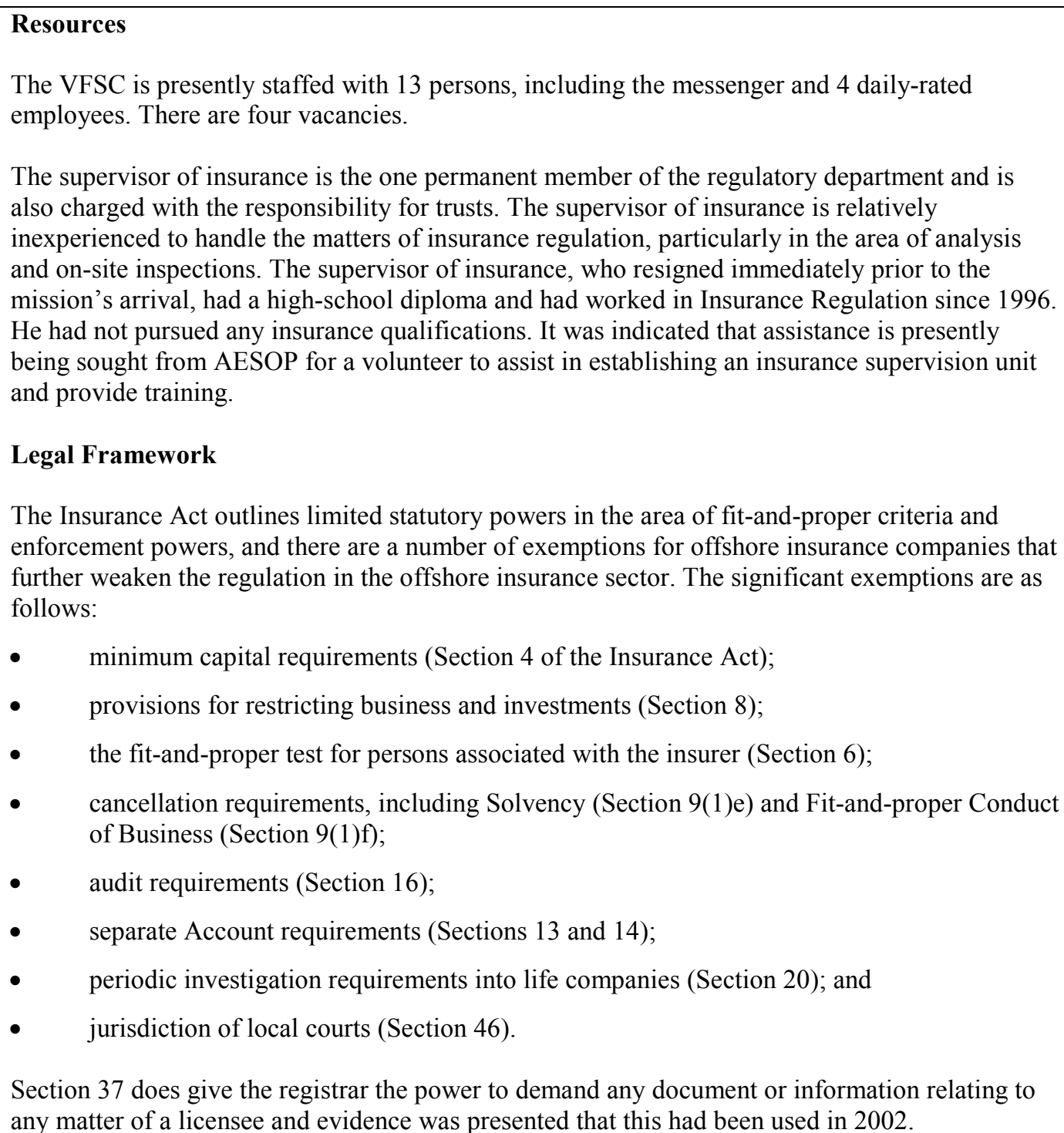 \\
\hline Asses & Materially non-observant \\
\hline Comments & $\begin{array}{l}\text { The regulatory body in charge of insurance regulation does not lend itself to prudent regulation } \\
\text { because there is a lack of independence, an absence of transparency, insufficient expert resources } \\
\text { and a weak legal infrastructure. } \\
\text { The minister of finance makes all decisions with respect to licensing and regulatory matters upon } \\
\text { advice from the supervisor of insurance. There is evidence that operational independence can be } \\
\text { interfered with, and it is not a structure that lends itself to efficiency or operational independence. } \\
\text { The Insurance Act is prescriptive, which facilitates decision-making, but lacks substantive detail. } \\
\text { Apart from the absence of adequate sanctions, there are no application forms prescribed in the } \\
\text { Act. However, application forms have been developed that explain the requirements to be filed } \\
\text { and these appear satisfactory. }\end{array}$ \\
\hline
\end{tabular}




\section{Principle 2. Licensing}

Companies wishing to underwrite insurance in the domestic insurance market should be licensed. Where the insurance supervisor has authority to grant a license, the insurance supervisor:

- $\quad$ in granting a license, should assess the suitability of owners, directors, and/or senior management, and the soundness of the business plan, which could include proforma financial statements, a capital plan, and projected solvency margins; and

- $\quad$ in permitting access to the domestic market, may choose to rely on the work carried out by an insurance supervisor in another jurisdiction if the prudential rules of the two jurisdictions are broadly equivalent.

\begin{tabular}{|c|c|}
\hline Description & $\begin{array}{l}\text { The minister of finance has the legal authority to grant a license under Parts II, III, and IV of the } \\
\text { Insurance Act and the permitted types of legal form are all prescribed in the Act. } \\
\text { The grounds for refusal of a license are specified as follows: } \\
\text { - whenever the minister considers it to be in the public interest, he may refuse the registration } \\
\text { of any insurer and any such decision may be final; }\end{array}$ \\
\hline & $\begin{array}{l}\text { - the minister may refuse the registration of a local } \\
\text { insurer is not a fit-and-proper person to be associ }\end{array}$ \\
\hline
\end{tabular}

The form of application is not defined in the Insurance Act or Company Act either in law or regulation. However, the VFSC has implemented a schedule of their requirements, which include the requirement to file a business plan, the name of the principal and alternate principal, two references, copies of passports, CVs and qualifications of the principals, a police clearance report, statements of assets and liabilities of beneficiaries, and a license fee. The content of a business plan is not defined. According to the VFSC, it is required to assess if an owner or management has sufficient qualifications and is generally fit-and-proper to be involved in the insurance business.

Assessment Materially non-observant

Comments There are material risks for small jurisdictions that seek to attract offshore insurance business, including the probable involvement of foreign residents in some part in the procurement process, the attendant difficulties with due diligence and, possibly a high reputation risk for Vanuatu, should the company fail.

The fit-and-proper test is not defined, only extends to domestic insurers and only extends to officers of the licensee. It was explained that, in practice, due diligence is performed and certain documents were obtained from key functionaries, including a biographical affidavit, passport photograph, police clearance, statement of net assets and liabilities and two references. It was stated that the references were also contacted and the services of the International Chamber of Commerce in the United Kingdom were utilized to carry out checks.

However, it appears that this is not consistently applied in all cases and, in any event, lacks full statutory support. It is evident that there are inconsistencies in the licensing process caused by a lack of awareness and lack of staff. A license should not be issued if it appears that any key functionary of the applicant is not a fit-and-proper person to hold the position held by him. No documented procedures exist that address either the new license procedures or the assessment standards and processes of key functionaries.

The Insurance Act grants the power to issue guidance notes to the insurance sector, but only one guidance note has been issued [on anti-money laundering].

The business plans need to be more developed as they lacked pertinent information as to make an appropriate judgment, particularly in the areas of anti-money laundering measures and the complexity of the business, and there was no evidence of communication with overseas 


\begin{tabular}{|c|c|}
\hline & $\begin{array}{l}\text { authorities. } \\
\text { There are a number of licensing provisions that are not included in the Insurance Act, including } \\
\text { the following critical criteria: } \\
\text { - the form of the application is not transparent within the Act; } \\
\text { - the requirement for offshore insurance companies to maintain a minimum capitalization; } \\
\text { - fit-and-proper criteria for key functionaries other than prescribed in Section 6(3); and } \\
\text { - evidence and supporting documentation of the beneficial and ultimate shareholders of the } \\
\text { applicant. } \\
\text { No legal provisions exist prohibiting the minister of finance from issuing a license to an applicant } \\
\text { if it appears to him that any key functionary of the applicant is not a fit-and-proper person to hold } \\
\text { the position held by him, other than in Section } 6(3) \text { for officers of local insurance companies. } \\
\text { This also includes issuing a license to an applicant if it appears that there is insufficient } \\
\text { knowledge or expertise. }\end{array}$ \\
\hline \multicolumn{2}{|c|}{$\begin{array}{l}\text { Principle 3. Changes in Control } \\
\text { The insurance supervisor should review changes in the control of companies that are licensed in the jurisdiction. The } \\
\text { insurance supervisor should establish clear requirements to be met when a change in control occurs. These may be } \\
\text { the same as, or similar to, the requirements which apply in granting a license. In particular, the insurance supervisor } \\
\text { should: } \\
\text { - require the purchaser or the licensed insurance company to provide notification of the change in control and/or } \\
\text { seek approval of the proposed change; and } \\
\text { establish criteria to assess the appropriateness of the change, which could include the assessment of the } \\
\text { suitability of the new owners as well as any new directors and senior managers, and the soundness of any new } \\
\text { business plan. }\end{array}$} \\
\hline Description & $\begin{array}{l}\text { Section } 11 \text { of the Insurance Act requires that a registered insurer notify the supervisor of } \\
\text { insurance of any new principals, a change of principal office, or the change in name of the } \\
\text { principals within } 20 \text { days of the change. } \\
\text { Section } 21 \text {, which does not apply to offshore insurance companies, provides that no local } \\
\text { insurance company may amalgamate or transfer its insurance business unless the transfer is } \\
\text { sanctioned by the minister. }\end{array}$ \\
\hline Asse & Materially $n$ \\
\hline Comments & $\begin{array}{l}\text { The provisions of Section } 11 \text { are for notification only and do not require prior sanctioning by the } \\
\text { supervisor of insurance, and furthermore do not relate to beneficial or ultimate ownership. This } \\
\text { represents a significant weakness in the regulatory process. } \\
\text { The recommendations noted under Principle } 2 \text { on the due diligence aspect of the licensing } \\
\text { process should apply to a change in control. }\end{array}$ \\
\hline \multicolumn{2}{|c|}{$\begin{array}{l}\text { Principle 4. Corporate Governance } \\
\text { It is desirable that standards be established in the jurisdictions that deal with corporate governance. Where the } \\
\text { insurance supervisor has responsibility for setting requirements for corporate governance, the insurance supervisor } \\
\text { should set requirements with respect to: } \\
\text { - the roles and responsibilities of the board of directors; } \\
\text { - } \quad \text { reliance on other supervisors for companies licensed in another jurisdiction; and } \\
\text { - the distinction between the standards to be met by companies incorporated in his jurisdiction and branch } \\
\text { operations of companies incorporated in another jurisdiction. }\end{array}$} \\
\hline
\end{tabular}




\begin{tabular}{|c|c|}
\hline Description & $\begin{array}{l}\text { There are provisions that can be interpreted to regulate corporate governance in the Insurance Act } \\
\text { (section 9) that refer to "Sound Insurance Principles." } \\
\text { Section } 132 \text { of the Companies Act requires all insurance companies to hold an annual general } \\
\text { meeting. }\end{array}$ \\
\hline Assessment & Non-observant \\
\hline Comments & $\begin{array}{l}\text { While Section } 9 \text { does provide a basis for establishing corporate governance, no further } \\
\text { clarification has been issued in this area to the industry in the form of guidance. The supervisor of } \\
\text { insurance should specify that the governance and control environment must set the culture and } \\
\text { permeate every business activity and operational aspect of the company. This can then be } \\
\text { reviewed as part of an on-site inspection program. }\end{array}$ \\
\hline \multicolumn{2}{|c|}{$\begin{array}{l}\text { Principle 5. Internal Controls } \\
\text { The insurance supervisor should be able to: } \\
\text { - } \quad \text { review the internal controls that the board of directors and management approve and apply, and request } \\
\text { strengthening of the controls where necessary; and } \\
\text { - } \quad \text { require the board of directors to provide suitable prudential oversight, such as setting standards for } \\
\text { underwriting risks and setting qualitative and quantitative standards for investment and liquidity management. }\end{array}$} \\
\hline Description & $\begin{array}{l}\text { There are provisions that can be interpreted to regulate internal controls in the Insurance Act } \\
\text { (section 9), which refer to "Sound Insurance Principles." }\end{array}$ \\
\hline Assessment & Non-observant \\
\hline Comments & $\begin{array}{l}\text { In Vanuatu, companies are too small to justify an internal audit function. However, that does not } \\
\text { prevent companies from conducting business in a sound and prudent manner, as required under } \\
\text { Section } 9 \text { of the Insurance Act. While Section } 9 \text { does provide a basis for establishing the need for } \\
\text { internal controls, no further guidance has been issued to the industry. } \\
\text { No appraisal of internal controls is performed either at the licensing stage or through on-site } \\
\text { inspections. While it is not necessary to expect each company to maintain the same level of } \\
\text { internal controls, the controls maintained by each company must be adequate for, and appropriate } \\
\text { to, the nature and scale of the insurer's business. Where the insurer fails to maintain adequate } \\
\text { internal controls over its business, the supervisor of insurance may take appropriate action, which } \\
\text { might, in extreme circumstances, include the withdrawal of the insurer's license. }\end{array}$ \\
\hline \multicolumn{2}{|c|}{$\begin{array}{l}\text { Principle 6. Assets } \\
\text { Standards should be established with respect to the assets of companies licensed to operate in the jurisdiction. Where } \\
\text { insurance supervisors have the authority to establish the standards, these should apply at least to an amount of assets } \\
\text { equal to the total of the technical provisions, and should address: } \\
\text { - diversification by type; } \\
\text { - any limits, or restrictions, on the amount that may be held in financial instruments, property, and receivables; } \\
\text { - the basis for valuing assets which are included in the financial reports; } \\
\text { - the safekeeping of assets; } \\
\text { - } \quad \text { appropriate matching of assets and liabilities; and }\end{array}$} \\
\hline Description & $\begin{array}{l}\text { Section } 8(2) \text { of the Insurance Act allows the minister of finance to place restrictions on local } \\
\text { domestic insurance companies (which are prohibited from making investments of a specified } \\
\text { class) and may require an insurer to dispose of inappropriate investments within a specified time } \\
\text { period. However, offshore insurance companies are exempt from the provisions of Section } 8(2) \text {. } \\
\text { Section } 13 \text { provides a legislative framework for the separation of business, other than insurance } \\
\text { business, for domestic insurance companies. Section } 14 \text { requires the separation of life insurance } \\
\text { business from nonlife business of domestic insurance companies, including all receipts and } \\
\text { payments. There are no prohibitions in relation to loans for offshore insurance companies. }\end{array}$ \\
\hline & Materially non-observant \\
\hline Comments & \\
\hline
\end{tabular}




\begin{tabular}{|c|c|}
\hline & $\begin{array}{l}\text { management of assets is reasonably straightforward. However, there are some loopholes. } \\
\text { While the minister has limited power to exercise authority over investment strategy, no evidence } \\
\text { was produced that this has taken place. For example, a guidance note or rule could be issued that } \\
\text { states that the statutory assets must be invested in cash (or equivalents), bonds, debentures, } \\
\text { preferred and common stock, GICs, real estate, and mortgages. } \\
\text { No deposit "ring-fencing" provisions exist in the Insurance Act. By requiring foreign operations } \\
\text { to provide for funds to be held in trust, the supervisor of insurance has the additional protection in } \\
\text { the event that an insurance company decides to withdraw from the market. } \\
\text { In terms of reviewing governance and management oversight of the investment strategy, the } \\
\text { auditor is required to certify that the financial return has been prepared in accordance with } \\
\text { international accounting standards. }\end{array}$ \\
\hline \multicolumn{2}{|c|}{$\begin{array}{l}\text { Principle 7. Liabilities } \\
\text { Insurance supervisors should establish standards with respect to the liabilities of companies licensed to operate in } \\
\text { their jurisdiction. In developing the standards, the insurance supervisor should consider: } \\
\text { - what is to be included as a liability of the company, for example, claims incurred but not paid, claims incurred } \\
\text { but not reported, amounts owed to others, amounts owed that are in dispute, premiums received in advance, as } \\
\text { well as the provision for policy liabilities or technical provisions that may be set by an actuary; } \\
\text { - the standards for establishing policy liabilities or technical provisions; and } \\
\text { - the amount of credit allowed to reduce liabilities for amounts recoverable under reinsurance arrangements with } \\
\text { a given reinsurer, making provision for the ultimate collectibility. }\end{array}$} \\
\hline Description & $\begin{array}{l}\text { Section } 20 \text { of the Insurance Act requires that companies carrying on long-term business shall } \\
\text { provide an actuarial valuation of their liabilities every three years. The actuary must make } \\
\text { available a statement of the assumptions and methods used in making the valuation. Offshore } \\
\text { insurance companies are exempt from the provisions of Section } 20 \text {. }\end{array}$ \\
\hline Assessment & Materially non-observant \\
\hline Comments & $\begin{array}{l}\text { There are no provisions within the Insurance Act that prescribe rules on liabilities and the } \\
\text { technical provisions that may be set for nonlife or offshore insurance business. Nor are there any } \\
\text { rules or regulations that prescribe the amount of credit allowed to reduce liabilities for amounts } \\
\text { from reinsurance recoverables. } \\
\text { Generally speaking, the overriding rule is that technical provisions and other liabilities must be } \\
\text { determined in accordance with sound accounting and actuarial principles. This is particularly } \\
\text { important in the area of life insurance, where the provisions for life reserves are more difficult to } \\
\text { judge for the supervisor of insurance. } \\
\text { No actuarial reports are being consistently filed by domestic insurance companies as prescribed } \\
\text { by the Insurance Act. } \\
\text { The insurance supervisor does not check the sufficiency of the technical provisions (policy } \\
\text { liabilities) to ensure that the insurance company can meet any estimated insurance liabilities as } \\
\text { they fall due; and require these provisions (liabilities) to be increased if necessary. As part of the } \\
\text { annual examination of an insurance company's accounts and returns submitted to the supervisor } \\
\text { of insurance, the supervisory team should examine the technical provisions of the company and } \\
\text { considers their adequacy. The Supervisor should, if necessary, discuss with the company any } \\
\text { doubts he may have about the adequacy of these provisions and, could if necessary, require them, } \\
\text { under the powers available to the Supervisor, to be appropriately increased. It is recommended } \\
\text { that this area also be covered by a comprehensive on-site inspection program. } \\
\text { The supervisor of insurance has no power to intervene against a specific reinsurance arrangement } \\
\text { if the reinsurance conditions are not suitable with respect to the insured risks, the premiums that } \\
\text { are ceded, or the suitability of the reinsurance company. }\end{array}$ \\
\hline
\end{tabular}




\begin{tabular}{|c|c|}
\hline \multicolumn{2}{|c|}{$\begin{array}{l}\text { Principle 8. Capital Adequacy and Solvency } \\
\text { The requirements regarding the capital to be maintained by companies which are licensed, or seeking a license, in } \\
\text { the jurisdiction should be clearly defined and should address the minimum levels of capital or the levels of deposits } \\
\text { that should be maintained. Capital adequacy requirements should reflect the size, complexity, and business risks of } \\
\text { the company in the jurisdiction. }\end{array}$} \\
\hline Description & $\begin{array}{l}\text { The determination of technical provisions and assets are dealt with in Principles } 6 \text { and } 7 \\
\text { respectively, in relation to which Vanuatu is materially non-observant. } \\
\text { Section } 4 \text { of the Insurance Act outlines the financial requirements for licensing of domestic } \\
\text { insurance companies, and requires that, inter alia: } \\
\text { - life insurance companies maintain a paid-up share capital of Vt } 30 \text { million; and } \\
\text { - nonlife insurance companies maintain between Vt } 14 \text { million to Vt } 140 \text { million dependent on } \\
\text { the level of premium income. } \\
\text { Section } 9(1) \text { also requires that the free assets of a domestic insurance company are sufficient for } \\
\text { the proper conduct of its insurance business. }\end{array}$ \\
\hline Assessment & Materially non-observant \\
\hline Comn & $\begin{array}{l}\text { There is a risk that too much reliance on minimum margins of solvency will result in capital that } \\
\text { is not many times the exposure of any one loss. Therefore, particular focus should also be made } \\
\text { on the per exposure net and gross retentions relative to capital. } \\
\text { The need to maintain a margin of solvency is not prescribed in the Insurance Act for offshore } \\
\text { insurance companies. Furthermore, no minimum capital requirements are outlined for offshore } \\
\text { insurance companies. There are no controls in place to ensure that an insurer can meet obligations } \\
\text { at all times. } \\
\text { There are no requirements, either in the Insurance Act or in guidance notes, requiring that the } \\
\text { supervisor of insurance have the authority to require that the minimum amount of capital be } \\
\text { covered by unencumbered assets (i.e., not pledged assets). } \\
\text { While the supervisor of insurance has the statutory authority to monitor the level of technical } \\
\text { provisions, the adequate coverage of technical provisions by assets and an additional buffer, this } \\
\text { is presently not being performed to a satisfactory standard. An essential part of the standard } \\
\text { procedure of examining the returns and accounts that the insurer submits annually to the } \\
\text { Supervisor should be to monitor how assets and liabilities have been determined and whether the } \\
\text { minimum capital for domestic insurance companies has been maintained. }\end{array}$ \\
\hline \multicolumn{2}{|c|}{$\begin{array}{l}\text { Principle 9. Derivatives and 'Off-Balance Sheet' Items } \\
\text { The insurance supervisor should be able to set requirements with respect to the use of financial instruments that may } \\
\text { not form a part of the financial report of a company licensed in the jurisdiction. In setting these requirements, the } \\
\text { insurance supervisor should address: } \\
\text { - } \quad \text { restrictions in the use of derivatives and other off-balance sheet items; } \\
\text { - disclosure requirements for derivatives and other off-balance sheet items; and } \\
\text { - the establishment of adequate internal controls and monitoring of derivative positions. }\end{array}$} \\
\hline Description & $\begin{array}{l}\text { Section } 8(2) \text { of the Insurance Act empowers the minister of finance to make restrictions on } \\
\text { investments by a domestic insurance company. } \\
\text { There are no such restrictions in place for offshore insurance companies. }\end{array}$ \\
\hline Assessment & Not applicable \\
\hline Comments & $\begin{array}{l}\text { Vanuatu is a very small insurance market and, to date, insurance companies licensed in Vanuatu } \\
\text { do not appear to have used derivatives, although this could not be verified. The minister of } \\
\text { finance has not issued any restrictions on investments. }\end{array}$ \\
\hline
\end{tabular}




\section{Principle 10. Reinsurance}

Insurance companies use reinsurance as a means of risk containment. The insurance supervisor must be able to review reinsurance arrangements, to assess the degree of reliance placed on these arrangements and to determine the appropriateness of such reliance. Insurance companies would be expected to assess the financial positions of their reinsurers in determining an appropriate level of exposure to them.

The insurance supervisor should set requirements with respect to reinsurance contracts or reinsurance companies addressing:

- the amount of the credit taken for reinsurance ceded. The amount of credit taken should reflect an assessment of the ultimate collectibility of the reinsurance recoverable and may take into account the supervisory control over the reinsurer; and

- the amount of reliance placed on the insurance supervisor of the reinsurance business of a company that is incorporated in another jurisdiction.

\begin{tabular}{|l|l|}
\hline Description & $\begin{array}{l}\text { Reinsurers, which can be licensed in Vanuatu, are subject to the same supervision and licensing } \\
\text { as a direct insurer, whether or not they act as a primary insurer. }\end{array}$ \\
\hline Assessment & Non-observant \\
\hline Comments & $\begin{array}{l}\text { Vanuatu is a very small insurance market but has great exposure to cyclones, earthquakes, and } \\
\text { flooding. As such, catastrophe reinsurance is important to the integrity of the market. Presently, } \\
\text { there is too much reliance placed on the insurance companies to self-determine the proper level of } \\
\text { catastrophe coverage and, as such, there is a high risk of an insurer retaining too much risk. This } \\
\text { is particularly true for local domestic insurance companies. }\end{array}$
\end{tabular}

As discussed in Principle 2, there are no requirements that outline the content of the business plan with respect to reinsurance arrangements, and there are no statutory requirements that refer to the adequacy of reinsurance, the exposure to reinsurance, and the credit taken for reinsurance ceded.

Presently, no member of the regulatory staff has adequate knowledge of reinsurance arrangements, and no formal procedure or checklist exists for providing an analysis of the reinsurance treaties in place. No analysis was evident as to what information is examined and in what context. For example, there is no evidence that the company's maximum retention per risk or probable maximum loss, either in isolation or relative to capital and surplus, is assessed.

\section{Principle 11. Market Conduct}

Insurance supervisors should ensure that insurers and intermediaries exercise the necessary knowledge, skills, and integrity in dealing with their customers.

Insurers and intermediaries should:

- $\quad$ at all times act honestly and in a straightforward manner;

- $\quad$ act with due skill, care, and diligence in conducting their business activities;

- $\quad$ conduct their business and organize their affairs with prudence;

- $\quad$ pay due regard to the information needs of their customers and treat them fairly;

- $\quad$ seek from their customers information which might reasonably be expected before giving advice or concluding a contract;

- $\quad$ avoid conflicts of interest;

- deal with their regulators in an open and cooperative way;

- $\quad$ support a system of complaints handling, where applicable; and

- $\quad$ organize and control their affairs effectively. 


\begin{tabular}{|c|c|}
\hline Description & $\begin{array}{l}\text { Section } 26 \text { of the Insurance Act addresses the area of fit-and-proper within the legal provisions } \\
\text { for local insurance agents. Section } 26 \text { requires that all agents, brokers, and salesmen are of good } \\
\text { character and also sufficiently competent and knowledgeable to carry on business for the } \\
\text { respective class of business they are selling. } \\
\text { There are limited policyholder protection provisions in Sections } 12 \text { and } 45 \text { of the Act relating to } \\
\text { cancellation of a policy, the protection against the insurer not receiving premiums from the agent, } \\
\text { misleading advertising, the surrender of policies, and carrying on business in a proper fashion. }\end{array}$ \\
\hline Assessment & Materially non-observant \\
\hline Comments & $\begin{array}{l}\text { While some requirements that customers be treated fairly are set out in the Insurance Act, there is } \\
\text { little evidence that intermediaries are being regulated and the provisions being monitored. } \\
\text { It is recommended that a full review of regulatory practices with respect to intermediaries be } \\
\text { carried out, particularly to determine how to effectively monitor the effect of this legislation. }\end{array}$ \\
\hline \multicolumn{2}{|c|}{$\begin{array}{l}\text { Principle 12. Financial Reporting } \\
\text { It is important that insurance supervisors get the information they need to properly form an opinion on the financial } \\
\text { strength of the operations of each insurance company in their jurisdiction. The information needed to carry out this } \\
\text { review and analysis is obtained from the financial and statistical reports that are filed on a regular basis, supported } \\
\text { by information obtained through special information requests, on-site inspections, and communication with actuaries } \\
\text { and external auditors. } \\
\text { A process should be established for: } \\
\text { - } \quad \text { setting the scope and frequency of reports requested and received from all companies licensed in the } \\
\text { jurisdiction, including financial reports, statistical reports, actuarial reports, and other information; } \\
\text { - } \quad \text { setting the accounting requirements for the preparation of financial reports in the jurisdiction; } \\
\text { - } \quad \text { ensuring that external audits of insurance companies operating in the jurisdiction are acceptable; and } \\
\text { - } \quad \text { etting the standards for the establishment of technical provisions or policy and other liabilities to be included } \\
\text { In so doing, a distinction may be made: } \\
\text { - between the standards that apply to reports and calculations prepared for disclosure to policyholders and } \\
\text { investors, and those prepared for the insurance supervisor; and } \\
\text { between the financial reports and calculations prepared for companies incorporated in the jurisdiction, and } \\
\text { branch operations of companies incorporated in another jurisdiction. }\end{array}$} \\
\hline Des & $\begin{array}{l}\text { The accounts of a domestic insurance company are required to be filed annually under Section } 16 \\
\text { of the Insurance Act, while offshore insurance companies are exempt from these provisions of the } \\
\text { Act. The accounts must be audited by an independent auditor and properly prepared in } \\
\text { accordance with sound insurance principles. The supervisor of insurance has the power under } \\
\text { Section } 16(3) \text { of the Act to require an insurer to furnish such further particulars as may be } \\
\text { prescribed in the rules. } \\
\text { Section } 17 \text { requires that a domestic insurance company provide, within six-months of year-end, a } \\
\text { certified copy of the audited balance sheet and accounts showing the financial position of all } \\
\text { insurance business, and any such documents and information as prescribed by the rules. } \\
\text { Section } 17(2) \text { requires a copy of any report on the affairs of the domestic insurance company } \\
\text { submitted to policyholders or shareholders. Section } 17(3) \text { requires these statements to be made } \\
\text { public. Offshore insurance companies are exempt from the provisions of Section } 17 \text {. } \\
\text { While offshore insurance companies are exempt from all the filing requirements of the Insurance } \\
\text { Act, they are required to file audited financial statements on a consolidated basis or solo basis } \\
\text { under Section } 377 \text { of the Companies Act. }\end{array}$ \\
\hline
\end{tabular}




\begin{tabular}{|c|c|}
\hline & $\begin{array}{l}\text { Section } 166 \text { of the Companies Act also indicates who can be approved to audit an exempt } \\
\text { company. } \\
\text { Section } 37 \text { of the Insurance Act grants the supervisor of insurance the power to require an insurer } \\
\text { to furnish him, at specified times or intervals, with information about specified matters being, if } \\
\text { he so requires, information verified in a specified manner. However, there was no evidence } \\
\text { presented that this power has been used in the context of financial reporting. } \\
\text { Section } 20 \text { requires companies writing long-term business to provide an actuarial valuation report } \\
\text { of its liabilities every three years. }\end{array}$ \\
\hline Assessment & Materially non-observant \\
\hline Comments & $\begin{array}{l}\text { An advantage of a strong financial reporting environment is the availability of statistical data on } \\
\text { the insurance market, which would be useful to prospective licensees as well as existing } \\
\text { licensees. A strong reporting environment is also critical in Vanuatu because it is presently the } \\
\text { sole method for ongoing supervision of licensees. } \\
\text { While Section } 20 \text { requires the submission of an actuarial valuation report, no evidence was on file } \\
\text { that this was consistently received. } \\
\text { The financial reporting environment is weak principally because little analysis is performed and } \\
\text { the reports that are submitted are limited in the information that they provide. While some useful } \\
\text { financial information is submitted to the supervisor of insurance, no efforts appear to have been } \\
\text { made to examine the audited financial statements. With the lack of a comprehensive procedure } \\
\text { manual or checklist, there is a risk that statutory returns will not be reviewed in a consistent } \\
\text { fashion. In addition, no effective evaluation of reinsurance exposures is consistently performed. }\end{array}$ \\
\hline \multicolumn{2}{|c|}{$\begin{array}{l}\text { Principle 13. On-site Inspection } \\
\text { The insurance supervisor should be able to: } \\
\text { - carry out on-site inspections to review the business and affairs of the company, including the inspection of } \\
\text { books, records, accounts, and other documents. This may be limited to the operation of the company in the } \\
\text { jurisdiction or, subject to the agreement of the respective supervisors, include other jurisdictions in which the } \\
\text { company operates; and } \\
\text { request and receive any information from companies licensed in its jurisdiction, whether this information be } \\
\text { specific to a company or be requested of all companies. }\end{array}$} \\
\hline Description & $\begin{array}{l}\text { Section } 39 \text { of the Insurance Act allows for the application of on-site inspections, but this process } \\
\text { has never been implemented. } \\
\text { Section } 37 \text { allows the supervisor of insurance to demand from a registered insurer, agent, broker } \\
\text { or salesmen or applicant any document or information relating to any matter connected with his } \\
\text { insurance business or transactions. }\end{array}$ \\
\hline Assessment & Non-observant \\
\hline Comments & $\begin{array}{l}\text { The Vanuatu system of insurance supervision is based on traditional off-site supervisory } \\
\text { methods, including the filing of audited accounts, the submission of a director's report, and } \\
\text { notification of the appointment of officers. No on-site inspections have been performed. This is of } \\
\text { particular concern in the area of offshore insurance business, where there is little in the way of } \\
\text { enforceable regulation. } \\
\text { Full on-site inspections represent an invaluable asset to the supervisor in the prudential } \\
\text { supervision of insurers and insurance intermediaries. The on-site inspections also are a check on } \\
\text { the other IAIS Core Principles, especially in the areas of corporate governance, internal controls } \\
\text { and anti-money laundering. } \\
\text { Section } 39 \text { of the Insurance Act does not appear to allow the outsourcing of on-site inspections. }\end{array}$ \\
\hline
\end{tabular}




\section{Principle 14. Sanctions}

Insurance supervisors must have the power to take remedial action where problems involving licensed companies are identified. The insurance supervisor must have a range of actions available in order to apply appropriate sanctions to problems encountered. The legislation should set out the powers available to the insurance supervisor and may include:

- the power to restrict the business activities of a company, for example, by withholding approval for new activities or acquisitions;

- the power to direct a company to stop practices that are unsafe or unsound, or to take action to remedy an unsafe or unsound business practice; and

- the option to invoke other sanctions on a company or its business operation in the jurisdiction, for example, by revoking the license of a company or imposing remedial measures where a company violates the insurance laws of the jurisdiction.

\begin{tabular}{|l|l}
\hline Description & $\begin{array}{l}\text { There is a very limited range of powers available to the supervisor of insurance under Section } 9 \\
\text { of the Insurance Act, which requires the minister to only cancel the insurance license for any of } \\
\text { the following reasons: }\end{array}$
\end{tabular}

(a) the licensee has ceased or not commenced carrying-on business;

(b) the minister is not satisfied that there are sufficient free assets for the safe conduct of business;

(c) insurance business is not being conducted in accordance with sound insurance principles;

(d) voluntary liquidation;

(e) the license was procured from false, misleading, or inaccurate information;

(f) in the case of a company that carries on some form of business in addition to insurance business, that business is likely to be contrary to the public interest; and

(g) the licensee has contravened any provision of the Insurance Act, e.g., filing statutory returns late.

It should be noted that Section (a), (b), and (c) only apply to domestic insurance companies.

Section 52 of the Insurance Act provides for imprisonment and fines for gross contraventions of the Act.

Section 377(2) of the Companies Act provides that if the audited financial statements for an offshore insurance company are not filed within 14 days, the company and every officer shall be liable to a default fine. However, there was no evidence of what the fine is and whether it is enforced.

The intervention powers available to the Supervisor are equally limited as follows:

(a) Section 8 allows the minister to set restrictions on investments for domestic insurance companies;

(b) Section 8 allows the minister to limit or prohibit a domestic insurer from writing new policies;

(c) Section 39 allows the minister to appoint inspectors to investigate the affairs of an insurer; and

(d) Section 37 allows the supervisor to demand such information as he may specify. 


\begin{tabular}{|c|c|}
\hline \multirow{2}{*}{$\begin{array}{l}\text { Assessment } \\
\text { Comments }\end{array}$} & aterially non-observant. \\
\hline & \\
\hline \multicolumn{2}{|c|}{$\begin{array}{l}\text { Principle 15. Cross-Border Business Operations } \\
\text { Insurance companies are becoming increasingly international in scope, establishing branches and subsidiaries } \\
\text { outside their home jurisdiction, and sometimes conducting cross-border business on a services basis only. The } \\
\text { insurance supervisor should ensure that: } \\
\text { - } \quad \text { no foreign insurance establishment escapes supervision; } \\
\text { - } \quad \text { all insurance establishments of international insurance groups and international insurers are subject to effective } \\
\text { supervision; } \\
\text { - } \quad \text { the creation of a cross-border insurance establishment is subject to consultation between host and home } \\
\text { supervisors; and } \\
\text { - foreign insurers providing insurance cover on a cross-border services basis are subject to effective supervision. }\end{array}$} \\
\hline Description & \\
\hline Assessment & \\
\hline Comn & \\
\hline \multirow{6}{*}{\multicolumn{2}{|c|}{$\begin{array}{l}\text { Principle 16. Coordination and Cooperation } \\
\text { Increasingly, insurance supervisors liaise with each other to ensure that each is aware of the other's concerns with } \\
\text { respect to an insurance company that operates in more than one jurisdiction, either directly or through a separate } \\
\text { corporate entity. } \\
\text { In order to share relevant information with other insurance supervisors, adequate and effective communication } \\
\text { should be developed and maintained. } \\
\text { In developing or implementing a regulatory framework, consideration should be given to whether the insurance } \\
\text { supervisor: } \\
\text { - is able to enter into an agreement or understanding with any other supervisor both in other jurisdictions and in } \\
\text { other sectors of the industry (i.e., insurance, banking, or securities) to share information or otherwise work } \\
\text { together; } \\
\text { - is permitted to share information, or otherwise work together, with an insurance supervisor in another } \\
\text { jurisdiction. This may be limited to insurance supervisors who have agreed, and are legally able, to treat the } \\
\text { information as confidential; } \\
\text { - should be informed of findings of investigations where power to investigate fraud, money laundering, and other } \\
\text { such activities rests with a body other than the insurance supervisor; and } \\
\text { is permitted to set out the types of information and the basis on which information obtained by the insurance } \\
\text { supervisor may be shared. }\end{array}$}} \\
\hline & \\
\hline & \\
\hline & \\
\hline & \\
\hline & \\
\hline Description & $\begin{array}{l}\text { Jateway" provisions do not exist in the Insurance Act and are not explicit in the Companies Act. } \\
\text { ction } 381(3) \text { of the Companies Act provides that a liquidator appointed by the court may, upon } \\
\text { quest in writing of a public officer in any country or territory and with the consent of the }\end{array}$ \\
\hline
\end{tabular}




\begin{tabular}{|c|c|}
\hline & $\begin{array}{l}\text { attorney general, disclose to such public officer information with respect to the affairs of an } \\
\text { offshore insurance company. }\end{array}$ \\
\hline Assessment & Materially non-observant \\
\hline Comments & $\begin{array}{l}\text { While "gateway" provisions do not exist in the Insurance Act and are not explicit in the } \\
\text { Companies Act, cooperation does in practice take place, but on an informal basis, and it is unclear } \\
\text { as to what information can be shared or if there are limitations. This applies not only to cross } \\
\text { border cooperation but also internally with respect to cooperation between the VFSC and the } \\
\text { RBV, which would benefit from a formal MOU. } \\
\text { The VFSC has not entered into an agreement or understanding with any other supervisor either in } \\
\text { other jurisdictions or in other sectors of the industry (i.e., insurance, banking, or securities) to } \\
\text { share information or otherwise work together. } \\
\text { There is no formal mechanism to ensure that another body responsible for investigating fraud or } \\
\text { money laundering will inform the supervisor of insurance about an investigation that is taking } \\
\text { place into an insurer licensed and supervised by the VFSC. The authorities have stated that it has } \\
\text { always been government policy that any department or agency that may be affected by a } \\
\text { particular action or decision must be informed, and they believe that this has always been the case } \\
\text { with respect to any investigations into a licensed insurer. The VFSC has assisted other authorities } \\
\text { in the past and is continuing to do so in money laundering and fraud investigation involving } \\
\text { companies or individuals, and also assists in conducting due diligence on behalf of other } \\
\text { authorities. However, the mission believes that there should be routine scheduled meetings } \\
\text { between the VFSC and the FIU to build on this relationship. } \\
\text { A centralized regulatory authority would help to resolve some of these matters. }\end{array}$ \\
\hline \multicolumn{2}{|c|}{$\begin{array}{l}\text { Principle 17. Confidentiality } \\
\text { All insurance supervisors should be subject to professional secrecy constraints in respect of information obtained in } \\
\text { the course of their activities, including during the conduct of on-site inspections. } \\
\text { The insurance supervisor is required to hold confidential any information received from other insurance supervisors, } \\
\text { except where constrained by law or in situations where the insurance supervisor who provided the information } \\
\text { provides authorization for its release. }\end{array}$} \\
\hline \multicolumn{2}{|c|}{$\begin{array}{l}\text { Jurisdictions whose confidentiality requirements continue to constrain or prevent the sharing of information for } \\
\text { supervisory purposes with insurance supervisors in other jurisdictions, and jurisdictions where information received } \\
\text { from another insurance supervisor cannot be kept confidential, are urged to review their requirements. }\end{array}$} \\
\hline Description & $\begin{array}{l}\text { While confidentiality is not defined in the Insurance Act, contracts of employment are explicit in } \\
\text { terms of the provision of Official Secrets Act and Section } 381 \text { of the Companies Act. The } \\
\text { Companies Act provides that information on offshore insurance companies may not be disclosed } \\
\text { at any time, except by court order. However, certain information could be disclosed to other } \\
\text { regulatory bodies for supervisory purposed only. }\end{array}$ \\
\hline Assessment & Observant \\
\hline Comments & $\begin{array}{l}\text { It is recommended that provisions be placed in the Insurance Act that confirm what information } \\
\text { can be shared between other regulatory bodies on a confidential basis. }\end{array}$ \\
\hline
\end{tabular}


Table 6. Summary of Observance of International Association of Insurance Supervisors (IAIS) Core Principles

\begin{tabular}{|c|c|c|c|c|c|c|}
\hline \multirow[b]{2}{*}{$\begin{array}{l}\text { Core } \\
\text { Principle } \\
\text { (CP) }\end{array}$} & \multirow[b]{2}{*}{ Principle } & \multicolumn{5}{|c|}{ Degree of Observance } \\
\hline & & $\begin{array}{c}\text { Observant } \\
\text { (FO) }\end{array}$ & $\begin{array}{c}\text { Largely } \\
\text { Observant } \\
\text { (LO) }\end{array}$ & $\begin{array}{c}\text { Materially } \\
\text { Non- } \\
\text { Observant } \\
\text { (MNO) }\end{array}$ & $\begin{array}{c}\text { Non- } \\
\text { Observant } \\
\text { (NO) }\end{array}$ & $\begin{array}{c}\text { Not } \\
\text { Applicable } \\
\text { (NA) }\end{array}$ \\
\hline & Organization of Insurance Supervisor & & & & & \\
\hline 1. & Organization & & & $\mathbf{X}$ & & \\
\hline & Licensing and Changes in Control & & & & & \\
\hline 2. & Licensing & & & $\mathbf{X}$ & & \\
\hline 3. & Changes in control & & & $\mathbf{X}$ & & \\
\hline & Corporate Governance & & & & & \\
\hline 4. & Corporate governance & & & & $\mathbf{X}$ & \\
\hline & Internal Controls & & & & & \\
\hline 5. & Internal controls & & & & $\mathbf{X}$ & \\
\hline & Prudential Rules & & & & & \\
\hline 6. & Assets & & & $\mathbf{X}$ & & \\
\hline 7. & Liabilities & & & $\mathbf{X}$ & & \\
\hline 8. & Capital adequacy and solvency & & & $\mathbf{X}$ & & \\
\hline 9. & Derivatives and off-balance sheet items & & & & & $\mathbf{X}$ \\
\hline 10. & Reinsurance & & & & $\mathbf{X}$ & \\
\hline & Market Conduct & & & & & \\
\hline 11. & Market Conduct & & & $\mathbf{X}$ & & \\
\hline & Monitoring, Inspection, and Sanctions & & & & & \\
\hline 12. & Financial reporting & & & $\mathbf{X}$ & & \\
\hline 13. & On-site inspection & & & & $\mathbf{X}$ & \\
\hline 14. & Sanctions & & & $\mathbf{X}$ & & \\
\hline & Cross-Border Business Operations & & & & & \\
\hline 15. & Cross-border business operations & & & $\mathbf{X}$ & & \\
\hline & $\begin{array}{l}\text { Coordination, Cooperation, and } \\
\text { Confidentiality }\end{array}$ & & & & & \\
\hline 16. & Coordination and cooperation & & & $\mathbf{X}$ & & \\
\hline 17. & Confidentiality & $\mathbf{X}$ & & & & \\
\hline
\end{tabular}

\section{ASSESSMENT OF LEgal, InStitutional, AND SUPERVISORY ASPECTS OF AML/CFT}

\section{General}

16. The AML/CFT assessment was undertaken at the request of the authorities in Vanuatu, using the April version of the draft IMF/World Bank methodology, ${ }^{1}$ and was in the context of the OFC Assessment Program, Module 2. The assessment took place in May 2002, and was undertaken primarily by Cecilia Marian, Legal Department, in conjunction with the financial sector experts on the mission. The mission also benefited from the input of

${ }^{1}$ Since the assessment was undertaken, this has been superseded (in October 2002) by a revised methodology agreed between the FATF, the IMF, and the World Bank. 
Ms. Pat O'Sullivan, an IMF consultant, who was in Vanuatu at the same time pursuing the technical assistance program to develop a regional FIU. The resulting recommended action plan from the assessment is contained in the appendix to Volume I of the report.

\section{Information and methodology used for assessment}

17. The assessment was based on a review of the legislation and regulations in force, and guidance notes and policy statements issued by the authorities (as described in Volume I), as well as discussions with the staff of the FIU; government law officers; the police; the regulatory authorities (the Reserve Bank of Vanuatu and the Vanuatu Financial Services Commission); and industry bodies (e.g., the Finance Center Association and associations representing the bankers, accountants, and lawyers). The mission also discussed practical implementation procedures with representatives of private sector institutions. In advance of the mission's arrival, the authorities had submitted responses to questionnaires on the AML/CFT regime, but this did not constitute a detailed self-assessment.

\section{Institutional framework-overview}

18. The Financial Transactions Reporting Act gives a pivotal role to the FIU established in the State Law Office. Its functions are to:

- $\quad$ receive suspicious transaction reports (STRs) given by financial institutions;

- $\quad$ disseminate STRs to law enforcement and regulatory agencies;

- $\quad$ conduct investigations to ensure compliance with the Act;

- $\quad$ receive information from domestic and foreign regulatory or law enforcement bodies in relation to the investigation or prosecution of money laundering;

- $\quad$ issue guidelines regarding record-keeping and reporting obligations; and

- $\quad$ provide training programs for financial institutions about record-keeping and reporting obligations.

19. The financial regulators have played a minimal role in enforcing the AML requirements in the banking sector, although the RBV has been developing its supervisory role in this area. The offshore banking, insurance, and trust companies' sectors are not currently subject to effective supervision, while company service providers, money remitters, and moneychangers fall outside any regulatory regime.

20. The Vanuatu Police Force is responsible for investigating money-laundering offences while the public prosecutor is responsible for prosecutions of money-laundering offences. To date, there have been no prosecutions. The attorney general is responsible for international cooperation on money-laundering matters. 


\title{
Part 1: Adequacy of the Legal and Institutional AML/CFT Elements
}

\author{
Table 7. Detailed Assessment of the Legal and Institutional AML/CFT Elements
}

\begin{tabular}{|c|c|}
\hline \multicolumn{2}{|c|}{$\begin{array}{l}\text { Principle 1. Legal Requirements for Financial Service Providers (FSP) } \\
\text { 1a. Customer due diligence } \\
\text { FSP should be required to identify, on the basis of an official identifying document, and to record the identity of their } \\
\text { customers, either occasional or usual, when establishing business relations or conducting transactions, and to renew } \\
\text { identification when doubts appear as to their identity in the course of their business relationship. }{ }^{2}\end{array}$} \\
\hline Description & $\begin{array}{l}\text { Section } 10 \text { of the Financial Transactions Reporting Act } 2000 \text { (FTRA) requires financial institutions } \\
\text { to verify customers' identity. } \\
\text { Section } 10 \text { also requires financial institutions to verify not only the identity of the person conducting } \\
\text { the transaction, but the identity of the other person or persons for whom, or for whose ultimate } \\
\text { benefit, the transaction is being conducted, where it has reasonable grounds for believing that the } \\
\text { person is conducting the transaction on behalf of any other person or persons. } \\
\text { The requirement to verify a customer, as set out above, arises when a person conducts a transaction } \\
\text { through a financial institution, and the amount of transaction exceeds Vt } 1 \text { million. The definition of } \\
\text { "transaction' in the FTRA does not include opening an account. } \\
\text { Section } 16 \text { of the FTRA prohibits false name accounts. } \\
\text { "Financial institution" is widely defined in section } 2 \text { to include domestic and offshore banks; } \\
\text { domestic and offshore insurers; nonbank financial institutions; lawyers; and accountants; when } \\
\text { dealing with money. } \\
\text { Section } 53 \text { of the Financial Institutions Act } 1999 \text { prohibits domestic banks from undertaking } \\
\text { transactions if they doubt the authenticity of documents or the truth of statements material to the } \\
\text { transaction, or suspect or know that the funds involved in the transaction have been obtained from } \\
\text { illegal activity. The Act also requires domestic banks to verify the true identity of the person in the } \\
\text { case of suspicious transactions. Section } 52 \text { of the Financial institutions Act also requires domestic } \\
\text { banks to retain copies of checks, bank drafts bills of exchange, or promissory notes for six years. }\end{array}$ \\
\hline Assess & Materially no \\
\hline Con & $\begin{array}{l}\text { The FTRA does not statutorily require financial institutions to identify a customer when opening an } \\
\text { account. Although the Guidelines for Financial Institutions issued by the FIU states that identity } \\
\text { must be verified where people are applying to become account holders for the first time, it has no } \\
\text { legal basis. } \\
\text { The requirement to verify customers in section } 10 \text { only arises if a person conducts a transaction } \\
\text { through a financial institution and the transaction is above Vt } 1 \text { million. There is a threshold attached } \\
\text { to the verification requirement and it does not cover occasional customers. } \\
\begin{array}{l}\text { Under section } 10 \text { (4) of the Financial Transaction Reporting Act and the guidelines, the customer- } \\
\text { identification requirement is not required for those transactions that are conducted through another } \\
\text { financial institution. For example, if a lawyer or an accountant, acting as a financial intermediary, } \\
\text { performs a banking transaction for a client abroad, a bank is not legally required to seek the relevant }\end{array}\end{array}$ \\
\hline
\end{tabular}

\footnotetext{
${ }^{2}$ Financial service providers should ensure that the criteria relating to customer due diligence are also applied to branches and majority-owned subsidiaries located abroad, subject to local laws and regulations.
} 
identification information on that client. Section 10 (4) also waives customer identification for any transaction that is part of any established business relationship with a person who has already produced satisfactory evidence of identity.

The customer identification requirement has been applied only to those transactions and business relationships entered into after the passage of the FTRA in September 2000 (see the Guidelines for Financial Institutions).

The FTRA and the Guidelines for Financial Institutions issued by the FIU lack clarity on what identification documents are acceptable for the identification of individual as well as corporate customers.

There is no legislation that specifically requires financial intermediaries to include originator information and related messages on funds transfers. The government has no plan to introduce such a requirement.

\section{Principle 1. Legal Requirements for Financial Service Providers (FSP)}

\section{1b. Record-keeping}

FSP should be required to maintain records on customer identity and of customer transactions for at least five years following the termination of an account or business relationship, and following the completion of the transaction, respectively, for at least five years (or longer if requested by an authorized government official). These documents should be available for inspection by authorized government officials.

\begin{tabular}{l|l}
\hline Description & $\begin{array}{l}\text { The FTRA requires financial institutions to keep customer identification records (section 11), as well } \\
\text { as transaction records (section 9). The records of every transaction that are kept should be those that } \\
\text { are reasonably necessary to enable the transaction to be readily reconstructed at any time by the FIU. }\end{array}$ \\
& $\begin{array}{l}\text { Under section 11 (2) of the FTRA, identification records must be kept for six years after they were } \\
\text { obtained. Similarly, section 9 (3) of the FTRA requires a financial institution to keep the transaction } \\
\text { records for six years after the completion of the transaction. }\end{array}$ \\
\hline Assessment & Largely compliant \\
\hline Comments & $\begin{array}{l}\text { The prescribed period for the retention of identification records should commence after the } \\
\text { transactions or business relations have ceased. }\end{array}$ \\
\hline
\end{tabular}

Principle 1. Legal Requirements for Financial Service Providers (FSP)

\section{1c. Suspicious transactions reporting}

The FSP should be required to scrutinize (i) all complex or unusual transactions, and complex or unusual patterns of transactions, that have no apparent or visible economic or lawful purpose, and to make available their findings in writing to authorized government officials; (ii) transactions with persons in jurisdictions that do not have adequate systems in place to prevent or deter ML or FT; and (iii) funds transfers that do not contain originator information. If an FSP suspects that assets in a transaction either stem from criminal activity or is to be used to finance terrorism, the FSP should be required to make a suspicious transaction report (STR) to the FIU.

\begin{tabular}{l|l} 
Description & The FTRA requires financial institutions to report suspicious transactions to the FIU (section 5).
\end{tabular} "Financial institution" is widely defined in section 2 to include domestic and offshore banks; domestic and offshore insurers; nonbank financial institutions; lawyers; accountants; when dealing with money.

Section 7 of the FTRA, together with section 4 (2) in the same Act, provides protection to persons reporting suspicious transactions.

Section 6 of the FTRA prohibits and criminalizes "tipping off." An amendment to the Serious Offences Act has been proposed to criminalize financing of terrorism as one of the serious offences. Regulations under the FTRA require financial institutions to report those transactions suspected of being linked to terrorist financing.

Section 4 (2) of the FTRA provides that the provisions of this Act would prevail over the provisions of any other Act and, thereafter, confidentiality and secrecy provisions in other laws would be overridden. 


\begin{tabular}{|c|c|}
\hline Assessment & argely compliant \\
\hline Comments & $\begin{array}{l}\text { Although guidelines for financial institutions issued by the FIU provide a number of examples of } \\
\text { suspicious transactions, the authorities have not yet issued any regulation requiring financial } \\
\text { institutions to pay special attention to those transactions with persons in jurisdictions that have } \\
\text { inadequate AML regimes. } \\
\text { The protection under section } 7 \text { of the FTRA is limited to STRs made, and any other information } \\
\text { provided, in relation to that STR. If a financial institution makes any other disclosure under the } \\
\text { FTRA, it is not protected. } \\
\text { The authorities have not yet issued any regulation requiring financial institutions to scrutinize funds } \\
\text { transfers that do not contain originator information. The FTRA provides that STRs made by } \\
\text { domestic and offshore banks are provided to the RBV. STRs made by offshore banks are only } \\
\text { provided to the VFSC, if the attorney general thinks it appropriate. } \\
\text { It is proposed that the FTRA be amended so that the RBV is provided with STRs relating to } \\
\text { domestic banks, where the attorney general thinks it appropriate. } \\
\text { While section } 4 \text { (2) of the FTRA clearly provides that the FTRA overrides any other Act, the FTRA } \\
\text { should be amended to specifically provide that it overrides any banking or other secrecy provisions } \\
\text { to prevent any ambiguity. } \\
\text { Auditors and the VFSC should be included as a financial institution under FTRA and be obliged to } \\
\text { report STRs. }\end{array}$ \\
\hline \multicolumn{2}{|c|}{$\begin{array}{l}\text { Principle 1. Legal Requirements for Financial Service Providers (FSP) } \\
\text { 1d. } A M L / C F T \text { internal controls } \\
\text { Regulated financial institutions should be required to establish and maintain internal procedures to prevent their } \\
\text { institutions from being used for ML or FT purposes. }\end{array}$} \\
\hline Description & $\begin{array}{l}\text { Section } 8 \text { (1) of the FTRA requires a financial institution to establish and maintain internal } \\
\text { procedures for the prevention of money laundering. In accordance with section } 8 \text { (2), a written } \\
\text { statement of those procedures must be submitted to the FIU. } \\
\text { The RBV issued a notice to domestic banks in July 2000, requiring the development of internal } \\
\text { policies and the training of employees. }\end{array}$ \\
\hline Asses & argely compliant. \\
\hline Coms & $\begin{array}{l}\text { Neither the FIU nor the supervisory authorities have issued any guideline to financial institutions on } \\
\text { the designation of a compliance officer or on the implementation of other internal measures, } \\
\text { although the Code of Banking Practice by Bankers' Association has a provision to that effect. } \\
\text { Neither the FIU nor the supervisory authorities have issued any guideline to financial institutions on } \\
\text { the screening of employees. } \\
\text { The FTRA should require the designation of a compliance officer. }\end{array}$ \\
\hline \multicolumn{2}{|c|}{$\begin{array}{l}\text { Principle 1. Legal Requirements for Financial Service Providers (FSP) } \\
\text { 1e. Sanctions } \\
\text { Adequate sanctions should be provided for failure to comply with any of the requirements, and one or more authorized } \\
\text { government officials should have jurisdiction to enforce compliance with the above criteria by all covered persons. }\end{array}$} \\
\hline Description & $\begin{array}{l}\text { The FTRA has provided adequate criminal sanctions for noncompliance with the AML } \\
\text { requirements. Those sanctions are to be enforced by the public prosecutor's office. } \\
\text { With respect to administrative sanctions, the RBV has the power to issue 'cease and desist' orders to } \\
\text { onshore banks under section } 45 \text { of the Financial Institutions Act of } 1999 \text {, which allows the RBV to } \\
\text { require banks from ceasing any "unsound or unsafe practice in the conduct of its business." This } \\
\text { could include practices not in accordance with the AML requirements. Under section } 17 \text { of the } \\
\text { Banking Act, the VFSC may require an offshore bank to take corrective measures, but only after its } \\
\text { examination of the institution. }\end{array}$ \\
\hline
\end{tabular}




\begin{tabular}{|c|c|}
\hline & $\begin{array}{l}\text { Section 13(1) (c) of the FTRA provides the FIU with the power to investigate to ensure compliance } \\
\text { with the Act; and section } 13 \text { (3) gives the FIU a further power to enter the premises of financial } \\
\text { institutions to ensure compliance with identification and record-keeping requirements. } \\
\text { The RBV and the VFSC have the power to conduct on-site examinations with respect to domestic } \\
\text { and offshore banks and insurers. } \\
\text { The inspector of trust companies has some supervisory powers over trust companies, pursuant to the } \\
\text { Trust Companies Act. } \\
\text { Under the FTRA, the FIU is authorized to enforce the AML requirements for other service } \\
\text { providers. }\end{array}$ \\
\hline Assessment & Largely complaint \\
\hline Comments & $\begin{array}{l}\text { The FIU has wide powers to investigate to ensure compliance. The specific powers given to the FIU } \\
\text { in the FTRA to enter the premises to ensure compliance are limited to customer identification and } \\
\text { record-keeping. It does not extend to enforcing compliance with suspicious-transaction-reporting } \\
\text { obligations. However, the FTRA is unclear as to whether a search warrant is required before access } \\
\text { to the records of financial institutions can be gained by the FIU. } \\
\text { Another limitation in the FTRA is that protection from liability for financial institutions for } \\
\text { disclosure of information does not extend to disclosures made pursuant to such examinations. }\end{array}$ \\
\hline \multicolumn{2}{|c|}{$\begin{array}{l}\text { Principle 2. Integrity Standard } \\
\text { Laws should be adopted to prevent criminals and criminal organizations from controlling regulated financial } \\
\text { institutions. Laws should be adopted to ensure that shell corporations, trust and company service providers, charitable or } \\
\text { not-for-profit foundations, or other similar entities are not used for criminal purposes. }\end{array}$} \\
\hline Description & $\begin{array}{l}\text { In the domestic banking sector, sections } 13 \text { and } 14 \text { of the Financial Institutions Act provide criteria } \\
\text { for the issuance of banking licenses, which include a character test of the substantial shareholders, as } \\
\text { well as the management. In addition, section } 42 \text { of the Act bars any person who has been convicted } \\
\text { of an offence involving dishonesty from being a director, manager, secretary, or other officer of a } \\
\text { bank. } \\
\text { In the offshore banking sector, the Banking Act does not explicitly provide a fit-and-proper test, but } \\
\text { section } 9 \text { bars any person who has been convicted of an offence involving dishonesty from being a } \\
\text { director, manager, secretary, or other officer of a bank. As a matter of practice, the VFSC carries out } \\
\text { fit-and-proper checks when licensing offshore banks. } \\
\text { In the domestic insurance sector, section } 6(3) \text { of the Insurance Act empowers the minister to refuse } \\
\text { registration of a local insurer if any officer of the insurer is not a fit-and-proper person. } \\
\text { With respect to entities susceptible to being used as conduits for criminal proceeds or the financing } \\
\text { of terrorism, regulations under the Charitable Associations Act nullify a certificate of incorporation } \\
\text { granted to a terrorist entity. }\end{array}$ \\
\hline Assessment & Materially noncompliant \\
\hline Comments & $\begin{array}{l}\text { Other than domestic banking, the rest of the financial sector is either under lax regulatory regime or } \\
\text { under no government supervision. } \\
\text { For certain FSPs under government licensing, such as offshore banks and insurers, the licensing } \\
\text { requirement does not specifically refer to a fit-and-proper test. In the offshore banking sector, the } \\
\text { Banking Act gives the minister a discretionary power to grant an offshore banking license. The Act } \\
\text { has no provision for a fit-and-proper test for significant shareholders, directors, or management or } \\
\text { for a significant ownership change. } \\
\text { For all sectors, there is also no statutory fit-and-proper requirement for significant shareholders, } \\
\text { directors, and management as an ongoing requirement, except that a change in ownership of a trust } \\
\text { company requires the minister's approval. Since the mission's visit, the RBV has issued a new }\end{array}$ \\
\hline
\end{tabular}




\begin{tabular}{|c|c|}
\hline & $\begin{array}{l}\text { prudential guideline in relation to the fit-and-proper requirements for directors and managers of } \\
\text { domestic banks. } \\
\text { Other FSPs are not regulated by the government and are not required to obtain a government license. } \\
\text { With respect to international companies registered under the International Companies Act, the } \\
\text { registration authority (the VFSC) has no power to obtain, at the time of registration, such } \\
\text { information as names of directors, shareholders or the share structure of a company. } \\
\text { The government should introduce statutory fit-and-proper tests for directors, managers, and } \\
\text { significant shareholders at the time of licensing of all financial service providers, and when } \\
\text { ownership changes. In addition, the fit-and-proper test should be made an ongoing requirement. }\end{array}$ \\
\hline \multicolumn{2}{|c|}{$\begin{array}{l}\text { Principle 3. Criminalization of ML and FT } \\
\text { Laws should provide for the criminalization of ML and FT as serious offences, and ML should extend to the proceeds } \\
\text { of all serious offences, including FT, with provision for proportionate and dissuasive sanctions, including loss of } \\
\text { authority to do business. }\end{array}$} \\
\hline Description & 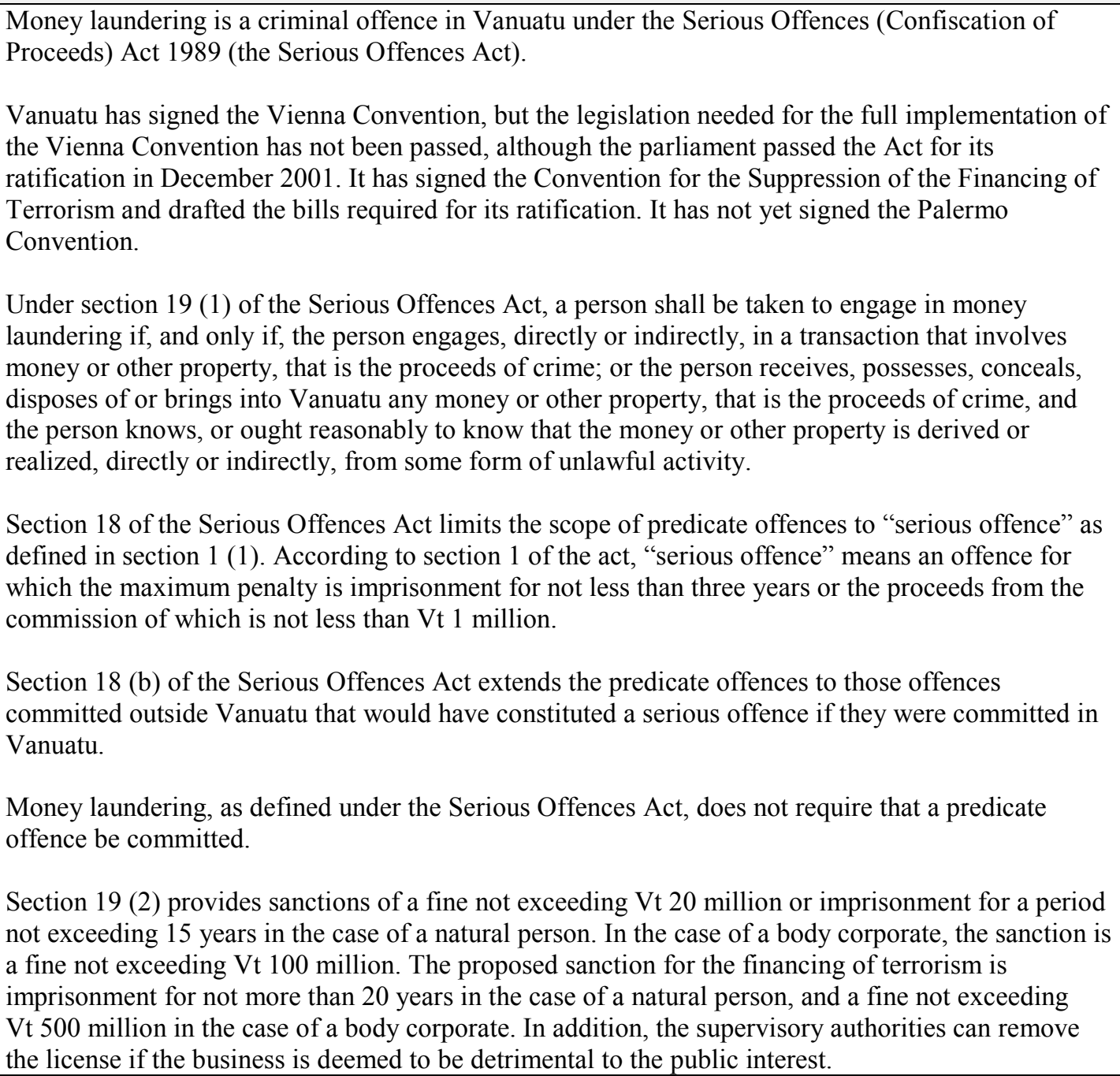 \\
\hline Assessment & Materially noncompliant \\
\hline Comments & $\begin{array}{l}\text { The three conventions have not been ratified and, as a consequence, there is no requirement that laws } \\
\text { be passed to implement the provisions of the Conventions. This significantly weakens the AML/CFT } \\
\text { framework in Vanuatu. The financing of terrorism has not been criminalized but the government has } \\
\text { recently proposed an amendment to the Serious Offences Act to criminalize financing of terrorism as } \\
\text { one of the serious offences. }\end{array}$ \\
\hline
\end{tabular}




\begin{tabular}{|c|c|}
\hline & $\begin{array}{l}\text { tion of Proceeds of Crime or Assets Used to Finance Terrorism } \\
\text { in criminal cases for the confiscation of assets laundered or intended to be laundered, the proceeds } \\
\text { ices, assets used for FT, or the instrumentalities of such offences ("assets subject to confiscation"), } \\
\text { protect the rights of bona fide third parties. }\end{array}$ \\
\hline Description & $\begin{array}{l}\text { Confiscation is conviction-based. The Serious Offences Act provides for the issuing of confiscation } \\
\text { orders where a person is convicted of a serious offence. } \\
\text { In section } 4 \text { (1) of the Serious Offences Act, "confiscation orders" are construed as orders to pay to } \\
\text { the government pecuniary penalty of such an amount as it thinks fit, but not exceeding the value of } \\
\text { the profits from serious offences. } \\
\text { Parts } 3 \text { to } 5 \text { of the Serious Offences Act provide for restraining orders in respect of domestic and } \\
\text { foreign serious offences and give authority for using production orders and search warrants in } \\
\text { respect of property-tracking documents. However, the production orders are not available for } \\
\text { bankers' books. The Act also provides for the enforcement of foreign confiscation, restraining, and } \\
\text { production orders. } \\
\text { An application for a restraining order may be made ex parte to the supreme court when a person has } \\
\text { been or is about to be charged with a serious offence and the defendant has received profits from the } \\
\text { commission of the offence. The restraining order can relate to the property of the defendant or } \\
\text { property received in connection with, or derived from, the offence and held by a person other than } \\
\text { the defendant. Once a confiscation order has been made, the property restrained can be used to } \\
\text { secure payment. } \\
\text { The Schedule to the Serious Offences Act requires that, when the value of the proceeds of the } \\
\text { serious offences are to be assessed by the court, an interest held by a person other than the defendant } \\
\text { in the relevant property shall be taken into account. Protection of bona fide third parties is provided } \\
\text { under common law for confiscation orders. } \\
\text { Section } 22 \text { of the Serious Offences Act provides for production orders under which a person } \\
\text { convicted of a serious offence is ordered to produce property-tracking documents to a police officer. } \\
\text { The Criminal Procedure Code provides for powers of search and seizure of property during } \\
\text { investigations and the power to require witnesses to be examined. These powers can be exercised for } \\
\text { money-laundering investigations. } \\
\text { Procedures for the protection of bona fide third parties in relation to restraining orders are provided } \\
\text { for in the Serious Offences Act. Under common law the government has authority to void illegal } \\
\text { contracts. }\end{array}$ \\
\hline & Materially noncompliant \\
\hline Cor & $\begin{array}{l}\text { There is no power to directly confiscate the proceeds of crime, instrumentalities, and property used } \\
\text { in the commission of the crime. The Serious Offences Act construes "confiscation orders" as orders } \\
\text { to pay to the government pecuniary penalty of such an amount as it thinks fit, but not exceeding the } \\
\text { value of the profits from serious offences. } \\
\text { The definition of proceeds of crime for purposes of confiscation is limited. } \\
\text { The Serious Offences Act does not also provide for the power to freeze transactions and accounts } \\
\text { when a money laundering offence is suspected. } \\
\text { Production orders in the Act do not extend to bankers' books. } \\
\text { The government has no specific authority to void contracts or render them unenforceable where } \\
\text { parties to the contract knew or should have known that, as a result of the contract, the authorities } \\
\text { would be prejudiced in their ability to recover financial claims resulting from the operation of the }\end{array}$ \\
\hline
\end{tabular}




\section{\begin{tabular}{|l|l}
\hline & Serious Offences Act.
\end{tabular}}

Principle 5. Processes for Receiving, Analyzing, and Disseminating Disclosures of Financial Information and Intelligence.

An FIU should be established that meets the Egmont Group definition that is responsible for receiving, analyzing, and disseminating disclosures of financial and other relevant information and intelligence concerning suspected ML or FT activities. The FIU should be empowered to receive information necessary for the discharge of its functions, and to exchange information domestically or internationally. The FIU should have additional responsibilities, in particular to conduct research and provide training.

\begin{tabular}{l|l} 
Description & Part 4 of the FTRA has established an FIU within the State Law Office, which enjoys independence
\end{tabular} from outside influence. The FIU's functions are to:

- $\quad$ receive suspicious transaction reports given by financial institutions;

- disseminate suspicious transaction reports;

- $\quad$ conduct investigations to ensure compliance with the FTRA;

- receive information from domestic and foreign regulatory or law enforcement bodies in relation to the investigation or prosecution of money laundering;

- $\quad$ issue guidelines regarding transaction record-keeping and reporting obligations; and

- $\quad$ provide training programs for financial institutions about record-keeping and reporting.

\section{Obligations}

The Vanuatu FIU is not mandated to analyze STRs. Determination of the presence of possible money-laundering activities would be carried out by the police and the public prosecutor's office.

Section 5 of the FTRA requires financial institutions to report suspicious transactions involving money-laundering activities. The same section also requires a reporting financial institution to provide the FIU with any further information requested by the FIU in relation to the suspicious transaction report made. The government has proposed an amendment to the FTRA to expand the scope of STRs to include those transactions suspected to involve activities linked to the financing of terrorism.

The Schedule to the FTRA specifies the details to be included in suspicious transaction reports. In addition, the guidelines issued by the FIU set out reporting procedures.

Section 13 (d) of the FTRA permits the FIU to receive information from the public prosecutor's office, the RBV, the VFSC, and the Vanuatu Police Force. So far, there have been no cases where the FIU has, in fact, received information from those agencies. There is no gateway for the VFSC to actually share information.

Under section 13 (1) (b) of the FTRA, the FIU is authorized to give copies of suspicious transaction reports to the public prosecutor's office and, if appropriate, other relevant authorities. Section 15 of the FTRA requires the authorized government official to keep strictly confidential the information obtained under the act. However, many of the STRs so far filed have not yet been sent to the relevant authorities.

Section 13 (1)(e) of the FTRA provides the FIU with the authority to issue guidelines to financial institutions in relation to transaction record-keeping and reporting obligations. The FIU has issued such guidelines with a detailed list of suspicious transaction examples.

Under section 13 (3) of the FTRA, a member of the FIU is authorized to enter the premises of any financial institution during ordinary business hours so as to inspect any records kept by the institution. 


\begin{tabular}{|c|c|}
\hline & $\begin{array}{l}\text { In the case of failure by financial institutions to comply with their reporting obligations, the FIU has } \\
\text { the power to investigate and could request the public prosecutor's office to bring a criminal charge } \\
\text { or, if the relevant institutions are supervised by a government agency, request the agency to take } \\
\text { administrative sanctions. So far, there have been no such cases. } \\
\text { Under section } 13 \text { (1)(b) of the FTRA, the FIU is authorized to give copies of STRs to a law } \\
\text { enforcement agency or a supervisory body outside Vanuatu if the attorney general considers it } \\
\text { appropriate. The State Law Office has not yet defined "appropriate" conditions for the supply of } \\
\text { STRs, although such determination can be made on a "case-by-case" basis. } \\
\text { Under section } 13 \text { (1)(d) of the FTRA, the FIU is also permitted to receive from foreign agencies } \\
\text { information related to money laundering or the enforcement of the Serious Offences Act. } \\
\text { The FIU is not specifically authorized in the FTRA to enter into agreements/memoranda of } \\
\text { understanding (MOU) with foreign authorized government officials on the exchange of information } \\
\text { related to money laundering. However, the minister of internal affairs has signed an MOU with } \\
\text { Australia. } \\
\text { The FIU, which was established in the State Law Office, has two part-time staff, both of whom are } \\
\text { legally qualified. } \\
\text { Section } 15 \text { of the FTRA requires the officers of the FIU and relevant agencies to keep confidential } \\
\text { any information contained in an STR or provided under the act. }\end{array}$ \\
\hline Assessment & Materially noncompliant \\
\hline Comments & $\begin{array}{l}\text { The FTRA has no specific provision giving the FIU power to analyze suspicious transactions. } \\
\text { Although a director or officer at a domestic bank is prohibited from authorizing suspicious } \\
\text { transactions under section } 53 \text { of the Financial Institutions Act, the Vanuatu FIU itself is not provided } \\
\text { with the authority to freeze or block transactions or accounts suspected to involve money laundering } \\
\text { or the financing of terrorism. } \\
\text { Although under the FTRA the FIU can require a financial institution to provide additional } \\
\text { information related to a suspicious transaction report that it has filed, there is legal uncertainty, in the } \\
\text { case of an international business company's account, as to whether the FIU has the power to obtain } \\
\text { relevant information, such as details of the beneficial ownership, from that institution without a court } \\
\text { order. } \\
\text { The small size and part-time nature of the FIU staff limits its capability to carry out its functions, } \\
\text { especially in ensuring compliance with the FTRA by financial institutions through on-site visits, } \\
\text { issuing guidelines, and providing training programs for financial institutions. } \\
\text { Due to its short history, the FIU has not yet developed internal rules and procedures for carrying out } \\
\text { its functions, such as receiving STRs and requesting additional information in connection with } \\
\text { submitted STRs, disseminating copies of STRs, and visiting financial institutions, etc. } \\
\text { The FIU and its information are not protected from legal suit and process. The FIU has no specific } \\
\text { power to enter into an MOU. The FIU needs more manpower to carry out its functions. } \\
\text { The legal uncertainty with respect to the FIU's investigative power to ensure compliance by } \\
\text { financial institutions needs to be cleared, if necessary, through an amendment to the FTRA. } \\
\text { Banking secrecy should be specifically overridden for disclosures under the FTRA so that there is no } \\
\text { ambiguity. }\end{array}$ \\
\hline
\end{tabular}




\begin{tabular}{|c|c|}
\hline \multicolumn{2}{|c|}{$\begin{array}{l}\text { Principle 6. International Cooperation in AML/CFT Matters } \\
\text { Laws should permit bilateral and multilateral cooperation, and the provision of mutual legal assistance (including } \\
\text { exchange of information, investigation, prosecution, seizure and forfeiture actions, and extradition) in AML/CFT } \\
\text { matters based on accepted international practices. }\end{array}$} \\
\hline Description & $\begin{array}{l}\text { The Mutual Assistance in Criminal Matters Act and the Serious Offences Act are the basis for } \\
\text { international judicial cooperation. The attorney general is designated as the central authority in } \\
\text { granting requests for mutual assistance and requiring government agencies to assist in investigations, } \\
\text { evidence collection, enforcing restraint orders, and confiscation of crime proceeds. Assistance can be } \\
\text { given to commonwealth countries and, in the case of noncommonwealth countries, assistance can be } \\
\text { provided if there is a treaty. } \\
\text { Parts } 3 \text { and } 4 \text { of the Mutual Assistance in Criminal Matters Act have provisions for assistance in } \\
\text { obtaining evidence, locating or identifying persons, obtaining an article by search and seizure, } \\
\text { arranging attendance of persons, transferring a prisoner, serving documents, tracing property, and } \\
\text { obtaining a restraining order. Sections } 15,16,25 \text {, and } 28 \text { of Serious Offences Act provide for the } \\
\text { issuance of confiscation orders, restraining orders, production orders and search warrants, } \\
\text { respectively, when requested in accordance with the Mutual Assistance in Criminal Matters Act. } \\
\text { The commission of a predicate offence is not a prerequisite to money laundering, as defined under } \\
\text { the Serious Offences Act. Mutual assistance may be provided even when an individual is charged } \\
\text { with money laundering only. Assistance can be given even where there are different standards on } \\
\text { intentional elements. Dual criminality is a requirement before assistance can be given. } \\
\text { Money laundering has not been included in the list of extraditable offences in the Extradition Act. } \\
\text { However, if a commonwealth country and Vanuatu are signatories to an international convention } \\
\text { that requires extradition for money laundering, then extradition is possible. In such a case, no } \\
\text { bilateral treaty is required. Extradition is available for noncommonwealth countries only if there is a } \\
\text { treaty. No treaties have been signed. }\end{array}$ \\
\hline Assessment & Largely compliant. \\
\hline Comments & $\begin{array}{l}\text { The government does not have a policy on asset sharing and, therefore, any assets found to be the } \\
\text { proceeds of illicit activity by a Vanuatu court would become the property of the government. Money } \\
\text { laundering is not listed as one of the extraditable offences. For noncommonwealth countries, no } \\
\text { treaties have been signed. }\end{array}$ \\
\hline \multicolumn{2}{|c|}{ Principle 7. Controls and Monitoring of Cash Transactions (For Information Only, Not Assessment) } \\
\hline $\begin{array}{l}\text { Description of } \\
\text { controls on the } \\
\text { import and } \\
\text { export } \\
\text { of bank notes }\end{array}$ & There is no government control on the import and export of bank notes. \\
\hline $\begin{array}{l}\text { Description of } \\
\text { procedures for } \\
\text { monitoring and } \\
\text { recording cross- } \\
\text { border } \\
\text { movements of } \\
\text { large amounts } \\
\text { of cash }\end{array}$ & Currently, there is no reporting requirement for cross-border movement of large amounts of cash. \\
\hline $\begin{array}{l}\text { Description of } \\
\text { factors which } \\
\text { influence the } \\
\text { use of cash in } \\
\text { transactions }\end{array}$ & $\begin{array}{l}\text { In most business transactions, large amounts of cash are rarely used in Vanuatu and, if used, will } \\
\text { usually attract attention. The ratio of cash to nominal GDP has been steadily declining for the last } \\
\text { few years from } 7.5 \text { percent in } 1998 \text { to } 6.1 \text { percent in } 2001 \text {. }\end{array}$ \\
\hline
\end{tabular}




\title{
Part 2: AML/CFT Elements in the Prudentially-Regulated Financial Sectors
}

\section{Module 1-AML/CFT Core Criteria for Prudentially-Regulated Financial Sectors}

\author{
Table 8. Detailed Assessment of AML/CFT Core Criteria for Prudentially-Regulated Sectors
}

\begin{tabular}{|c|c|}
\hline \multicolumn{2}{|c|}{$\begin{array}{l}\text { Principle 1. Organizational and Administrative Arrangements } \\
\text { The supervisor/regulator monitors the prevention and detection of ML offences, as well as for appropriate reporting } \\
\text { of suspected money-laundering activities. The supervisor/regulator determines that regulated entities have in place } \\
\text { policies and procedures that are adequate to deter improper use of the regulated entities by criminal elements. The } \\
\text { supervisor/regulator promotes high ethical and professional standards by regulated entities. }\end{array}$} \\
\hline Description & $\begin{array}{l}\text { The FTRA has introduced AML requirements, including the development of internal procedures } \\
\text { by financial institutions for the prevention of money laundering. The Act gives the FIU the } \\
\text { authority to conduct investigations to ensure compliance with the Act by financial institutions. } \\
\text { The RBV issued a directive on the prevention of money laundering in July 2000, and another on } \\
\text { the suppression of terrorist financing in March } 2002 \text {. The VFSC also issued practice notes on } \\
\text { anti-money-laundering requirements in October } 2001 \text {. } \\
\text { The FTRA provides sanctions for noncompliance with the requirements, which are to be enforced } \\
\text { by the public prosecutor's office. } \\
\text { The FIU is given a function to provide training programs for financial institutions about } \\
\text { transaction record-keeping and reporting obligations. Since its inception, the FIU has organized a } \\
\text { couple of seminars on the prevention of money laundering. } \\
\text { Neither the FTRA nor any other legislation makes any explicit reference to the role of the } \\
\text { supervisory agencies (the RBV, in the case of onshore banks; the VFSC, in the case of offshore } \\
\text { banks and insurers; and the inspector of trust, in relation to trust companies) in enforcing AML } \\
\text { obligations. } \\
\text { Domestic banks have in place internal procedures in relation to AML measures. }\end{array}$ \\
\hline Assessment & Materially noncompliant \\
\hline Comments & $\begin{array}{l}\text { The FIU has not yet carried out any on-site inspection to verify the compliance with AML } \\
\text { requirements, due to the lack of resources, as well as legal uncertainty regarding its investigative } \\
\text { power and the secrecy provisions in the Companies Act and the International Companies Act. } \\
\text { The RBV has the power to carry out on-site examinations and to issue 'cease and desist' orders } \\
\text { under the Financial Institution Act. However, it has not yet looked into compliance with the AML } \\
\text { requirements during its on-site examinations, which have concentrated on the credit quality of } \\
\text { banks, in line with the procedures described in the inspection manual, which does not make } \\
\text { reference to the prevention of money laundering. Some banks have taken the view that the records } \\
\text { of individual depositors, especially for international companies and offshore banks, are protected } \\
\text { under the secrecy provisions of the International Companies Act and Companies Act respectively. } \\
\text { However, it is the RBV's intention to undertake on-site visits that would include the liability side } \\
\text { of banks' balance sheets. Subsequent to the mission, the RBV has agreed that the members of the } \\
\text { FIU can accompany the RBV during on-site inspections for the purposes of training and ensuring } \\
\text { compliance with the FTRA. } \\
\text { In the offshore banking sector, the VFSC has the power to conduct on-site examinations and } \\
\text { section } 17 \text { of the Banking Act provides it with the authority to require an offshore bank to take } \\
\text { corrective measures after its examination of the bank. The VFSC has conducted } 22 \text { on-site } \\
\text { "reviews" of the local agents of offshore banks over the last two years; however, its checklist does } \\
\text { not mention any matters relating to the AML requirements. Furthermore, the lack of physical }\end{array}$ \\
\hline
\end{tabular}


presence in Vanuatu by most offshore banks severely limits the effectiveness of the VFSC's supervision.

Insurance business requires a government registration under the Insurance Act; however, there has been virtually no supervision over insurers by the Vanuatu authorities. In both the domestic and offshore insurance sector, the VFSC has the power to conduct on-site inspections under Section 39 of the Insurance Act. However, the VFSC has not performed any inspections to date and there are a number of offshore insurance companies that lack a physical presence, which again limits the effectiveness of the VFSC's supervision.

The legal uncertainty with respect to the investigative power of the FIU and the on-site supervisory power of the financial regulators vis-à-vis the secrecy provisions in the Companies Act and the International Companies Act should be clarified so as to permit the FIU and the regulators to carry out on-site verification of compliance with the AML requirements.

There is no coordination between the FIU and the financial regulators in ensuring compliance by banks and insurers.

\section{Principle 2. Customer Identification and Due Diligence}

The supervisor/regulator determines that as part of AML/CFT requirements, regulated entities have documented and enforced policies for identification of customers and those acting on their behalf. There should be a minimum set of customer identification information with additional identification requirements commensurate with the assessed risk of ML.

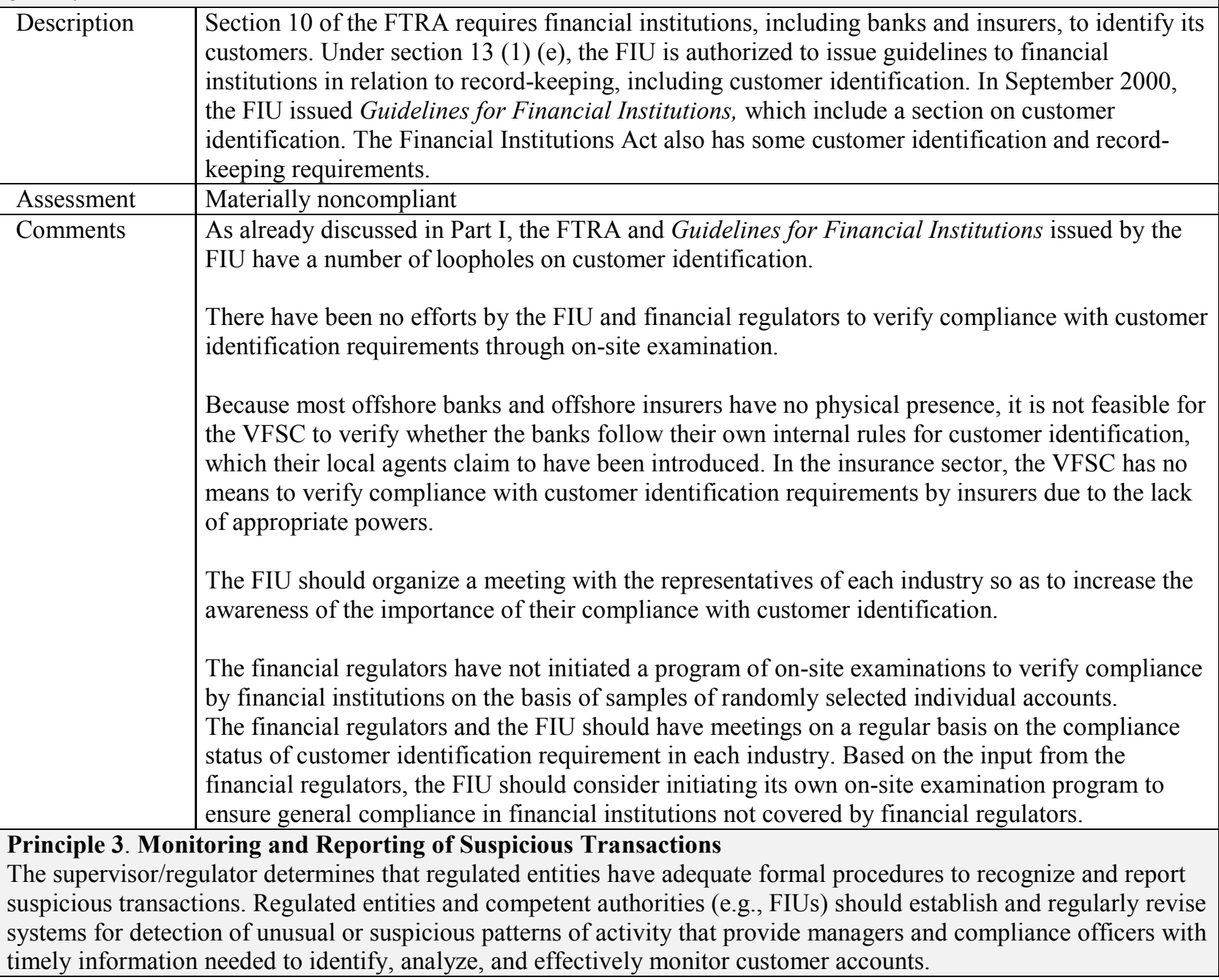




\begin{tabular}{|c|c|}
\hline Description & $\begin{array}{l}\text { Section } 5 \text { of the FTRA requires financial institutions, including banks and insurers, to report } \\
\text { suspicious transactions to the FIU as soon as possible, but no later than two working days after } \\
\text { forming the suspicion. Up to the end of } 2001 \text {, the FIU received } 110 \text { STRs; } 38 \text { were made by } \\
\text { domestic banks, } 1 \text { by the casino, and } 71 \text { by interactive gaming operators. } \\
\text { Under section } 13 \text { (c) of the FTRA, the FIU has the authority to conduct investigations to ensure } \\
\text { compliance with the Act by financial institutions. It also has the power to enter the premises of the } \\
\text { financial institutions to check their compliance with customer identification and record-keeping } \\
\text { requirements. It is also given a function to provide training programs for financial institutions } \\
\text { about reporting obligations. } \\
\text { Under section } 13 \text { (1) (e), the FIU is authorized to issue guidelines to financial institutions in } \\
\text { relation to their reporting obligations. In fact, the FIU issued a guideline on this requirement, } \\
\text { specifying how it is to be observed by financial institutions together with a detailed list of } \\
\text { examples of suspicious transactions that can be conducted through the banking sector. }\end{array}$ \\
\hline Assessment & Materially noncompliant. \\
\hline Comments & $\begin{array}{l}\text { There have been no efforts by the FIU and financial regulators to verify the compliance with } \\
\text { reporting requirements through on-site examination. } \\
\text { The regulation of the offshore banking and insurance sectors has major weaknesses. Because } \\
\text { many offshore banks have no physical presence, it is not feasible for the VFSC to verify whether } \\
\text { the banks follow their own internal rules for suspicious transaction reporting, which their local } \\
\text { agents claim to have been introduced. In the insurance sector, the VFSC has no means to verify } \\
\text { compliance with the reporting requirements due to the lack of any meaningful supervisory powers. } \\
\text { Although the Guidelines for Financial Institutions issued by the FIU provide a number of } \\
\text { examples of suspicious transactions, the government has not yet issued any regulation requiring } \\
\text { financial institutions to pay special attention to those transactions with persons in jurisdictions that } \\
\text { do not apply sufficient AML/CFT measures. The FIU should organize a meeting with the } \\
\text { representatives of each industry, so as to increase the awareness of the importance of their } \\
\text { compliance with suspicious transaction reporting. The FIU should also consider providing the } \\
\text { industries with feedback, at least on the aggregate basis, on the STRs submitted. } \\
\text { The financial regulators should initiate a program of on-site examinations to verify compliance by } \\
\text { financial institutions, including interviews with compliance officers and relevant bank employees. } \\
\text { The financial regulators and the FIU should have a meeting on a regular basis to discuss the } \\
\text { compliance status in each industry. Based on the input from the financial regulators, the FIU } \\
\text { should consider initiating its own on-site examination to ensure general compliance by financial } \\
\text { institutions. }\end{array}$ \\
\hline \multicolumn{2}{|c|}{$\begin{array}{l}\text { Principle 4. Record-keeping, Compliance, and Audit } \\
\text { The supervisor/regulator determines that regulated entities have formal record-keeping systems for customer due } \\
\text { diligence and individual transactions including a defined retention period of five years. Record-keeping procedures } \\
\text { should be regularly reviewed for compliance with applicable laws, regulations, guidance notes, and the internal } \\
\text { policies of the regulated entity. }\end{array}$} \\
\hline Description & $\begin{array}{l}\text { Sections } 9 \text { and } 11 \text { of the FTRA require financial institutions, including banks and insurers, to keep } \\
\text { transaction records and customers' records. Under section } 11 \text { (2) of the FTRA, customer } \\
\text { identification records must be kept for six years after they are obtained. Similarly, section } 9 \text { (3) of } \\
\text { the FTRA requires a financial institution to keep transaction records for six years after the } \\
\text { completion of the transaction. In addition, Section } 52 \text { of the Financial Institutions Act requires } \\
\text { onshore banks to retain all checks, bank drafts, bills of exchange, or promissory notes for six } \\
\text { years. } \\
\text { Under section } 13 \text { (1) (e), the FIU is authorized to issue guidelines to financial institutions in } \\
\text { relation to record-keeping obligation. The FIU has issued a guideline, specifying how this }\end{array}$ \\
\hline
\end{tabular}




\begin{tabular}{|c|c|}
\hline & $\begin{array}{l}\text { obligation is to be fulfilled by financial institutions. } \\
\text { Under section } 13 \text { (c) of the FTRA, the FIU has the authority to conduct investigations to ensure } \\
\text { compliance with this Act by financial institutions. It is also given a function to provide training } \\
\text { programs for financial institutions about the record-keeping obligation. There is no legislation that } \\
\text { makes any explicit reference to the role of the VFSC and the RBV in enforcing the record-keeping } \\
\text { obligation on banks and insurers. }\end{array}$ \\
\hline Assessment & Materially noncompliant \\
\hline Comments & $\begin{array}{l}\text { There have been no efforts by the FIU and financial regulators to verify compliance with the } \\
\text { record-keeping requirements through on-site examination. } \\
\text { The regulation of the offshore banking and insurance sectors has major weaknesses. Because } \\
\text { many offshore banks have no physical presence, it is not feasible for the VFSC to verify whether } \\
\text { the banks follow their own internal rules for record-keeping, which their local agents claim to } \\
\text { have been introduced. In the insurance sector, the VFSC has no means to verify compliance with } \\
\text { the record-keeping requirements by insurers. } \\
\text { The prescribed period to keep identification records under the FTRA may, in some cases, turn out } \\
\text { to be shorter than required under internationally accepted best practice, which requires five-year } \\
\text { record-keeping after the account is closed. The FIU should organize a meeting with the } \\
\text { representatives of each industry, so as to increase the awareness of the importance of their } \\
\text { compliance with record-keeping. } \\
\text { The financial regulators should initiate a program of on-site examinations to verify compliance by } \\
\text { financial institutions with the record-keeping requirements on the basis of randomly selected } \\
\text { samples of individual accounts. } \\
\text { The financial regulators and the FIU should have a meeting on a regular basis on the state of } \\
\text { compliance in each industry. Based on the input from the financial regulators, the FIU should } \\
\text { consider initiating its own on-site examination to ensure general compliance by financial } \\
\text { institutions. }\end{array}$ \\
\hline \multicolumn{2}{|c|}{$\begin{array}{l}\text { Principle 5. Cooperation Between Supervisors/Regulators and Competent Authorities } \\
\text { Competent authorities should be able to exchange information (typically through the FIU) related to suspected or } \\
\text { actual offences. }\end{array}$} \\
\hline Description & $\begin{array}{l}\text { The FTRA clearly designates the FIU as the gateway for information exchange related to } \\
\text { suspicious activities within Vanuatu and with other countries. } \\
\text { Under section } 13 \text { (1) (b), the FIU is authorized to give copies of suspicious transaction reports to } \\
\text { the public prosecutor's office and, if appropriate, other relevant authorities. Section } 15 \text { of the } \\
\text { FTRA requires the authorized government official to keep strict confidentiality of the information } \\
\text { obtained under the act. } \\
\text { Under section } 13 \text { (1) (b) of the FTRA, the FIU is authorized to give copies of STRs to a law } \\
\text { enforcement agency or a supervisory body outside Vanuatu, if the attorney general considers it } \\
\text { appropriate. The State Law Office has not yet defined "appropriate" conditions for the supply of } \\
\text { STRs. } \\
\text { Section } 55 \text { (3) of the Financial Institutions Act permits the RBV to provide information to a } \\
\text { supervisory authority in another country. There are no such provisions for the VFSC. } \\
\text { Under section } 13 \text { (1) (d), the FIU is also permitted to receive from foreign agencies information } \\
\text { related to money laundering or the enforcement of the Serious Offences Act. Section } 15 \\
\text { guarantees the same confidentiality to the information obtained under section } 13 \text { (d) as to } \\
\text { domestic STRs. }\end{array}$ \\
\hline Asse & Materially noncompliant \\
\hline
\end{tabular}




\begin{tabular}{|c|c|}
\hline Comments & $\begin{array}{l}\text { There is no legislation that authorizes the VFSC to provide any information related to offshore } \\
\text { banks and insurers to supervisory authorities in other countries. Moreover, the Companies Act } \\
\text { imposes strict secrecy provisions precluding such cooperation. }\end{array}$ \\
\hline \multicolumn{2}{|c|}{$\begin{array}{l}\text { Principle 6. Licensing and Authorizations } \\
\text { The licensing authority should take the necessary legal or regulatory measures to ensure that only qualified persons } \\
\text { control financial institutions. Measures should prevent control or acquisition of a material participation in financial } \\
\text { institutions by criminals or their confederates. }\end{array}$} \\
\hline Description & 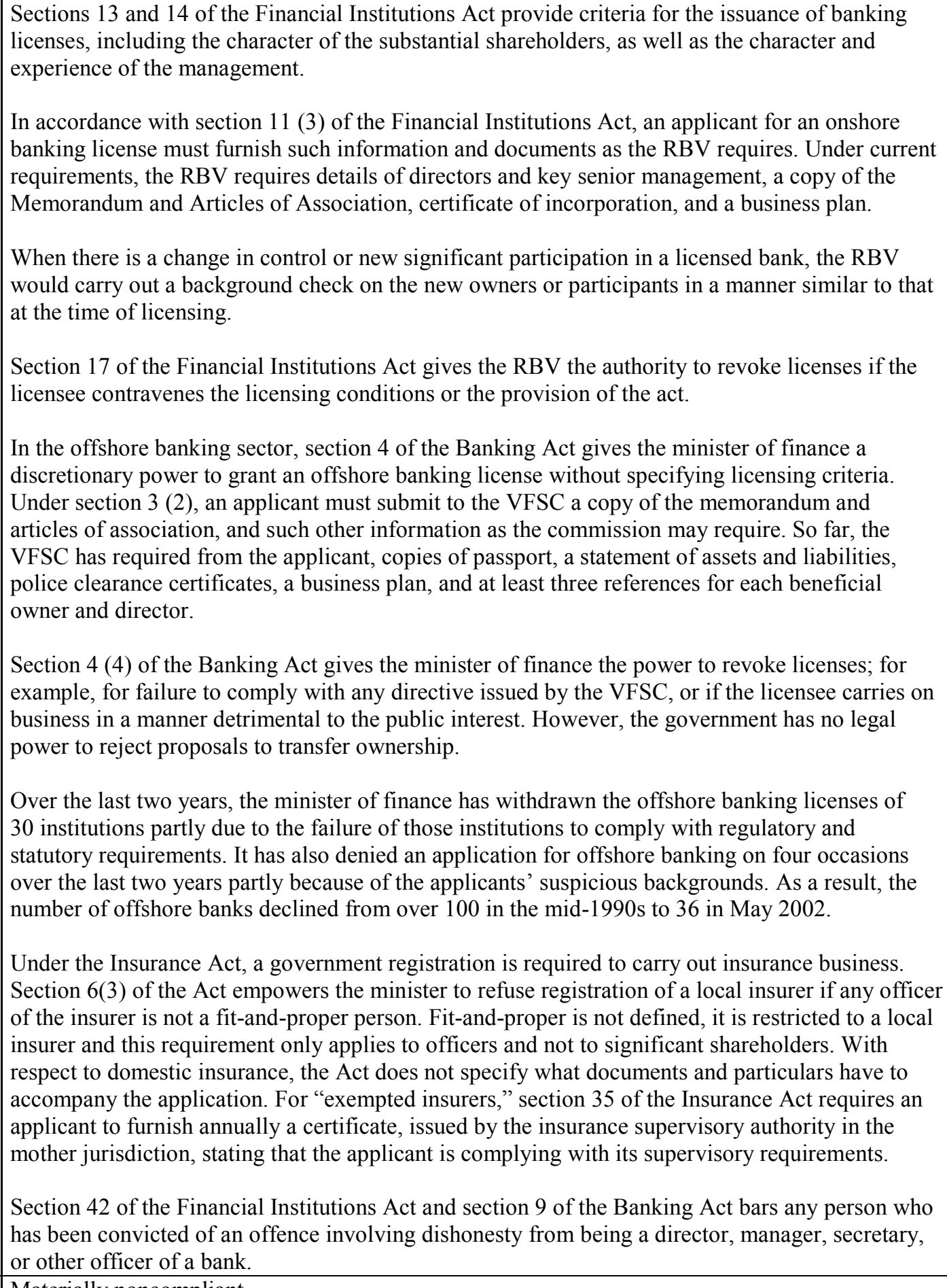 \\
\hline Asse & Materially noncompliant \\
\hline
\end{tabular}




\begin{tabular}{|l|l|}
\hline Comments & $\begin{array}{l}\text { In addition to the deficiencies mentioned in Part II on the fit-and-proper criterion in the offshore } \\
\text { banking sector, the VFSC lacks adequate means to carry out fit-and-proper tests when reviewing } \\
\text { applications for new licenses. Since many of the applicants are not banking institutions in their } \\
\text { home jurisdictions, it is extremely difficult to verify their background information with the } \\
\text { appropriate authorities in the home jurisdictions. }\end{array}$ \\
$\begin{array}{l}\text { In the insurance sector, the VFSC does not possess the capacity to review and verify license } \\
\text { applications for insurance business. }\end{array}$ \\
\hline
\end{tabular}

\section{Module 2-AML/CFT Sector-Specific Criteria for the Banking Sector}

\section{Table 9. Detailed Assessment of AML/CFT Sector-Specific Criteria for the Banking Sector}

\begin{tabular}{|c|c|}
\hline \multicolumn{2}{|c|}{$\begin{array}{l}\text { Principle 1. Organizational and Administrative Arrangements } \\
\text { No applicable banking-specific criteria. }\end{array}$} \\
\hline \multicolumn{2}{|c|}{$\begin{array}{l}\text { Principle 2. Customer Identification and Due Diligence } \\
\text { The supervisor should require that banks: (1) conduct more extensive due diligence in the case of high-risk } \\
\text { customers; (2) establish a more systematic procedure for the identification of new customers before a banking } \\
\text { relationship is established; (3) have appropriate due diligence practices for introduced business and client accounts } \\
\text { opened by professional intermediaries; (4) document and enforce policies regarding the identification of customers } \\
\text { and those who act in their behalf; (5) have appropriate identification procedures when entering into activity with } \\
\text { non-face-to-face customers; (6) refuse to enter into or continue a correspondent bank relationship with a bank } \\
\text { incorporated in a jurisdiction in which it has no physical presence and which is unaffiliated with a regulated } \\
\text { financial group; (7) pay particular attention when continuing relationships with respondent banks located in } \\
\text { jurisdictions that do not apply sufficient AML/CFT measures; (8) pay particular attention to correspondent } \\
\text { banking services; and (9) rules should require that banks include accurate and meaningful originator information } \\
\text { on funds transfers and related messages. }\end{array}$} \\
\hline Description & $\begin{array}{l}\text { The FIU and the RBV have issued guidelines on AML obligations that include account opening } \\
\text { requirements, customer identification, and verification. Neither the FIU, the RBV, nor the VFSC } \\
\text { have issued any regulations requiring financial institutions to pay special attention to high-risk or } \\
\text { non-face-to-face customers; to have specific due diligence practices for introduced business and } \\
\text { client accounts opened by professional intermediaries; to refuse to enter into or continue a } \\
\text { correspondent bank relationship with a bank incorporated in a jurisdiction in which it has no } \\
\text { physical presence and which is unaffiliated with a regulated financial group; to pay particular } \\
\text { attention when continuing relationships with respondent banks located in jurisdictions that do not } \\
\text { apply adequate AML/CFT measures; and to pay particular attention to correspondent banking } \\
\text { services. } \\
\text { When a transaction is conducted through a lawyer or an accountant who is considered another } \\
\text { "financial institution," customer identification requirement is exempted. } \\
\text { There is no legislation or regulation that specifically requires financial intermediaries to include } \\
\text { originator information and related messages on fund transfers. } \\
\text { Vanuatu banks are not suppliers of correspondent banking services. }\end{array}$ \\
\hline Assessment & ton \\
\hline \multicolumn{2}{|l|}{ Comments } \\
\hline \multicolumn{2}{|c|}{$\begin{array}{l}\text { Principle 3. Monitoring and Reporting of Suspicious Transactions } \\
\text { The supervisor/regulator should require that banks monitor its customers' accounts on a fully consolidated basis } \\
\text { worldwide. }\end{array}$} \\
\hline Description & This criterion is not applicable, as Vanuatu banks do not carry out global operations. \\
\hline \multicolumn{2}{|l|}{ Assessment } \\
\hline omments & \\
\hline
\end{tabular}




\begin{tabular}{|c|c|}
\hline $\begin{array}{l}\text { Principle } 4 . \\
\text { The supervis } \\
\text { basis, includi }\end{array}$ & $\begin{array}{l}\text { d-keeping, Compliance, and Audit } \\
\text { ulator should require that banking groups apply know-your-customer standards on a global } \\
\text { luirements for documentation, and compliance testing by the parent. }\end{array}$ \\
\hline Description & This criterion is not applicable, as Vanuatu banks do not carry out global operations. \\
\hline Assessment & \\
\hline Comments & \\
\hline $\begin{array}{l}\text { Principle } 5 . \\
\text { The host juri } \\
\text { accessing inf } \\
\text { know-your-c }\end{array}$ & $\begin{array}{l}\text { eration Between Supervisors and Competent Authorities } \\
\text { ion supervisor/regulator should ensure that home jurisdiction supervisors have no impediments in } \\
\text { tion, including from on-site examinations, needed to verify foreign operations' compliance with } \\
\text { ner policies and procedures of the home jurisdiction. }\end{array}$ \\
\hline Description & $\begin{array}{l}\text { In licensing a foreign bank, section 14(2) of the Financial Institutions Act provides that the RBV } \\
\text { must satisfy itself that there is sufficient evidence that the foreign bank is subject to } \\
\text { comprehensive supervision and regulation on a consolidated basis by its home supervisor; that } \\
\text { the foreign bank has provided written confirmation from the home supervisor that it has no } \\
\text { objection to the foreign bank carrying on banking in Vanuatu; that it is being supervised on a } \\
\text { basis consistent with the guidelines established by the Basel Committee on Banking Supervision } \\
\text { (this would include KYC principles); that the authority is willing to cooperate in the supervision } \\
\text { of the foreign bank; and that the foreign bank has provided written acknowledgement that the } \\
\text { RBV may discuss the foreign bank's conduct and status with the home supervisor. There is no } \\
\text { similar requirement in the Banking Act for offshore banks. } \\
\text { Section 55(3)(c) of the Financial Institutions Act allows for the RBV to disclose information to } \\
\text { home country supervisory authorities on the affairs and condition of a licensee. This would } \\
\text { include providing the home country supervisory authority with results of on-site inspections. } \\
\text { The VFSC only requires that, before licensing, a foreign bank provides it with a letter from the } \\
\text { supervisor of any country where it will be offering banking services confirming that it has no } \\
\text { objection and that its own regulatory requirements have been fulfilled. There is no requirement } \\
\text { that the foreign bank provides any kind of confirmation from its home supervisor. } \\
\text { The VFSC is prohibited by the secrecy provisions of the Companies Act from revealing any } \\
\text { information in relation to the affairs of an offshore bank. There are no "gateways" within either } \\
\text { the VFSC Act or the Banking Act that override these secrecy provisions. }\end{array}$ \\
\hline Assessment & Materially noncompliant \\
\hline Comments & $\begin{array}{l}\text { There is no specific requirement that the RBV ensures that the home supervisor has no } \\
\text { impediments in accessing information, including from on-site examinations, needed to verify } \\
\text { foreign branches' compliance with KYC. The only requirement is that the RBV receive a } \\
\text { confirmation at the time of licensing that the bank is being supervised consistent with Basel } \\
\text { principles, as well as that there is consolidated supervision. However, the above requirement is } \\
\text { only imposed at the time of licensing and there is no ongoing requirement. No such requirement } \\
\text { is imposed on offshore banks, whether at licensing or thereafter. The absence of any legal } \\
\text { authority for the VFSC to cooperate with overseas agencies is a material deficiency. }\end{array}$ \\
\hline & ing and Authorizations \\
\hline
\end{tabular}




\title{
Module 3-AML/CFT Sector-Specific Criteria for the Insurance Sector
}

\section{Table 10. Detailed Assessment of AML/CFT Sector-Specific Criteria for the Insurance Sector}

\begin{abstract}
Principle 1. Organizational and Administrative Arrangements
No applicable insurance sector-specific criteria.

Principle 2. Customer Identification and Due Diligence-Insurance Sector-Specific Criteria

The supervisor should: (1) determine that the insurance entity establishes to reasonable satisfaction that every verification subject relevant to the application for insurance business actually exists; (2) require that the insurance entity does not enter into a business relationship or carry out a significant one-off transaction unless it is fully implementing internal control systems; (3) require that an insurance entity carries out verification in respect of the parties entering into the insurance contract; and (4) if payments are to be made to persons other than the policyholder, the proposed recipients should be the subjects of verification.

\begin{tabular}{l|l|} 
Description & $\begin{array}{l}\text { In accordance with section 13 of the Financial Transactions Reporting Act, the FIU has issued } \\
\text { guidelines to financial institutions, including insurers, on customer verification. }\end{array}$ \\
\hline Assessment & Materially noncompliant \\
\hline Comments & $\begin{array}{l}\text { The absence of an effective regulator and the absence of a physical presence of most offshore } \\
\text { insurers makes it difficult for the FIU or the VFSC to ensure compliance with the FTRA and the } \\
\text { FIU's guidelines, to identify noncompliers and to take measures against them. The guidelines } \\
\text { issued have no insurance-specific guidance. }\end{array}$
\end{tabular}
\end{abstract}

Principle 3. Monitoring and Reporting of Suspicious Transactions-Insurance Sector-Specific Criteria The competent authority should provide guidance to identify suspicious transactions.

The supervisor should verify that insurance entities: (1) are alert to the implications of the financial flows and transaction patterns of existing policyholders; (2) are extra vigilant to the particular risks from the practice of buying and selling second hand endowment policies, as well as the use of single premium unit-linked policies; and (3) check any reinsurance or retrocession to ensure the monies are paid to bona fide reinsurance entities at rates commensurate with the risks underwritten.

\begin{tabular}{|c|c|}
\hline Description & $\begin{array}{l}\text { Part } 2 \text { of the FTRA requires insurers to monitor and report suspicious transactions. Under } \\
\text { section } 13 \text { of the Act, the FIU has the power to issue guidelines on transaction record-keeping } \\
\text { and reporting obligations. }\end{array}$ \\
\hline Assessment & Materially noncompliant \\
\hline Comments & $\begin{array}{l}\text { The absence of an effective regulator and the absence of a physical presence of most offshore } \\
\text { insurers makes it difficult for the FIU or the VFSC to ensure compliance with the FTRA and the } \\
\text { FIU's guidelines to identify noncompliers, and to take measures against them. }\end{array}$ \\
\hline \multicolumn{2}{|c|}{$\begin{array}{l}\text { Principle 4. Record-keeping, Compliance, and Audit-Insurance Sector-Specific Criteria } \\
\text { The supervisor should (1) require that the insurance entity maintain records to assess (i) initial proposal } \\
\text { documentation; (ii) post-sale records associated with the maintenance of the contract; and (iii) details of the } \\
\text { maturity processing and/or claim settlement; (2) issue guidelines and verify that if an appointed representative of } \\
\text { the insurance entity is licensed under the insurance law in the insurance supervisor's jurisdiction then the } \\
\text { insurance entity, as principal, can rely on the representative's assurance that the person will keep records on the } \\
\text { insurance entity's behalf; (3) require that if the appointed representative is not itself licensed, it is the direct } \\
\text { responsibility of the insurance company or intermediary as principal to ensure that records are kept in respect of } \\
\text { the business that such representative has introduced to it or effected on its behalf; (4) recommend that insurance } \\
\text { and reinsurance companies foster close working relationships between underwriters and claims investigators and } \\
\text { reporting systems should be in place to alert senior management and/or the board of directors if AML/CFT } \\
\text { procedures are not properly followed; and (5) have the authority to require that insurance entities have an ongoing } \\
\text { audit function of a nature and scope appropriate to the nature and scale of the business. }\end{array}$} \\
\hline Description & $\begin{array}{l}\text { Under section } 13 \text { of the Financial Transactions Reporting Act, the FIU has the power to issue } \\
\text { guidelines to financial institutions, including insurers, on transaction record-keeping and } \\
\text { reporting obligations. The Act also permits the FIU to enter the premises of any financial } \\
\text { institution to inspect any records kept by the institution. }\end{array}$ \\
\hline issessment & laterially noncompliant \\
\hline
\end{tabular}




\begin{tabular}{|l|l|}
\hline Comments & $\begin{array}{l}\text { The absence of an effective regulator and the absence of a physical presence of most offshore } \\
\text { insurers makes it difficult for the FIU or the VFSC to ensure compliance with the FTRA and the } \\
\text { FIU's guidelines, to identify noncompliers and to take measures against them. Neither the FIU } \\
\text { nor the VFSC has issued any directive or guidance as set out above. }\end{array}$ \\
\hline $\begin{array}{l}\text { Principle 5. Cooperation with Supervisors and Competent Authorities } \\
\text { No insurance sector-specific criteria }\end{array}$ \\
\hline $\begin{array}{l}\text { Principle 6. Licensing and Authorizations } \\
\text { No insurance sector-specific criteria }\end{array}$ \\
\hline
\end{tabular}

\section{Part 3: AML/CFT elements for other service providers}

Among those financial service providers not regulated prudentially, trust and company service providers are the focus of the assessment exercise in view of the global concern that offshore trusts and international companies established in the offshore sector of such jurisdictions as Vanuatu could be easily abused for ML and FT.

\section{Table 11. Detailed Assessment of AML/CFT Elements for Other Service Providers}

\begin{tabular}{|c|c|}
\hline $\begin{array}{l}\text { Principle } \\
\text { The comp } \\
\text { as for app } 1 \\
\text { requireme }\end{array}$ & $\begin{array}{l}\text { ational and Administrative Arrangements } \\
\text { rity should provide for the prevention and detection of ML and other criminal activity, as well } \\
\text { orting of suspected money-laundering activities. Legal obligations could include a training } \\
\text { g on the nature of specific activity. }\end{array}$ \\
\hline Description & $\begin{array}{l}\text { The FTRA has introduced major AML requirements on financial institutions, including a person } \\
\text { carrying on business as a trustee in respect of funds of other persons. The Act gives the FIU the } \\
\text { authority to conduct investigations to ensure compliance with this Act by financial institutions. } \\
\text { The FIU is also given a function to provide training programs for financial institutions. } \\
\\
\text { The government does not regulate company service providers, nor are they subject to the AML } \\
\text { requirements under the FTRA. While the trustees are caught within the ambit of the FTRA, } \\
\text { when a person arranges for another to act as trustee, then this is not caught within the FTRA. } \\
\text { For example, a lawyer who arranges for a trust or assists in settling a trust would not be caught. }\end{array}$ \\
\hline Assessment & Materially noncompliant \\
\hline Comments & $\begin{array}{l}\text { The FIU has not yet carried out an on-site inspection to verify compliance with the AML } \\
\text { requirements by trust companies, due to the lack of its resources, as well as the legal uncertainty } \\
\text { with respect to its investigative power and the secrecy provisions in the International } \\
\text { Companies Act. The trust company supervisor (the VFSC) has no on-site inspection powers } \\
\text { under the Trust Companies Act. } \\
\text { The Trust Companies Act provides for the appointment of an inspector of trust companies, but } \\
\text { there has been no such person appointed. It is unclear as to whether the inspector if appointed } \\
\text { would have the power to review underlying trust file unless the inspector and the FIU were to } \\
\text { enter into an arrangement whereby the inspector exercises the FIU's powers under the FTRA. }\end{array}$ \\
\hline $\begin{array}{l}\text { Principle } \\
\text { The comp } \\
\text { observed }\end{array}$ & $\begin{array}{l}\text { rer Identification and Due Diligence } \\
\text { rity should require that the legal provisions for customer due diligence are in place and } \\
\text { rate with the assessed risk of ML or FT posed by the financial service activity. There should } \\
\text { customer identification information with additional identification requirements } \\
\text { he assessed risk of ML. }\end{array}$ \\
\hline Description & $\begin{array}{l}\text { In accordance with section } 13 \text { of the FTRA, the FIU has issued guidelines to financial } \\
\text { institutions, including trust companies, on customer verification. Company service providers are } \\
\text { not subject to AML requirements. }\end{array}$ \\
\hline
\end{tabular}




\begin{tabular}{|c|c|}
\hline Assessment & Materially noncompliant \\
\hline Comments & $\begin{array}{l}\text { No regulator has been appointed for trust companies. Company service providers are not subject } \\
\text { to regulation. } \\
\text { The FIU has not met with representatives of trust companies who are subject to the FTRA. } \\
\text { The guidelines do not provide guidance to the trust companies especially in relation to who } \\
\text { should be identified when acting as a trustee. } \\
\text { Under the FTRA, there is an exemption for customer identification if a financial institution is } \\
\text { conducting business with another financial institution, which includes a trust company acting as } \\
\text { a trustee. This assumes that the trust companies have conducted their own due diligence, but } \\
\text { this will not have been subject to verification by any regulator. }\end{array}$ \\
\hline \multicolumn{2}{|c|}{ 3. Monitoring and Reporting of Suspicious Transactions } \\
\hline Description & $\begin{array}{l}\text { Part } 2 \text { of the FTRA requires trust companies to monitor and report suspicious transactions. } \\
\text { Under section } 13 \text { of the FTRA, the FIU has the power to issue guidelines on transaction record- } \\
\text { keeping and reporting obligations. }\end{array}$ \\
\hline Assessment & Materially noncompliant \\
\hline Comments & $\begin{array}{l}\text { No regulator has been appointed for trust companies. Company service providers are not subject } \\
\text { to regulation. The FIU has not ensured their compliance with the FTRA and its guidelines. }\end{array}$ \\
\hline \multicolumn{2}{|c|}{$\begin{array}{l}\text { Principle 4. Record-keeping } \\
\text { The competent authority should determine that financial service providers maintain records regarding customer } \\
\text { identification and individual transactions for a period of five years. }\end{array}$} \\
\hline Description & $\begin{array}{l}\text { Under section } 13 \text { of the Financial Transactions Reporting Act, the FIU has the power to issue } \\
\text { guidelines to financial institutions, including service providers, on transaction record-keeping } \\
\text { and reporting obligations. The Act also permits the FIU to enter the premises of any financial } \\
\text { institution to inspect any records kept by the institution. }\end{array}$ \\
\hline Assessment & Materially noncompliant \\
\hline Comments & $\begin{array}{l}\text { No regulator has been appointed for trust companies. Company service providers are not subject } \\
\text { to regulation. The FIU has not ensured their compliance with the FTRA and its guidelines. }\end{array}$ \\
\hline \multicolumn{2}{|c|}{$\begin{array}{l}\text { Principle 5. Cooperation among Competent Authorities } \\
\text { Competent authorities should be able to exchange information (typically through the FIU) related to suspected or } \\
\text { actual criminal activities. }\end{array}$} \\
\hline Description & $\begin{array}{l}\text { The FTRA clearly designates the FIU as the gateway for information exchange related to } \\
\text { suspicious activities on its own initiative or upon request. } \\
\text { Under section } 13 \text { (1) (b) of the FTRA, the FIU is authorized to give copies of STRs to a law } \\
\text { enforcement agency or a supervisory body outside Vanuatu if the attorney general considers it } \\
\text { appropriate. The State Law Office has not yet defined "appropriate" conditions for the supply of } \\
\text { STRs. } \\
\text { Meanwhile, under section } 13 \text { (1)(d), the FIU is also permitted to receive from foreign agencies } \\
\text { information related to ML or the enforcement of the Serious Offences Act. Section } 15 \text { (2)(b) } \\
\text { guarantees the same confidentiality to the information obtained under section } 13 \text { (d) as domestic } \\
\text { STRs. }\end{array}$ \\
\hline Assessment & Materially noncompliant. \\
\hline Comments & $\begin{array}{l}\text { There is no legislation that authorizes the VFSC to provide information related to trust } \\
\text { companies to the supervisory authorities in other countries. Also, since company service } \\
\text { providers are not regulated by the government, the exchange of information related to those } \\
\text { service providers is not feasible. }\end{array}$ \\
\hline \multicolumn{2}{|c|}{$\begin{array}{l}\text { Principle 6. Licensing and Authorizations } \\
\text { The competent authorities that authorize the provision of financial services should take the necessary legal or } \\
\text { regulatory measures to ensure that delivery of financial services is by properly qualified persons. Measures should } \\
\text { prevent control or acquisition of a material participation in financial service provider by criminals or their }\end{array}$} \\
\hline
\end{tabular}




\begin{tabular}{|c|c|}
\hline \multicolumn{2}{|c|}{ confederates. } \\
\hline Description & $\begin{array}{l}\text { Under the Trust Company Law, a valid license is granted by the minister of finance to carry out } \\
\text { trust company business. A license application has to be accompanied, among others, by } \\
\text { evidence that the applicant has substantial and practical experience in trust business, and a } \\
\text { character reference establishing that no director or officer has a criminal record. } \\
\text { Company service providers are not required to obtain a license in order to engage in their } \\
\text { business and there is no ongoing review. }\end{array}$ \\
\hline Assessment & Materially noncompliant \\
\hline Comments & $\begin{array}{l}\text { For trust companies, there is no ongoing review to ensure that the delivery of services is by } \\
\text { properly qualified persons. }\end{array}$ \\
\hline
\end{tabular}

Table 12. Summary of Compliance with AML/CFT Principles 1/

\begin{tabular}{|c|c|c|c|c|c|}
\hline $\begin{array}{l}\text { Legal and Institutional Framework } \\
\text { Requirements }\end{array}$ & \multicolumn{4}{|c|}{ Legal } & \\
\hline Customer due diligence & \multicolumn{4}{|l|}{ 1a. } & $\begin{array}{l}\text { Materially } \\
\text { noncompliant }\end{array}$ \\
\hline Record-keeping & \multicolumn{4}{|l|}{$1 \mathrm{~b}}$. & Largely compliant \\
\hline Suspicious transactions reporting & \multicolumn{4}{|l|}{$1 \mathrm{c}}$. & Largely compliant \\
\hline AML/CFT internal controls & \multicolumn{4}{|l|}{$1 \mathrm{~d}$. } & Largely-compliant \\
\hline Sanctions & \multicolumn{4}{|l|}{ 1e. } & Largely compliant \\
\hline Integrity standards & \multicolumn{4}{|l|}{2} & $\begin{array}{l}\text { Materially } \\
\text { noncompliant }\end{array}$ \\
\hline $\begin{array}{l}\text { Criminalization of money laundering and } \\
\text { terrorism financing }\end{array}$ & \multicolumn{4}{|l|}{3} & $\begin{array}{l}\text { Materially } \\
\text { noncompliant }\end{array}$ \\
\hline $\begin{array}{l}\text { Confiscation of proceeds of crime or assets } \\
\text { used to finance terrorism }\end{array}$ & \multicolumn{4}{|l|}{4} & $\begin{array}{l}\text { Materially } \\
\text { noncompliant }\end{array}$ \\
\hline $\begin{array}{l}\text { Process for receiving, analyzing, and } \\
\text { disseminating disclosures of financial } \\
\text { information and intelligence }\end{array}$ & \multicolumn{4}{|l|}{5} & $\begin{array}{l}\text { Materially } \\
\text { noncompliant }\end{array}$ \\
\hline International cooperation in AML/CFT matters & \multicolumn{4}{|l|}{6} & Largely-compliant \\
\hline Prudentially-regulated sectors requirements & & Banking & Insurance & Securities & \begin{tabular}{|l|} 
Other Service \\
Providers
\end{tabular} \\
\hline $\begin{array}{l}\text { Organizational and administrative } \\
\text { arrangements }\end{array}$ & & $\begin{array}{l}\text { Materially } \\
\text { noncompliant }\end{array}$ & $\begin{array}{l}\text { Materially } \\
\text { noncompliant }\end{array}$ & $\begin{array}{l}\text { Not } \\
\text { assessed }\end{array}$ & $\begin{array}{l}\text { Materially } \\
\text { noncompliant }\end{array}$ \\
\hline Customer identification and due diligence & & $\begin{array}{l}\text { Materially } \\
\text { noncompliant }\end{array}$ & $\begin{array}{l}\text { Materially } \\
\text { noncompliant }\end{array}$ & $\begin{array}{l}\text { Not } \\
\text { assessed }\end{array}$ & $\begin{array}{l}\text { Materially } \\
\text { noncompliant }\end{array}$ \\
\hline $\begin{array}{l}\text { Monitoring and reporting of suspicious } \\
\text { activities }\end{array}$ & & $\begin{array}{l}\text { Materially } \\
\text { noncompliant }\end{array}$ & $\begin{array}{l}\text { Materially } \\
\text { noncompliant }\end{array}$ & $\begin{array}{l}\text { Not } \\
\text { assessed }\end{array}$ & $\begin{array}{l}\text { Materially } \\
\text { noncompliant }\end{array}$ \\
\hline Record-keeping, compliance and audit & & $\begin{array}{l}\text { Materially } \\
\text { noncompliant }\end{array}$ & $\begin{array}{l}\text { Materially } \\
\text { noncompliant }\end{array}$ & $\begin{array}{l}\text { Not } \\
\text { assessed }\end{array}$ & $\begin{array}{l}\text { Materially } \\
\text { noncompliant }\end{array}$ \\
\hline $\begin{array}{l}\text { Cooperation with regulators and competent } \\
\text { authorities }\end{array}$ & & $\begin{array}{l}\text { Materially } \\
\text { noncompliant }\end{array}$ & $\begin{array}{l}\text { Materially } \\
\text { noncompliant }\end{array}$ & $\begin{array}{l}\text { Not } \\
\text { assessed }\end{array}$ & $\begin{array}{l}\text { Materially } \\
\text { noncompliant }\end{array}$ \\
\hline Licensing and authorizations & & $\begin{array}{l}\text { Materially } \\
\text { noncompliant }\end{array}$ & $\begin{array}{l}\text { Materially } \\
\text { noncompliant }\end{array}$ & $\begin{array}{l}\text { Not } \\
\text { assessed }\end{array}$ & $\begin{array}{l}\text { Materially } \\
\text { noncompliant }\end{array}$ \\
\hline
\end{tabular}

1/ This table provides compliance ratings in terms of the sections of the assessment methodology rather than the AML/CFT standard, FATF's Forty Recommendations and the Eight Special Recommendations on Terrorist Financing. 